Prepared in cooperation with Clean Water Services

\title{
Use of Stable Isotopes of Carbon and Nitrogen to Identify Sources of Organic Matter to Bed Sediments of the Tualatin River, Oregon
}

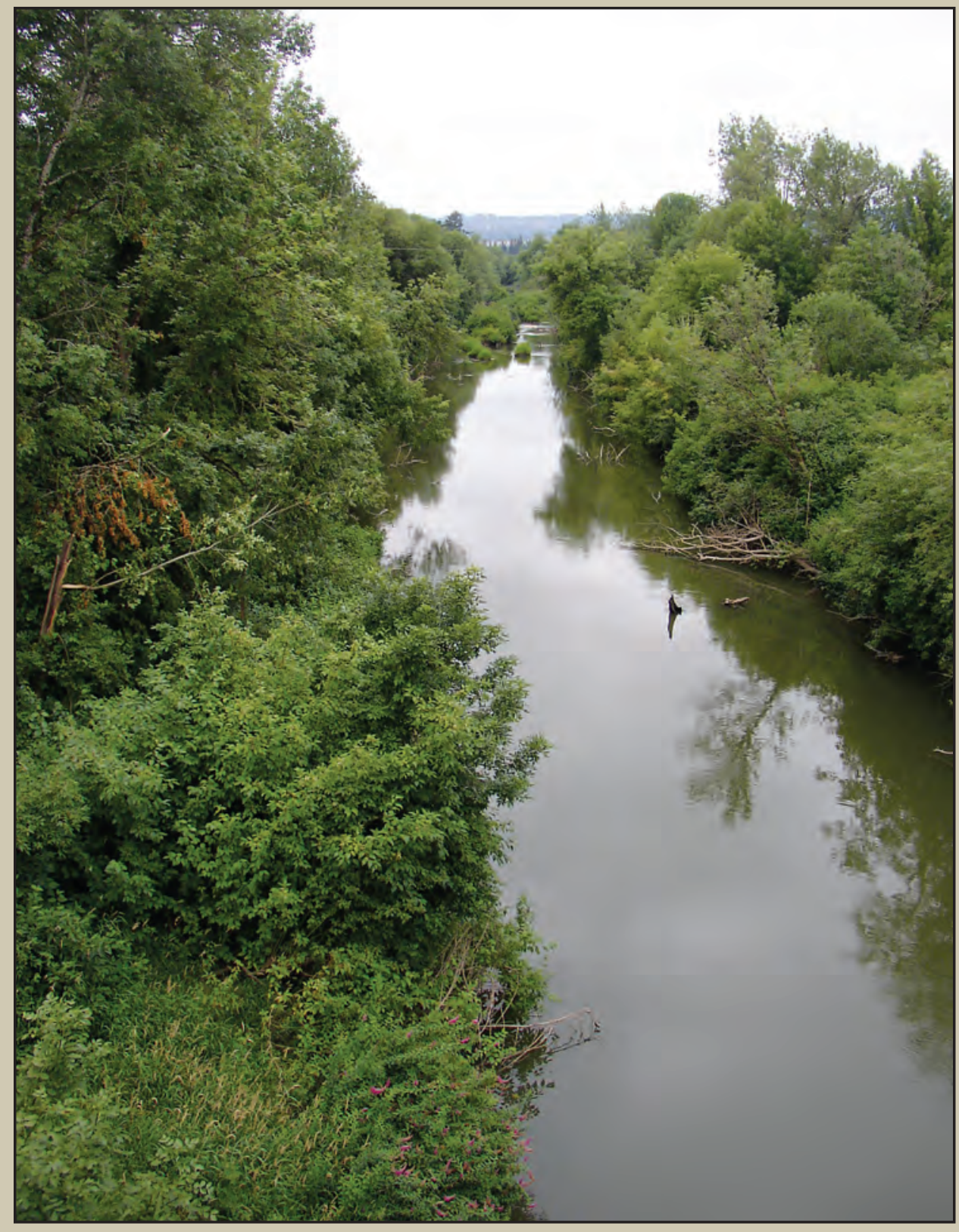

Scientific Investigations Report 2010-5154

U.S. Department of the Interior

U.S. Geological Survey 
Cover: Photograph of Tualatin River looking downstream from Farmington bridge, July 19, 2008, by Stewart Rounds, U.S. Geological Survey.

Back Cover:

Top

Photograph of Tualatin River at Lee Falls, September 24, 2001, by Stewart Rounds, U.S. Geological Survey

Middle

Photograph of the Tualatin River near Stafford Road, September 23, 2005,

by Stewart Rounds, U.S. Geological Survey

Bottom

Photograph of Rock Creek Treatment Facility, June 22, 2000, by Dennis Wentz, U.S. Geological Survey 


\section{Use of Stable Isotopes of Carbon and Nitrogen to Identify Sources of Organic Matter to Bed Sediments of the Tualatin River, Oregon}

By Bernadine A. Bonn and Stewart A. Rounds

Prepared in cooperation with Clean Water Services

Scientific Investigations Report 2010-5154 


\title{
U.S. Department of the Interior \\ KEN SALAZAR, Secretary
}

\section{U.S. Geological Survey \\ Marcia K. McNutt, Director}

\section{U.S. Geological Survey, Reston, Virginia: 2010}

\begin{abstract}
For more information on the USGS — the Federal source for science about the Earth, its natural and living resources, natural hazards, and the environment, visit http://www.usgs.gov or call 1-888-ASK-USGS

For an overview of USGS information products, including maps, imagery, and publications, visit http://www.usgs.gov/pubprod

To order this and other USGS information products, visit http://store.usgs.gov
\end{abstract}

Any use of trade, product, or firm names is for descriptive purposes only and does not imply endorsement by the U.S. Government.

Although this report is in the public domain, permission must be secured from the individual copyright owners to reproduce any copyrighted materials contained within this report.

Suggested citation:

Bonn, B.A., and Rounds, S.A., 2010, Use of stable isotopes of carbon and nitrogen to identify sources of organic matter to bed sediments of the Tualatin River, Oregon: U.S. Geological Survey Scientific Investigations Report 2010$5154,58 \mathrm{p}$. 


\section{Contents}

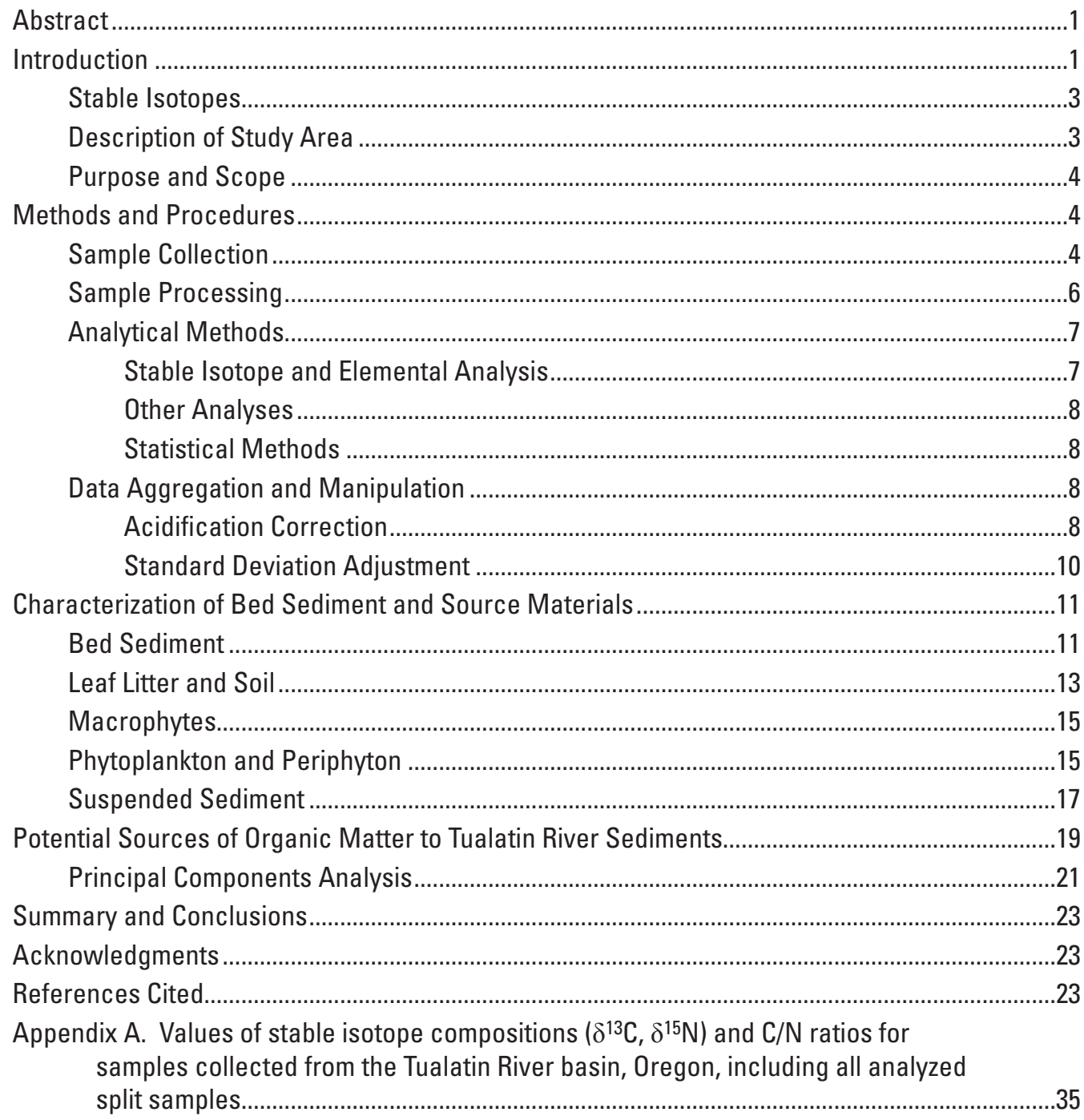




\section{Figures}

Figure 1. Map showing the Tualatin River basin in northwestern Oregon $\begin{gathered}\ldots \ldots \ldots \ldots \ldots \ldots \ldots \\ 2\end{gathered}$

Figure 2. Map showing location of sampling sites in the Tualatin River basin, Oregon $\ldots \ldots \quad 5$

Figure 3. Graphs showing regression results for acidified versus unacidified samples from the Tualatin River basin, Oregon

Figure 4. Graphs showing stable isotope results and $\mathrm{C} / \mathrm{N}$ ratios for bed sediment samples from the Tualatin River basin, showing observed ranges and outliers $\quad \ldots 12$

Figure 5. Graph showing pairwise $\delta^{13} \mathrm{C}$ differences for several sampling periods compared to results from late-summer-1999

Figure 6. Graphs showing stable isotope results for potential source materials of sedimentary organic matter with shading showing observed ranges for each type of material in the Tualatin River basin, Oregon

Figure 7. Graphs showing comparison of $\delta^{13} \mathrm{C}, \delta^{15} \mathrm{~N}$ and $\mathrm{C} / \mathrm{N}$ results for two size fractions of seston for samples from the Tualatin River basin, Oregon

Figure 8. Graphs showing stable isotope results for seston and periphyton samples from the Tualatin River basin, Oregon, with shading showing groups of

Tualatin River samples

Figure 9. Graphs showing relations between $\delta^{13} \mathrm{C}, \delta^{15} \mathrm{~N}$, and $\mathrm{C} / \mathrm{N}$ in seston samples from the Tualatin River, Oregon, show that high chlorophyll-a concentrations are associated with low $\delta^{13} \mathrm{C}$, high $\delta^{15} \mathrm{~N}$, and low $\mathrm{C} / \mathrm{N}$

Figure 10. Graphs showing stable isotope results for suspended sediment samples from the Tualatin River basin, Oregon, with shading showing groups of Tualatin River samples

Figure 11. Graphs showing $\delta^{13} \mathrm{C}, \delta^{15} \mathrm{~N}$ and $\mathrm{C} / \mathrm{N}$ values for bed sediment and several types of potential source materials from the Tualatin River basin, Oregon

Figure 12. Plots showing a comparison of $\delta^{13} \mathrm{C}, \delta^{15} \mathrm{~N}$ and $\mathrm{C} / \mathrm{N}$ for samples of bed sediment, suspended sediment, and seston from the Tualatin River basin, Oregon

Figure 13. Graphs showing $\delta^{13} \mathrm{C}, \delta^{15} \mathrm{~N}$ and $\mathrm{C} / \mathrm{N}$ values of terrestrial materials and bed sediment samples from the Tualatin River basin, Oregon

Figure 14. Graph showing results of a principal components analysis of $\delta^{13} \mathrm{C}, \delta^{15} \mathrm{~N}$, and $\mathrm{C} / \mathrm{N}$ data for samples taken from the Tualatin River basin, Oregon

\section{Tables}

Table 1. Summary of sample collection at each sampling site, Tualatin River basin, Oregon

Table 2. Relation between acidified and unacidified $\delta^{13} \mathrm{C}, \delta^{15} \mathrm{~N}$, and $\mathrm{C} / \mathrm{N}$ results for samples from the Tualatin River basin, Oregon

Table 3. Confidence intervals of sample means for samples from the Tualatin River basin, Oregon 10

Table 4. Ranges of $\delta^{13} \mathrm{C}$ and $\delta^{15} \mathrm{~N}$ values and $\mathrm{C} / \mathrm{N}$ ratios for terrestrial plant material $\ldots \ldots 13$

Table 5. Results of principal components analysis .................................. 21

Table 6. Mean values and confidence intervals of stable isotope compositions $\left(\delta^{13} \mathrm{C}, \delta^{15} \mathrm{~N}\right)$ and $\mathrm{C} / \mathrm{N}$ ratios for samples collected in the Tualatin River basin, Oregon 


\section{Conversion Factors, Datum, and Abbreviations and Acronyms}

\section{Conversion Factors}

Inch/Pound to SI

\begin{tabular}{lll}
\hline \multicolumn{1}{c}{ Multiply } & By & \multicolumn{1}{c}{ To obtain } \\
\hline foot $(\mathrm{ft})$ & 0.3048 & meter $(\mathrm{m})$ \\
mile $(\mathrm{mi})$ & 1.609 & kilometer $(\mathrm{km})$ \\
square mile $\left(\mathrm{mi}^{2}\right)$ & 2.590 & square kilometer $\left(\mathrm{km}^{2}\right)$ \\
ounce, fluid $(\mathrm{fl} . \mathrm{oz})$ & 0.02957 & liter $(\mathrm{L})$ \\
cubic foot per second $\left(\mathrm{ft}^{3} / \mathrm{s}\right)$ & 0.02832 & cubic meter per second $\left(\mathrm{m}^{3} / \mathrm{s}\right)$ \\
foot per mile $(\mathrm{ft} / \mathrm{mi})$ & 0.1894 & meter per kilometer $(\mathrm{m} / \mathrm{km})$ \\
\hline
\end{tabular}

SI to Inch/Pound

\begin{tabular}{lll}
\hline \multicolumn{1}{c}{ Multiply } & By & \multicolumn{1}{c}{ To obtain } \\
\hline centimeter $(\mathrm{cm})$ & 0.3037 & inch (in.) \\
micrometer $(\mu \mathrm{m})$ & 0.00003937 & inch (in.) \\
meter $(\mathrm{m})$ & 3.281 & foot (ft) \\
square meter $\left(\mathrm{m}^{2}\right)$ & 0.0002471 & acre \\
liter $(\mathrm{L})$ & 33.82 & ounce, fluid (fl. oz) \\
gram $(\mathrm{g})$ & 0.03537 & ounce, avoirdupois $(\mathrm{oz})$ \\
\hline
\end{tabular}

Temperature in degrees Celsius $\left({ }^{\circ} \mathrm{C}\right)$ may be converted to degrees Fahrenheit $\left({ }^{\circ} \mathrm{F}\right)$ as follows:

$$
{ }^{\circ} \mathrm{F}=\left(1.8 x^{\circ} \mathrm{C}\right)+32
$$

\section{Datum}

Horizontal coordinate information is referenced to the North American Datum of 1983 (NAD 83).

\section{Abbreviations and Acronyms}

\begin{tabular}{ll}
\hline DO & dissolved oxygen \\
PC1 & principal component 1 \\
PC2 & principal component 2 \\
PCA & principal components analysis \\
RM & river mile \\
SOD & sediment oxygen demand \\
TMDL & Total Maximum Daily Load \\
USGS & U.S. Geological Survey \\
WWTF & wastewater treatment facility \\
\hline
\end{tabular}


This page intentionally left blank. 


\title{
Use of Stable Isotopes of Carbon and Nitrogen to Identify Sources of Organic Matter to Bed Sediments of the Tualatin River, Oregon
}

\author{
By Bernadine A. Bonn and Stewart A. Rounds
}

\section{Abstract}

The potential sources of organic matter to bed sediment of the Tualatin River in northwestern Oregon were investigated by comparing the isotopic fractionation of carbon and nitrogen and the carbon/nitrogen ratios of potential sources and bed sediments. Samples of bed sediment, suspended sediment, and seston, as well as potential source materials, such as soil, plant litter, duckweed, and wastewater treatment facility effluent particulate were collected in 1998-2000.

Based on the isotopic data, terrestrial plants and soils were determined to be the most likely sources of organic material to Tualatin River bed sediments. The $\delta^{13} \mathrm{C}$ fractionation matched well, and although the $\delta^{15} \mathrm{~N}$ and carbon/ nitrogen ratio of fresh plant litter did not match those of bed sediments, the changes expected with decomposition would result in a good match. The fact that the isotopic composition of decomposed terrestrial plant material closely resembled that of soils and bed sediments supports this conclusion.

Phytoplankton probably was not a major source of organic matter to bed sediments. Compared to the values for bed sediments, the $\delta^{13} \mathrm{C}$ values and carbon/nitrogen ratios of phytoplankton were too low and the $\delta^{15} \mathrm{~N}$ values were too high. Decomposition would only exacerbate these differences. Although phytoplankton cannot be considered a major source of organic material to bed sediment, a few bed sediment samples in the lower reach of the river showed a small influence from phytoplankton as evidenced by lower $\delta^{13} \mathrm{C}$ values than in other bed sediment samples.

Isotopic data and carbon/nitrogen ratios for bed sediments generally were similar throughout the basin, supporting the idea of a widespread source such as terrestrial material. The $\delta^{15} \mathrm{~N}$ was slightly lower in tributaries and in the upper reaches of the river. Higher rates of sediment oxygen demand have been measured in the tributaries in previous studies and coupled with the isotopic data may indicate the presence of more labile organic matter in these areas. Results from this study indicate that strategies to improve oxygen conditions in the Tualatin River are likely to be more successful if they target sources of soil, leaf litter, and other terrestrially derived organic materials to the river rather than the instream growth of algae.

\section{Introduction}

Dissolved oxygen is essential to the aquatic health of many rivers and lakes, and the concentration of dissolved oxygen often is used as a water-quality standard to protect fish and aquatic life. The dissolved oxygen (DO) concentration in a waterbody is affected by many processes, such as exchange with the atmosphere (reaeration), photosynthesis by algae or aquatic plants, ammonia nitrification, respiration by algae and bacteria, and the bacterially mediated decomposition of organic matter suspended in the water column or in surficial sediments. The oxygen consumed through the decomposition of organic matter in surficial sediments is called sediment oxygen demand (SOD) and can be one of the most important loss processes for DO, particularly in shallow streams.

Low DO conditions periodically occur in the lower reaches of the Tualatin River and its tributaries in northwestern Oregon (fig. 1), especially during low-flow periods when the water is warm but algal photosynthesis is minimal. During such periods, SOD can account for a large fraction of the total DO consumed. The U.S. Geological Survey (USGS) investigated the effects of SOD in the Tualatin River, measured a median SOD rate of 2.3 grams of oxygen per square meter of sediment per day $\left(\mathrm{g} / \mathrm{m}^{2} / \mathrm{d}\right.$ ) (Rounds and Doyle, 1997), and determined that SOD and water-column oxygen demand are the largest overall sinks for DO in the Tualatin River (Rounds and others, 1999).

In response to water-quality problems in the Tualatin River, Oregon's Department of Environmental Quality in 1988 adopted a set of Total Maximum Daily Load (TMDL) regulations in an effort to restore the aesthetic qualities of the river and protect the river against low DO concentrations and high $\mathrm{pH}$ levels. The TMDLs required substantial ammonia and phosphorus reductions, which were designed to increase DO concentrations and limit the size of algal blooms during the summer months. At that time, it was assumed that algal-derived biomass settling to the river bottom was an important source of decomposable organic matter, and that limiting the size of algal blooms would not only eliminate high $\mathrm{pH}$ levels but also decrease the SOD and increase DO concentrations. That assumption was challenged by later measurements that determined that SOD rates generally were 


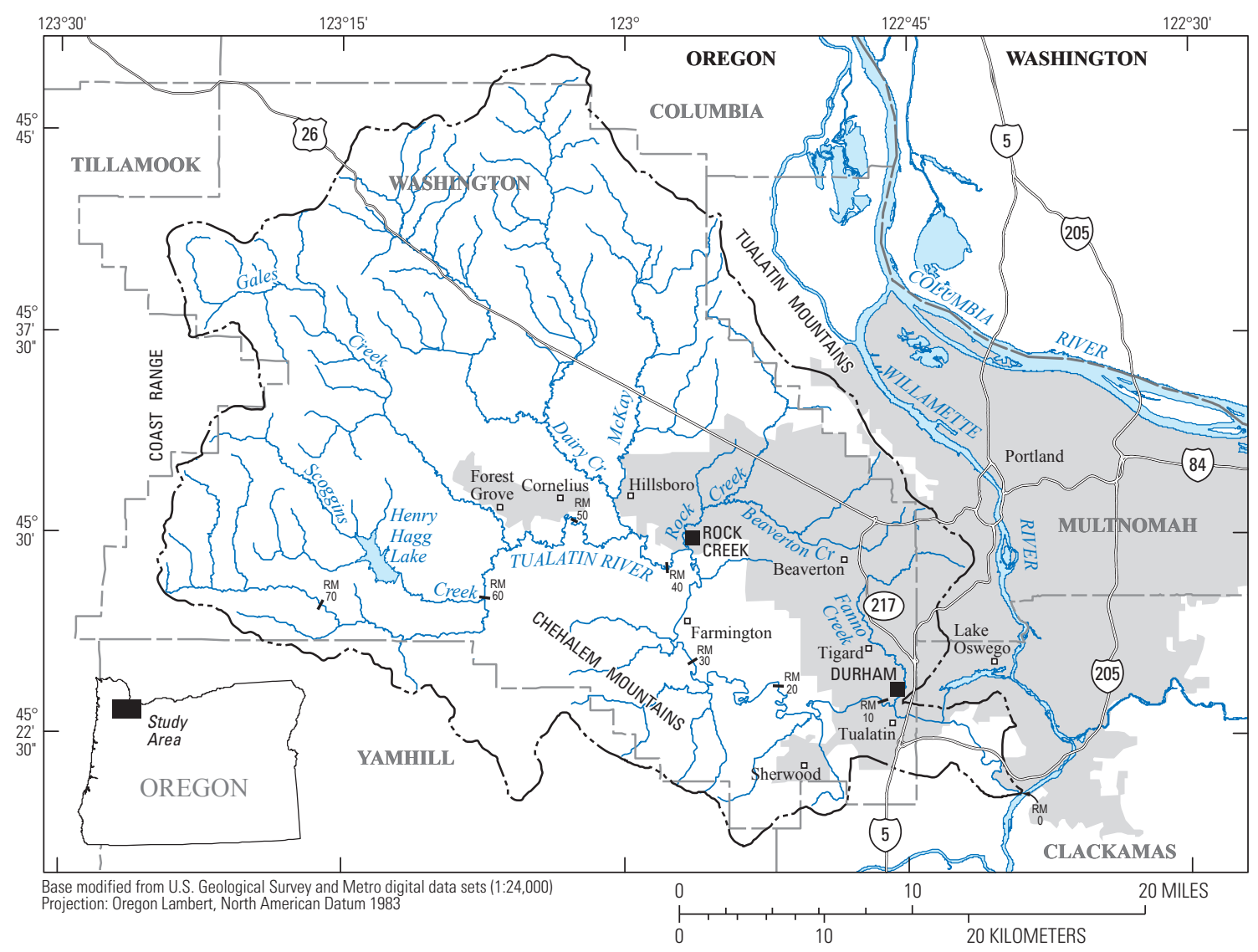

EXPLANATION

Designated Urban Growth Boundary (2001)

Basin boundary

- Wastewater Treatment Facility

Figure 1. Tualatin River basin in northwestern Oregon.

not elevated in those reaches of the river that had the largest algae populations, except at one site in the lower river where a slightly higher rate might be ascribed to enhanced deposition of algal biomass (Rounds and Doyle, 1997). Furthermore, water-quality modeling by USGS showed that even if ammonia sources were fully controlled, the Tualatin River still could be subject to periodic low-DO conditions because of DO consumption by SOD (Rounds and others, 1999). Revision of the Tualatin River TMDLs in 2001 recognized the importance of SOD and called for significant decreases (20 percent or more) in the SOD rate of the river and its tributaries through the control of settleable organic materials (Oregon Department of Environmental Quality, 2001).
In order to manage and potentially reduce the effects of SOD, it is important to determine the sources of the organic matter delivered to stream sediments. Potential sources of such organic matter include not only algae, but aquatic plants, soils, terrestrial plant material, and possibly the particulate in effluent from wastewater treatment facilities (WWTFs). Many of these materials, however, may be distinguished from one another through measurements of the content and characteristics of the carbon and nitrogen present in that organic matter. Measurements of stable isotopes of carbon and nitrogen have been used for many years to investigate the nature and sources of organic matter in freshwater systems (Middelburg and Nieuwenhuize, 1998; Finlay and Kendall, 2007). 


\section{Stable Isotopes}

An element is defined by the number of protons that it contains; for example, all carbon atoms contain six protons and all nitrogen atoms contain seven protons. Atoms of the same element, however, may contain different numbers of neutrons, which cause them to have different masses. Forms of the same element that have different masses are called isotopes; stable isotopes are forms that are not radioactive. Although isotopes vary in the number of neutrons that they contain, their chemical properties essentially are identical. Many elements of biological interest [carbon (C), nitrogen $(\mathrm{N})$, oxygen $(\mathrm{O})$, sulfur $(\mathrm{S})]$ have different isotopic forms. The relative abundances of isotopes can be measured with great precision using a mass spectrometer, and such abundances have been used to study biogeochemical cycles and ecosystem dynamics.

The use of stable isotope abundances is based on the fact that different isotopes of an element participate in the same chemical reactions, but at slightly different rates due to their different masses. Lighter isotopes typically react at a slightly faster rate, which causes the relative isotopic abundance in the reactants and products to differ. This process is called isotopic fractionation. For example, the growth of algae tends to create algal biomass that contains less of the heavier carbon-13 isotope and more of the lighter carbon-12 isotope. By examining the isotopic composition of potential source materials, it might be possible to identify the sources of organic matter to river bed sediments.

\section{Description of Study Area}

The Tualatin River basin is a $712 \mathrm{mi}^{2}$ watershed in northwestern Oregon. Encompassing most of Washington County and parts of Multnomah, Clackamas, and several other counties, the basin includes the western part of the Portland metropolitan area and was home to approximately 450,000 people at the time of this study (U.S. Census Bureau, 2000). The river begins in the forested Coast Range mountains to the west, meanders through a valley bottom farmed for a wide variety of agricultural products, and skirts the southern boundary of the urban area before joining the Willamette River upstream (south) of Portland (fig. 1).

Five major tributaries enter the Tualatin River, each of which has distinct characteristics. Scoggins Creek has most of its drainage in the Coast Range and contains the basin's only reservoir, Henry Hagg Lake, which stores water for irrigation, municipal use, and flow augmentation during summer. Gales Creek also has a significant headwater area in the Coast Range and primarily is forested (70 percent). Dairy Creek is located in the northern center of the basin and has a large area of agricultural land (50 percent) in its drainage. Rock and Fanno Creeks drain the northeastern part of the basin, and contain a substantial amount of urban land use (66 and 100 percent, respectively; data from 2001 National Land Cover Database, see Homer and others, 2007).

Streamflow in the Tualatin River reflects the regional climate, with higher flow during the winter rainy season (approximately November-April) and the lowest flow during the dry summer season (May-October). Typical peak annual flows are greater than $5,000 \mathrm{ft}^{3} / \mathrm{s}$, whereas typical summertime low flows are less than $200 \mathrm{ft}^{3} / \mathrm{s}$. Summer flows are augmented to improve water quality through releases from Henry Hagg Lake and from Barney Reservoir, a smaller storage reservoir in the adjacent Trask River basin to the west. Treated wastewater from the Rock Creek and Durham advanced WWTFs also add a substantial amount of flow to the river. During late summer, treated wastewater and reservoir releases can account for as much as 50 to 75 percent of the flow in the river (Tualatin River Flow Management Technical Committee, 2000).

The slope, width, adjacent vegetation, and substrate of the Tualatin River have an effect on the water quality of the river. In the Coast Range, the river is steep and runs over a bedrock substrate that includes several waterfalls. It is clear, cool, and well shaded, and as a result, it is well oxygenated. Where the river meets the valley bottom upstream of Gaston, its slope decreases to just more than $1 \mathrm{ft} / \mathrm{mi}$ and it begins to suspend fine particulate material as it meanders on valley sediments. The river from Gaston to river mile (RM) 30 is about $50 \mathrm{ft}$ wide and still relatively well shaded. The lack of light means that few algae grow in this reach. Near RM 30, the river transitions to a pooled reach with a slope less than $0.1 \mathrm{ft} / \mathrm{mi}$ and a width of about $150 \mathrm{ft}$, allowing solar radiation to stimulate the growth of algae. The pooled reach, with depths that often exceed $15 \mathrm{ft}$, is a depositional area that accumulates a large amount of organic-rich sediment. This reach extends downstream to RM 3.4 at the Oswego Dam, a 4-ft high concrete structure built on a shallow bedrock sill. During summer, the residence time in the pooled reach can be 10-14 days, which is sufficient time to grow a large population of phytoplankton (free-floating algae) and/or deplete a substantial amount of DO through SOD. 


\section{Purpose and Scope}

This report describes the use of carbon and nitrogen stable isotope measurements and carbon/nitrogen $(\mathrm{C} / \mathrm{N})$ ratios to identify the likely sources of organic material to bed sediments of the Tualatin River. In particular, the study addresses the following questions:

- Does bed sediment have a similar isotopic composition throughout the Tualatin River?

- Is the isotopic composition of bed sediment in the Tualatin River similar to that in the tributaries?

- What are the isotopic compositions of potential source materials of bed sediment?

- Based on isotopic composition, what source materials appear to contribute most to bed sediment, and is it likely that the contribution of algae is significant?

These questions are critical to the management of water quality in the Tualatin River basin and will help to determine the priority of various source-control efforts related to the TMDLs.

The focus of this study was on bed sediment in the lower Tualatin River where decomposing organic materials on the river bed can consume large amounts of dissolved oxygen. Sediment oxygen demand tends to be most important in the pooled reach of the river between RM 30 downstream of Farmington and RM 3.4 at the Oswego Dam because the slow travel time in this reach favors the exertion of SOD. The scope of the study, however, includes bed sediment samples from farther upstream and from Tualatin River tributaries as well as a wide range of potential source materials throughout the drainage basin. Sampled source materials included soils, leaf litter and detritus, plankton, aquatic plants, WWTF effluent particulate, and suspended sediment. To examine seasonal variations and assess interannual variability, samples were collected at different times of year between late summer of 1998 and the summer of 2000 .

\section{Methods and Procedures}

\section{Sample Collection}

A preliminary study was done in the summer of 1998 to ascertain if stable isotope analysis might be useful in identifying what materials were the primary contributors to decomposable organic material in Tualatin River bed sediment. Bed sediment, suspended sediment, and seston (suspended particulate material, including plankton and organic detritus) samples were collected at two sites in the Tualatin River. Terrestrial materials, such as leaf litter and soil, also were collected from several sites.

After the preliminary study indicated that the method might be successful in identifying the primary sources of organic matter to bed sediment, a more extensive study was designed and completed. Bed sediment, suspended sediment, and seston samples were obtained at eight sites along the Tualatin River, near the mouths of four tributaries, and from Hagg Lake during four separate sampling periods (mid-summer-1999, late-summer-1999, winter-2000, and early-summer-2000). Not every site-material combination was collected during each sampling period. Sites were selected based on several factors, such as (a) location upstream or downstream of WWTF discharges, (b) the amount of algal growth that typically occurs in different river reaches, (c) the relative size of tributary inputs, and (d) safety considerations. Sites from RM 5.5 to 9.9 typically are influenced by large populations of algae during summer, and sites downstream of RM 38.1 are affected by discharges from major WWTFs (at RMs 38.1 and 9.3), whereas sites upstream are less affected by algal growth and WWTF discharges. Tributary sites with major contributions to the river were selected rather than sites in smaller tributaries. Finally, sites had to be safely accessible - sites that were wadeable or accessible by canoe were preferred for collecting bed sediment. In all, 92 samples were collected from July 1999 to June 2000 (fig. 2, table 1).

Potential sources to the decomposable material in bed sediment also were sampled. These included various types of organic material such as leaf litter, woody material, and organic detritus. Soil samples and effluent from the two major WWTFs were collected. A sample of bryozoans (filter-feeding aquatic invertebrates) also was collected. Materials were selected that were readily found in the basin and were either known to enter the stream network or could be expected to do so. In all, 50 samples of potential source materials were collected.

Bed Sediment.-The method used to collect bed sediment varied depending on the site and sampling period. For the preliminary study (late-summer-1998), a 4.2-cm diameter rigid plastic tube was used by scuba divers to obtain nine bed sediment cores from each of two sites. Core sampling was not feasible for the expanded study because some sites were accessible only by bridge. In addition, the stratigraphic information provided by cores was not needed, so a simpler method was used beginning with the mid-summer-1999 sampling period. At wadeable sites, bed sediment was collected using a stainless steel ladle to skim the top 1-2 cm of sediment from depositional areas. Areas close to the bank were avoided to reduce the contribution from nearby soil. Samples from at least three different depositional areas were obtained from each site and composited into an 8-oz glass jar. 


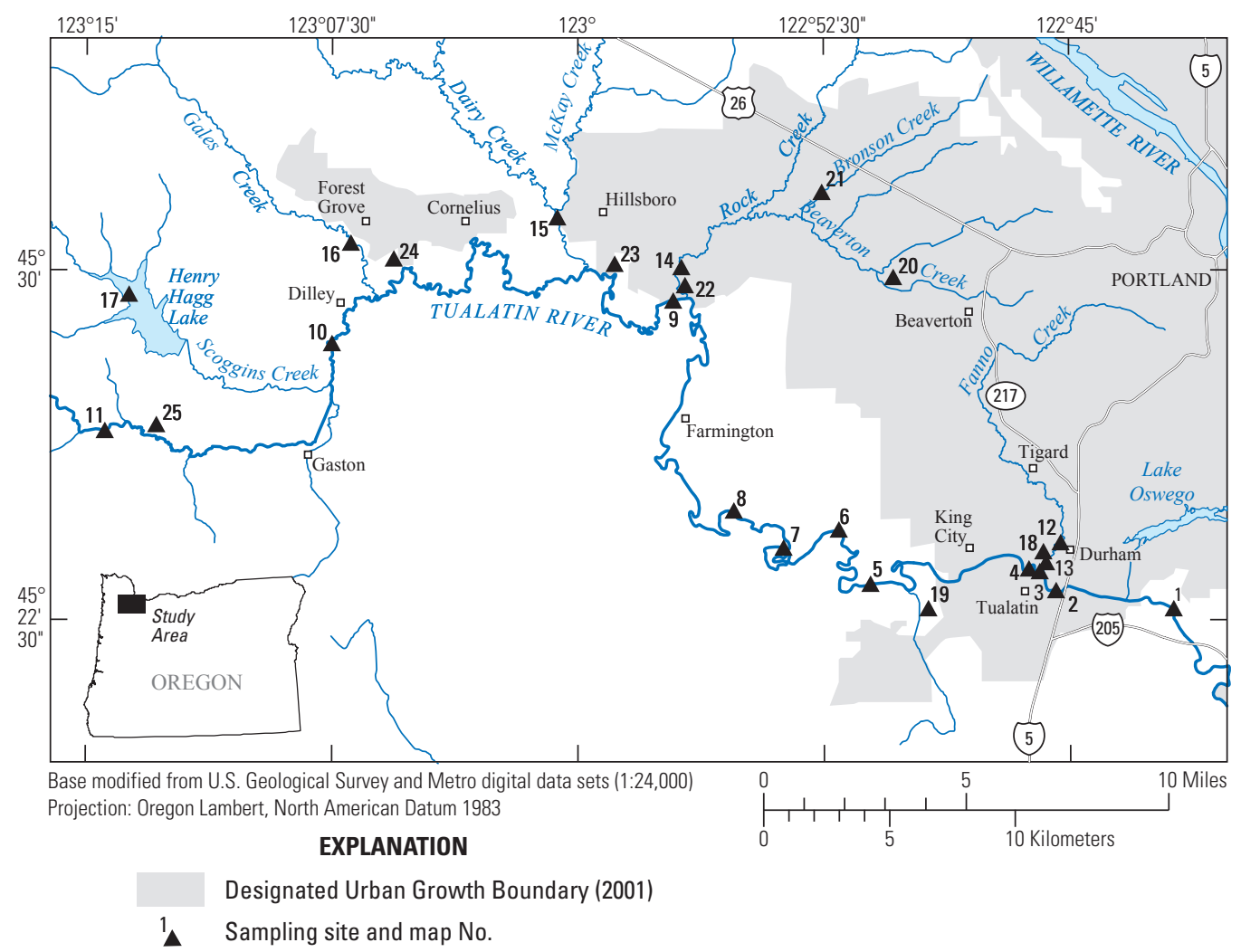

Figure 2. Location of sampling sites in the Tualatin River basin, Oregon.

At sites accessed by canoe or bridge, the same general method was applied to a grab sample of streambed sediment collected with an Ekman dredge. Obtaining an intact streambed sample of a depositional area was difficult at some sites. Chunks of wood, concrete, asphalt, and other debris frequently caught in the jaws of the Ekman dredge and caused any fine depositional material to be washed away as the apparatus was retrieved. Some samples consisted of only compacted clay with no depositional material. For these reasons, material from only two depositional areas was composited at the most difficult sites. Bed sediment sampling in the winter proved especially difficult because high flows caused the Ekman dredge to drift and become snagged on submerged debris, jeopardizing its retrieval. Consequently, bed sediment sampling for the winter period was discontinued after only two sites were sampled.

Suspended Sediment.--Suspended sediment was collected using a USGS suspended sediment sampler and the equal-width-increment method (Edwards and Glysson, 1999). A DH-59 sampler attached to a cable was used for deep sites; a
DH-81 hand sampler was used for shallow sites. A total of $4 \mathrm{~L}$ of water were collected at each site and stored in polyethylene bottles.

Seston.-A nylon plankton tow net with an 80 - $\mu$ m filter mesh was used to collect seston samples. The net was slowly towed (by canoe or by hand) in the upper $1 \mathrm{~m}$ of the water column but below the water surface. The concentrates from each tow were composited into glass jars until approximately $1 \mathrm{~L}$ of concentrate was collected. Total towing time ranged from as little as 5 minutes to more than 90 minutes, depending on the amount of seston in the river or lake.

Other Samples.-The method used to collect other samples depended on the sample type. In general, aggregated samples (soil, duckweed mat, leaf litter) were scooped with a stainless steel ladle, whereas discrete samples (twigs, leaves or needles, periphyton) were hand picked. All samples were placed in glass containers. Samples of wastewater effluent (50 L in stainless steel milk cans) were collected by the operators of the WWTFs. 
Table 1. Summary of sample collection at each sampling site, Tualatin River basin, Oregon.

[Location of map No. is shown in figure 2. Gray shading indicates collection of sample. BS, bed sediment; SS, suspended sediment; Ses, seston. Access: C, canoe; B, Bridge; W, wading; T, terrestrial; O, other. RM, river mile]

\begin{tabular}{|c|c|c|c|c|c|c|c|c|c|c|c|c|c|c|c|c|c|c|}
\hline \multirow{2}{*}{$\begin{array}{l}\text { Map } \\
\text { No. }\end{array}$} & \multirow[t]{2}{*}{ Site name } & \multirow{2}{*}{ Access } & \multicolumn{3}{|c|}{$\begin{array}{c}\text { Late-summer } \\
1998\end{array}$} & \multicolumn{3}{|c|}{$\begin{array}{l}\text { Mid-summer } \\
1999\end{array}$} & \multicolumn{3}{|c|}{$\begin{array}{c}\text { Late-summer } \\
1999\end{array}$} & \multicolumn{3}{|c|}{$\begin{array}{c}\text { Winter } \\
2000\end{array}$} & \multicolumn{3}{|c|}{$\begin{array}{c}\text { Early-summer } \\
2000\end{array}$} & \multirow[t]{2}{*}{ Other } \\
\hline & & & BS & SS & Ses & BS & SS & Ses & BS & SS & Ses & BS & SS & Ses & BS & SS & Ses & \\
\hline 1 & Tualatin River at RM 5.5 (Stafford Road) & C, B & & & & & & & & & & & & & & & & \\
\hline 2 & Tualatin River at RM 8.7 (Boones Ferry Bridge) & C & & & & & & & & & & & & & & & & \\
\hline 3 & Tualatin River at RM 9.4 (Basalt sill) & C & & & & & & & & & & & & & & & & \\
\hline 6 & Tualatin River at RM 20.3 & C & & & & & & & & & & & & & & & & \\
\hline 7 & Tualatin River at RM 24.5 & $\mathrm{~T}$ & & & & & & & & & & & & & & & & \\
\hline 8 & Tualatin River at RM 26.9 (Scholls) & $C, B$ & & & & & & & & & & & & & & & & \\
\hline 9 & Tualatin River at RM 38.4 (Rood Bridge) & $C, B$ & & & & & & & & & & & & & & & & \\
\hline 10 & Tualatin River at RM 58.8 (Dilley) & W, B & & & & & & & & & & & & & & & & \\
\hline 14 & Rock Creek at Highway 8 & W, B & & & & & & & & & & & & & & & & \\
\hline 15 & Dairy Creek at Highway 8 & W, B & & & & & & & & & & & & & & & & \\
\hline 16 & Gales Creek at old Highway 47 & W, B & & & & & & & & & & & & & & & & \\
\hline 17 & Henry Hagg Lake & C & & & & & & & & & & & & & & & & \\
\hline \multicolumn{19}{|c|}{ Other sites } \\
\hline 18 & Durham Wastewater Treatment Facility & 0 & & & & & & & & & & & & & & & & \\
\hline 19 & Onion Flat (Cipole Road and Highway 99W) & $\mathrm{T}$ & & & & & & & & & & & & & & & & \\
\hline 20 & Tualatin Nature Park & $\mathrm{T}$ & & & & & & & & & & & & & & & & \\
\hline 21 & Oregon Graduate Institute (near Bronson Creek) & $\mathrm{T}$ & & & & & & & & & & & & & & & & \\
\hline 22 & Rock Creek Wastewater Treatment Facility & 0 & & & & & & & & & & & & & & & & \\
\hline 23 & Jackson Bottom (between Miller Swale and holding pond) & $\mathrm{T}$ & & & & & & & & & & & & & & & & \\
\hline
\end{tabular}

\section{Sample Processing}

After collection, samples were stored at $4{ }^{\circ} \mathrm{C}$ until processing, which generally occurred within 48 hours. Sample processing differed somewhat for bulk materials (including bed sediment, leaf litter, and soil) versus filterable material (seston, suspended sediment, and WWTF effluent).

Bulk Material.-Bulk material first was examined visually for extraneous material, which was removed with forceps; for example, wood pieces were removed from bed sediment samples. Some bulk material was hand sorted into fractions, such as cones and twigs, which were separated from duckweed mat. Next, the sample was frozen and then freeze-dried. The resulting dehydrated material was ground in a mill and portioned into three glass vials (called "sample splits") that were sent for isotopic analysis.

Filtered Material.- - Suspended sediment and solids from WWTF effluent were captured on $0.45-\mu \mathrm{m}$ glass fiber filters that had been baked at $500{ }^{\circ} \mathrm{C}$ for 4 hours. The WWTF effluent was centrifuged before filtering to concentrate the solids. One-half of the seston sample was filtered though a $202-\mu \mathrm{m}$ nylon filter to remove zooplankton and any macroscopic debris. The resulting seston filtrate contained phytoplankton as well as suspended material in the $80-202 \mu \mathrm{m}$ size range. Ten $\mathrm{mL}$ of this fraction was removed, preserved with formalin, and sent for algal speciation analysis. Solids from the seston filtrate and the remaining unfiltered fraction were captured separately on $0.45-\mu \mathrm{m}$ glass fiber filters. All sample filters were frozen and then freeze-dried. Each dried filter was cut into three approximately equal wedges that were divided among three glass vials (sample splits) and sent for isotopic analysis.

Summer 1998.-Sample processing differed for the preliminary study. Bed-sediment cores were frozen and then sectioned according to depth. The top 1,2, or $3 \mathrm{~cm}$ of a core was used depending on the core. Bed sediment was not composited; rather, each core-section sample was treated separately. Core sections and other bulk materials were dried 
at 45 or $57^{\circ} \mathrm{C}$, then ground in a mill and divided into vials. Bulk materials (other than core sections) were split into three glass vials (sample splits). Samples requiring filtration were treated the same as just described for samples collected after 1998 , except that the filters were dried at 45 or $57^{\circ} \mathrm{C}$. Filters were cut into three sections which were divided among vials (sample splits).

\section{Analytical Methods}

\section{Stable Isotope and Elemental Analysis}

Sample splits were analyzed for carbon and nitrogen isotopic and elemental composition by Dr. Carol Kendall's laboratory at the USGS facility in Menlo Park, California. Their method will be summarized here; for a detailed description, see Kendall and others (2001). Bulk sample splits were subsampled as received. Sample splits on filters were scraped into a dish and then ground before subsampling. Approximately $2 \mathrm{mg}$ subsamples were used for highly organic samples (seston and plant material) and 18-25 mg subsamples were used for samples that contained less organic matter (bed and suspended sediment and WWTF effluent). Following their standard protocols, the subsamples were vapor acidified to remove carbonate and then analyzed using a Carlo Erba ${ }^{\circledR}$ elemental analyzer attached to a Micromass Optima mass spectrometer.

Carbon and nitrogen isotopic compositions generally are expressed as a $\delta$ value in units of per mil (parts per thousand). A $\delta$ value is calculated relative to standards, carbon in PeeDee belemnite (PDB) and nitrogen in air (see equation 1). A substance with a higher $\delta$ value contains relatively more of the heavier isotope $\left({ }^{13} \mathrm{C}\right.$ or $\left.{ }^{15} \mathrm{~N}\right)$ and relatively less of the lighter isotope $\left({ }^{12} \mathrm{C}\right.$ or $\left.{ }^{14} \mathrm{~N}\right)$ than a substance with a lower $\delta$ value. The changes in percent composition are very small-a 1 per mil change corresponds to a 0.0011 and 0.0004 percent change in isotope composition for $\delta^{13} \mathrm{C}$ and $\delta^{15} \mathrm{~N}$, respectively.

Carbon and nitrogen content was measured for all samples. For samples collected on filters, however, an unknown amount of glass fiber was included when the filter was scraped, thus making the percent carbon and percent nitrogen values individually meaningless. The $\mathrm{C} / \mathrm{N}$ ratio, however, is valid and that is the value reported here as an atomic ratio.
Quality Assurance.-Dr. Kendall's laboratory routinely analyzes approximately 10 percent of samples in duplicate and analyzes additional splits if results are not within their expected reproducibility. About 15 percent of the analyses for this study were laboratory splits ("lab splits"). As described, all Tualatin River basin samples (except the 1998 core sections) were submitted to the laboratory as triplicate sample splits. The variance of lab splits was not significantly different from the variance of sample splits $(\alpha=0.05$, F-test). If the sample material had not been homogeneous before being divided into triplicate splits, the pooled variance of the sample splits would have exceeded that of the lab splits. The fact that the variances are not different is an indication that all splits (sample and lab) were equivalent. Therefore, lab split and sample split results were treated identically.

Some of the Tualatin River basin sample results, especially for bed sediment and suspended sediment samples, had poorer than expected reproducibility for $\delta^{15} \mathrm{~N}$. Laboratory results indicated that these samples typically contained little nitrogen, less than 1 micromole $(14 \mu \mathrm{g})$. Nitrogen content was low enough in some cases that it was near the detection limit of the analytical instrument, causing the measurement to have only one significant digit. This resulted in higher variability among $\mathrm{C} / \mathrm{N}$ ratios for the sample.

After the first sets of samples from the Tualatin River basin had been analyzed, it was evident that acidification was affecting $\delta^{15} \mathrm{~N}$, but not $\delta^{13} \mathrm{C}$, which was exactly the opposite of the desired effect. Samples typically are acidified to prevent carbonate from affecting the $\delta^{13} \mathrm{C}$ of the organic carbon in the sample, and the acidification should not alter the $\delta^{15} \mathrm{~N}$. Evidently, samples from the Tualatin River basin contained little carbonate and particularly labile nitrogen (C. Kendall, written commun., February 25, 1999). For a number of subsequent samples, both acidified and unacidified subsamples were analyzed. These results confirmed the previous observations. Only unacidified subsamples were analyzed for the last sampling period (early-summer-2000). The inconsistency in acidification procedures resulted in data that were not necessarily comparable. For about 50 percent of the samples, all subsamples were acidified before analyses. For about 30 percent of the samples, no subsamples were acidified. The remaining samples had some, but not all subsamples, acidified before analysis. Making these data compatible with each other required devising a method to remove the artifact associated with acidification; this method is described later in this report (see section, "Acidification Correction").

$$
\delta^{13} \mathrm{C}=\left[\frac{\left(\frac{{ }^{13} \mathrm{C}}{{ }^{12} \mathrm{C}}\right)_{\text {sample }}}{\left(\frac{{ }^{13} \mathrm{C}}{{ }^{12} \mathrm{C}}\right)_{P D B}}-1\right] \times 1000 \quad \delta^{15} \mathrm{~N}=\left[\frac{\left(\frac{{ }^{15} \mathrm{~N}}{{ }^{14} \mathrm{~N}}\right)_{\text {sample }}}{\left(\frac{{ }^{15} \mathrm{~N}}{{ }^{14} \mathrm{~N}}\right)_{\text {Air }}}-1\right] \times 1000
$$




\section{Other Analyses}

Algal speciation and enumeration was performed by Aquatic Analysts (Friday Harbor, Washington) on formalin-preserved samples by microscopic examination and counting at least 500 colonies. Chlorophyll- $a$ concentrations in river water were measured by the Clean Water Services Water-Quality Laboratory (Hillsboro, Oregon) as part of a routine monitoring program. Samples were collected weekly; interpolation was used for dates that did not coincide with a routine sampling date. Clean Water Services participates in a quality assurance program for chlorophyll- $a$ analysis with the USGS Oregon Water Science Center.

\section{Statistical Methods}

Several statistical methods were used in this study. Parametric methods (ordinary least squares, linear regression, mean, standard deviation, and Student's $t$-test) were used to evaluate results of sample splits, which can be expected to be normally distributed. For comparisons among sample results, non-parametric methods were used, including analysis of variance on ranked data, Mann-Whitney U test, and Spearman rank-order regression (Miller and Miller, 1988; SAS Institute Inc., 1989; Helsel and Hirsch, 1992). A criterion of $\alpha=0.05$ was used for statistical significance unless otherwise noted. Principal components analysis was performed on normalized data (SAS Institute Inc., 1989).

\section{Data Aggregation and Manipulation}

Triplicate sample splits were submitted for almost all samples, with the intent to calculate a mean value and confidence limits for each sample. Two inconsistencies related to changes in methods of sample collection and analytical procedures resulted in data that were not necessarily compatible among splits and could complicate comparisons among samples. Specifically,

- In the 1998 preliminary study, core sections of bed sediment were submitted separately; after 1998, bed sediment samples were submitted as triplicate sample splits of homogenized composites of surficial sediment.

- Acidification of samples prior to analysis was not consistent and appeared to affect results for nitrogen.

The following protocol was devised to produce a final dataset that was as internally consistent as possible.

1. If a split (sample or lab) was acidified, the $\delta^{15} \mathrm{~N}$ and $\mathrm{C} / \mathrm{N}$ results were "corrected" using a linear relation described in section, "Acidification Correction." This correction should make all $\delta^{15} \mathrm{~N}$ and $\mathrm{C} / \mathrm{N}$ results comparable and equivalent to "unacidified." No correction was needed for $\delta^{13} \mathrm{C}$.
2. With the exception of the 1998 bed sediment samples, the mean and standard deviation were calculated from the combined results of sample splits and lab splits for each sample. This approach is valid because the sample split variance and lab split variance were not significantly different.

3. For 1998 bed sediment samples, lab splits were done for some core-section samples but not for others. Sample splits were not done for these samples, and it cannot be assumed that one core section was the same as another core section. Consequently, a weighted technique was used to calculate the mean and standard deviation, giving the same total weight to each core-section sample.

4. The standard deviation was adjusted for $\delta^{15} \mathrm{~N}$ and $\mathrm{C} / \mathrm{N}$ averages that were calculated from only acidified results. In this case, the variability associated with the acidifiedunacidified correction equation was incorporated. Details of this adjustment are discussed in section, "Standard Deviation Adjustment."

\section{Acidification Correction}

Laboratory personnel judged that acidified splits produced the most reliable results for $\delta^{13} \mathrm{C}$ and percent carbon, and that unacidified splits were better for $\delta^{15} \mathrm{~N}$ and percent nitrogen. Because acidified and unacidified splits were not analyzed for every sample, it was necessary to devise a correction factor for acidification. Data from the 32 samples having both acidified and unacidified results were examined. The mean value was used when multiple lab or sample splits had been analyzed, otherwise discrete values were used. Analysis of acidified versus unacidified data regressions (fig. 3 ) showed that the $\delta^{13} \mathrm{C}$ regression line was not significantly different from the $\mathrm{y}=\mathrm{x}$ line, but the $\delta^{15} \mathrm{~N}$ and $\mathrm{C} / \mathrm{N}$ regressions were significantly different from the $y=x$ line $(\alpha=0.05)$. These results confirmed previous observations: acidification did not significantly affect $\delta^{13} \mathrm{C}$, but systematically decreased $\delta^{15} \mathrm{~N}$. Acidification increased $\mathrm{C} / \mathrm{N}$ slightly, which is consistent with the hypothesis that some of the nitrogen was labile.

Data shown in figure 3 represent samples of bed sediment, suspended sediment, seston, plant material, and WWTF effluent solids. When the effect of acidification on $\delta^{15} \mathrm{~N}$ was first observed, it was thought to be limited to the sediment samples. Treating sediment samples separately from the others, however, showed similar regression statistics between acidified and unacidified results; therefore, all types of samples were included.

Regression equations were applied to all acidified results for $\delta^{15} \mathrm{~N}$ and $\mathrm{C} / \mathrm{N}$, correcting them to the equivalent of unacidified results (table 2). No correction was applied to $\delta^{13} \mathrm{C}$ results because the regression line was not significantly different from $\mathrm{y}=\mathrm{x}$. 


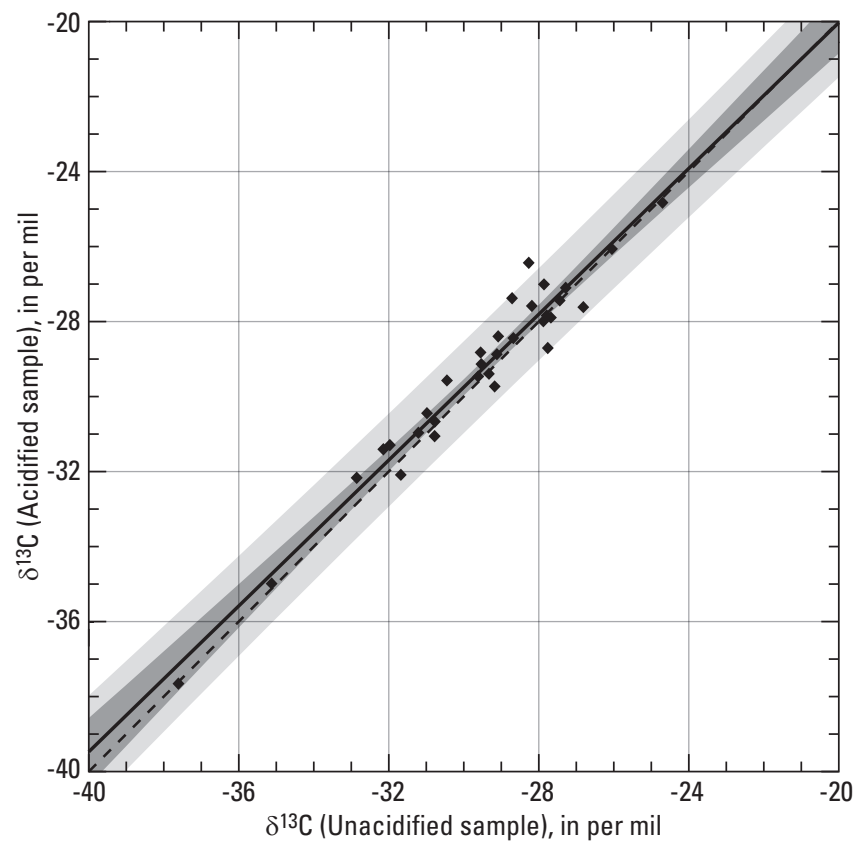

\section{EXPLANATION}

Regression line

$95 \%$ confidence limit of regression line

$95 \%$ prediction limit of regression

- - - y=x line (1-to-1 line)
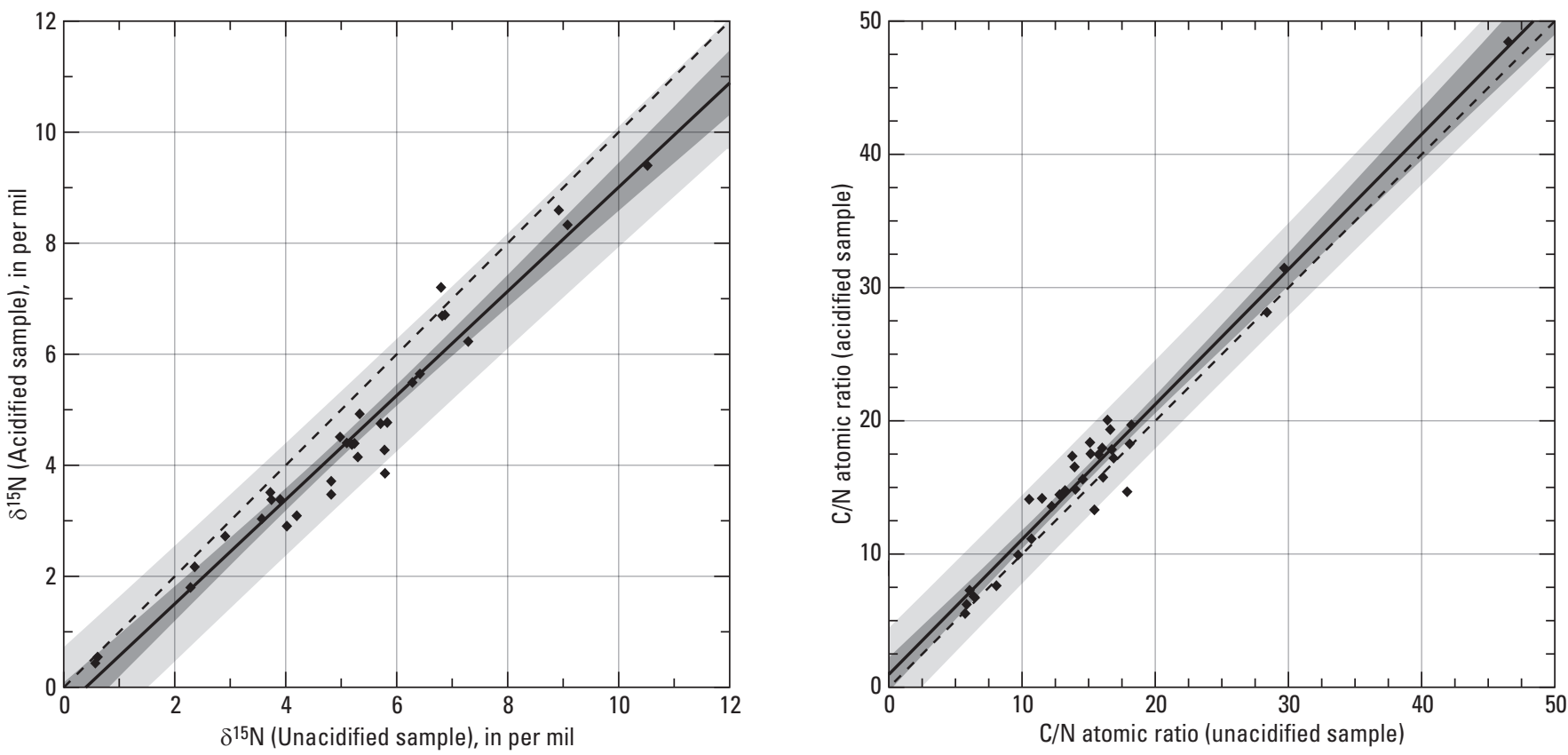

Figure 3. Regression results for acidified versus unacidified samples from the Tualatin River basin, Oregon. Regression for $\delta^{13} \mathrm{C}$ is not significantly different from the $\mathrm{y}=\mathrm{x}$ line. Regressions for $\delta^{15} \mathrm{~N}$ and the $\mathrm{C} / \mathrm{N}$ atomic ratio are significantly different from the $y=x$ line $(\alpha=0.05)$. 
Table 2. Relation between acidified and unacidified $\delta^{13} \mathrm{C}, \delta^{15} \mathrm{~N}$, and $\mathrm{C} / \mathrm{N}$ results for samples from the Tualatin River basin, 0 regon.

[Abbreviations: $\mathrm{r}^{2}$, square of the Pearson correlation coefficient; $\mathrm{N}$, number of points in regression]

\begin{tabular}{|c|c|c|c|c|c|}
\hline \multirow[b]{2}{*}{ Parameter } & \multicolumn{3}{|c|}{ Regression statistics } & \multirow{2}{*}{$\begin{array}{c}\text { Significantly } \\
\text { different from } y=x ? \\
(\alpha=0.05)\end{array}$} & \multirow[b]{2}{*}{ Correction equation } \\
\hline & $\mathbf{r}^{2}$ & $\begin{array}{c}\text { Standard } \\
\text { error }\end{array}$ & $\mathbf{N}$ & & \\
\hline$\delta^{13} \mathrm{C}$ & 0.95 & 0.588 & 32 & No & None \\
\hline$\delta^{15} \mathrm{~N}$ & 0.95 & 0.487 & 32 & Yes & Unacidified $=($ Acidified +0.3675$) / 0.9385$ \\
\hline $\mathrm{C} / \mathrm{N}$ & 0.96 & 1.360 & 32 & Yes & Unacidified $=($ Acidified -0.8405$) / 1.0131$ \\
\hline
\end{tabular}

\section{Standard Deviation Adjustment}

As previously described, the mean and standard deviation of all splits was calculated for each sample (a weighted method was used for bed-sediment core sections) after $\delta^{15} \mathrm{~N}$ and $\mathrm{C} / \mathrm{N}$ values were corrected for the effects of acidification. For $\delta^{15} \mathrm{~N}$ and $\mathrm{C} / \mathrm{N}$ results in the case where all splits were acidified, the calculated standard deviation underestimates the potential variability because it does not include the variability associated with the acidification correction regression. To remedy this situation, additional variance was added to the variance for the acidified samples:

$$
\operatorname{var}\left(x_{o}\right)=\frac{s_{e}^{2}}{\operatorname{slope}^{2}}\left(\frac{1}{n}+\frac{n\left(y_{o}-\bar{y}\right)^{2}}{\operatorname{slope}^{2} S_{x x}}\right),
$$

where

$$
\begin{aligned}
& s_{e}^{2}=\frac{S_{x x} S_{y y}-\left(S_{x y}\right)^{2}}{n(n-2) S_{x x}} \\
& S_{x x}=n \sum_{i=1}^{n}\left(x_{i}-\bar{x}\right)^{2} \text { and } S_{y y}=n \sum_{i=1}^{n}\left(y_{i}-\bar{y}\right)^{2} \text { and } S_{x y}=n \sum_{i=1}^{n}\left(x_{i}-\bar{x}\right)\left(y_{i}-\bar{y}\right)
\end{aligned}
$$

$n$ is the number of points in the regression line, and

$x, y$ points are unacidified values and acidified values, respectively.

Confidence intervals of the sample means provide guidance for interpreting differences; these intervals were calculated using a two-tailed Student's $t$-test at the 95-percent level. The mean 95-percent confidence limits are shown in table 3.

\begin{tabular}{|c|c|c|c|}
\hline \multirow[b]{3}{*}{ All splits acidified } & \multicolumn{3}{|c|}{ Mean 95-percent confidence interval (number of samples) } \\
\hline & $\delta^{13} \mathrm{C}$ & $\delta^{15} \mathrm{~N}$ & $\mathrm{C} / \mathrm{N}$ atomic ratio \\
\hline & $\pm 0.32 \quad(55)$ & \pm 0.44 & \pm 1.7 \\
\hline All splits unacidified & \pm 0.33 & \pm 0.79 & \pm 2.3 \\
\hline Mixed acidification & \pm 0.53 & \pm 0.74 & \pm 1.2 \\
\hline
\end{tabular}

Table 3. Confidence intervals of sample means for samples from the Tualatin River basin, Oregon. 


\section{Characterization of Bed Sediment and Source Materials}

Isotopic results for $\delta^{13} \mathrm{C}$ and $\delta^{15} \mathrm{~N}$ as well as the $\mathrm{C} / \mathrm{N}$ ratios for each sample are shown in table 6 (at back of report). The full datasets are shown in appendix A.

\section{Bed Sediment}

$\delta^{13} \mathrm{C}$. - The $\delta^{13} \mathrm{C}$ of bed sediment for Tualatin River basin samples generally is between -29.4 and -26.9 per mil (fig. 4). No general trend with river mile was evident, although the lowest values of $\delta^{13} \mathrm{C}$ in the river tended to occur at RM 9.9. Among the tributaries, $\delta^{13} \mathrm{C}$ values for the Rock and Fanno Creek sites were lower than those for either the Gales or Dairy Creek sites. There were no statistically significant differences between tributary and river sites; however, the Rock and Fanno Creek results more closely resembled Tualatin River results from RM 8.7-9.9, whereas the Gales and Dairy Creek results were more similar to results from most upstream river sites.

The $\delta^{13} \mathrm{C}$ results for the late-summer-1999 samples were lower than those obtained at any other time. The lowest $\delta^{13} \mathrm{C}$ value measured for bed sediment, -30.6 per mil, was obtained during this sampling period. Median differences for pairwise site-matched comparisons between late-summer-1999 results and those from mid-summer-1999 and early-summer-2000 were -1.9 and -1.4 per mil, respectively, which were statistically different from zero $(\alpha=0.05$, fig. 5$)$. Statistical tests for differences with late-summer-1998 and with winter-2000 were not possible because the number of samples was too small.

Pairwise site-matched comparisons also showed that $\delta^{13} \mathrm{C}$ for mid-summer-1999 was greater than $\delta^{13} \mathrm{C}$ for early-summer-2000. Because the difference was consistent among all samples (river and tributaries), it was highly significant ( $\mathrm{p}<0.001)$, but it also was small $(0.7 \mathrm{per}$ mil). Although this difference may reflect a real seasonal effect (such as differences in source material), it is possible that this is a spurious correlation or an artifact related to laboratory performance that changed over time.

$\delta^{15} \mathrm{~N}$.-The $\delta^{15} \mathrm{~N}$ of bed sediment for Tualatin River basin samples generally is between 1.7 and 6.3 per mil (fig. 4). No trends related to season or sampling period were observed.

Inspection of the $\delta^{15} \mathrm{~N}$ results shows that the data divide neatly into two groups: Group A comprising lower river sites at and downstream of RM 26.9 plus the Rock Creek site, and Group B including river sites upstream of RM 26.9 plus the Gales, Dairy and Fanno Creek sites (fig. 4). The $\delta^{15} \mathrm{~N}$ of
Group A generally is between 4.9 and 6.3 per mil, whereas the $\delta^{15} \mathrm{~N}$ of Group B generally is between 1.7 and 4.9 per mil. The difference in $\delta^{15} \mathrm{~N}$ values between these groups is statistically significant. Two possibilities that could account for this difference are decomposition and WWTF effects. Increases in $\delta^{15} \mathrm{~N}$ values of several per mil have been observed to occur with progressive decomposition (Bernasconi and others, 1997; Kendall and others, 2001). If the degree of decomposition explains the difference between Groups A and B, it could indicate that the sediments in the tributary and upper river sites were "fresher" than materials found in the lower river. This explanation is consistent with observed differences in measured SOD rates, which were statistically higher at tributary sites than at Tualatin River sites (Rounds and Doyle, 1997). Alternatively, if the dissolved nitrogen discharged from the WWTFs tends to be heavier (higher $\delta^{15} \mathrm{~N}$ ), then it is possible that vegetation in the riparian corridor downstream of the Rock Creek WWTF (RM 38.1) also might have a heavier nitrogen content. Transport of leaf litter with a higher $\delta^{15} \mathrm{~N}$ from the near riparian area might help explain the higher $\delta^{15} \mathrm{~N}$ of the bed sediment samples collected at and downstream of RM 26.9. Neither of these hypotheses, however, can be tested with the available data.

The $\delta^{15} \mathrm{~N}$ results from late-summer-1998 bed sediment samples should be regarded with some skepticism. These samples were collected and processed using a different method than the other samples (cores versus surficial sediment grab samples, and drying at about $50{ }^{\circ} \mathrm{C}$ versus freeze drying). It is not known if these collection and processing differences affected the results, but it would not be unreasonable to suspect that the higher temperature drying method caused additional nitrogen fractionation. Laboratory personnel remarked that the nitrogen in Tualatin River bed sediment samples was particularly labile. Because of the processing difference, these samples were omitted from further analysis.

$\mathrm{C} / \mathrm{N}$ ratio. - The $\mathrm{C} / \mathrm{N}$ atomic ratio of bed sediment samples from the Tualatin River basin generally falls within a narrow range of 12.5-17.7 (fig. 4). No trends related to river mile or sampling period were observed with the exception of the two winter-2000 samples which had much higher C/N ratios. Both samples from winter-2000 contained woody debris and although the larger pieces were removed from the samples during processing, it is likely that some wood remained in the sample at the time of analysis. Because of this confounding variable and the general lack of winter samples, it is impossible to draw conclusions about $\mathrm{C} / \mathrm{N}$ ratios in bed sediment during the winter season. Two samples obtained in early-summer-2000 had particularly low $\mathrm{C} / \mathrm{N}$ ratios which cannot be attributed to any known cause. 


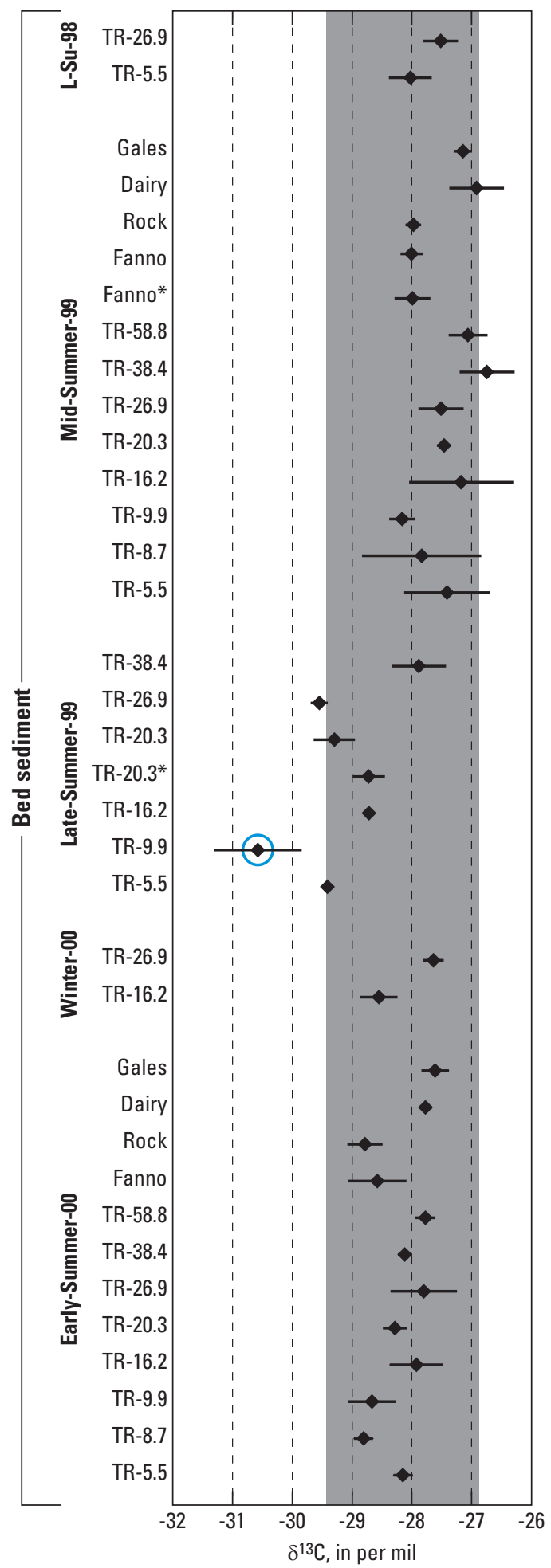

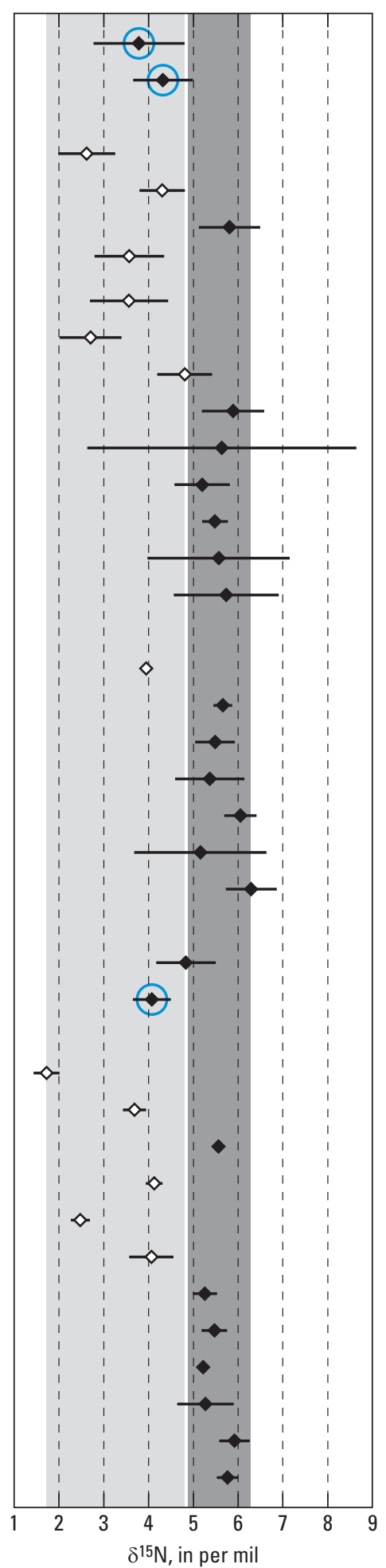

EXPLANATION

5th-95th percentile of means represented by filled dots

Minimum-maximum of means represented by open dots

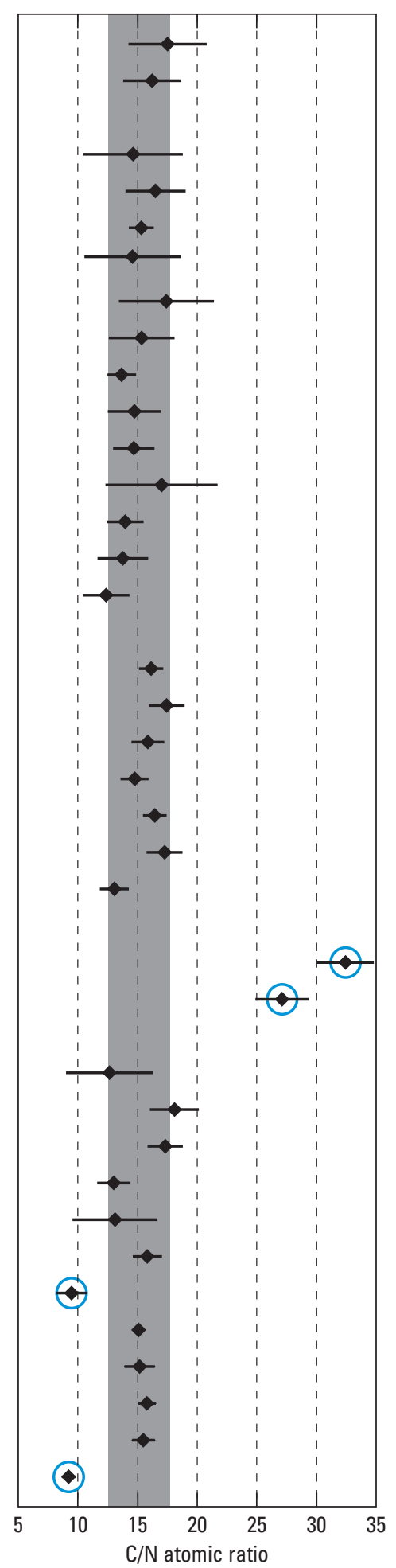

Outlier-outside 1.5x interquartile range Open and filled interval of meaninto two groups

Figure 4. Stable isotope results and $\mathrm{C} / \mathrm{N}$ ratios for bed sediment samples from the Tualatin River basin, showing observed ranges (shaded areas) and outliers (circled values). Lower river and Rock Creek $\delta^{15} \mathrm{~N}$ values (filled dots) are greater than those for upper river and tributary sites (open dots). [Abbreviations: L-Su=late summer, $T R=$ Tualatin River, number following $T R=$ river mile location, ${ }^{*}=$ sample that included deeper anoxic sediment in addition to surficial sediment]. 


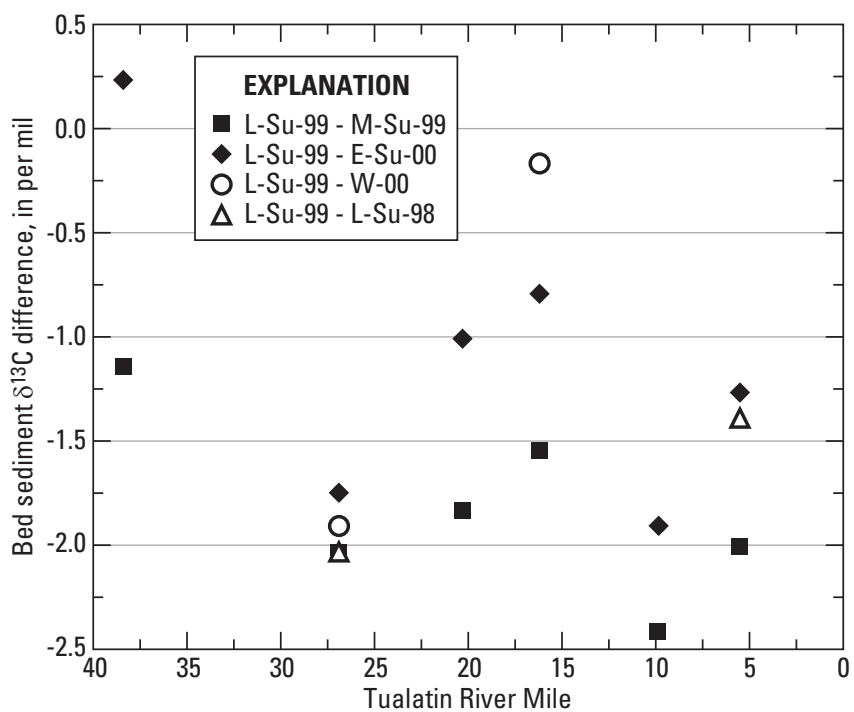

Figure 5. Pairwise $\delta^{13} \mathrm{C}$ differences for several sampling periods compared to results from latesummer-1999. [L-Su= late-summer, E-Su = early-summer, $\mathrm{M}-\mathrm{Su}=$ mid-summer, $\mathrm{W}=$ winter $]$.

\section{Leaf Litter and Soil}

Coniferous litter, deciduous litter, and woody litter show similar values of $\delta^{13} \mathrm{C}, \delta^{15} \mathrm{~N}$, and $\mathrm{C} / \mathrm{N}$ ratios (fig. 6). The only statistically significant difference among these sample data is that $\delta^{15} \mathrm{~N}$ is slightly higher for woody material than for coniferous litter. Different plants utilize different biochemical pathways during photosynthesis, and the pathway affects the isotopic composition. The ranges of $\delta^{13} \mathrm{C}, \delta^{15} \mathrm{~N}$, and $\mathrm{C} / \mathrm{N}$ values measured in this study are similar to those reported elsewhere for plants that use the $\mathrm{C} 3$ pathway of $\mathrm{CO}_{2}$ uptake (table 4). Vegetation in the riparian areas of the Tualatin Basin is almost exclusively trees and shrubs that utilize the C3 pathway, rather than plants that use the $\mathrm{C} 4$ pathway (corn, bamboo and tropical grasses) or the CAM pathway (cacti and desert plants).
The range for $\mathrm{C} / \mathrm{N}$ is wide, with the highest values associated with cones, seed pods and woody material. Wide ranges of $\mathrm{C} / \mathrm{N}$ are not uncommon for terrestrial material in various stages of decay (Kendall and others, 2001).

As materials decompose, the carbon and nitrogen content both decrease. The rates of decay are such that the $\mathrm{C} / \mathrm{N}$ ratio generally decreases as the material becomes progressively more decomposed (Middelburg and Nieuwenhuize, 1998; Kendall and others, 2001). In addition, $\delta^{15} \mathrm{~N}$ tends to shift toward higher values as the lighter isotopes are removed during decomposition (Bernasconi and others, 1997; Middelburg and Nieuwenhuize, 1998; Kendall and others, 2001). Reported changes in $\delta^{13} \mathrm{C}$ with decomposition, however, show less agreement. Middelburg and Nieuwenhuize (1998) reported that the $\delta^{13} \mathrm{C}$ was 2-3 per mil lower for more degraded material, but Kendall and others (2001) reported that $\delta^{13} \mathrm{C}$ usually increased with decomposition, although the changes were small.

Two samples of decomposed terrestrial detritus were compared to plant litter in this study. Because only two samples of decomposed terrestrial detritus were collected and the same material was not tracked through the decomposition process, caution in interpretation is warranted. The $\delta^{13} \mathrm{C}$ values for detritus are within the range for plant litter, suggesting that $\delta^{13} \mathrm{C}$ changed little during decomposition for these samples. The detrital $\delta^{15} \mathrm{~N}$ values, however, are at the high end of the range for litter, suggesting that some fractionation of nitrogen might have occurred during decomposition. Furthermore, the $\mathrm{C} / \mathrm{N}$ ratios for the detritus samples are at the low end of the range for litter, supporting the hypothesis that the $\mathrm{C} / \mathrm{N}$ ratio decreases with increasing decomposition.

Soils collected in the Tualatin River basin resemble plant litter for $\delta^{13} \mathrm{C}$ and $\delta^{15} \mathrm{~N}$, but have lower $\mathrm{C} / \mathrm{N}$ values that are similar to those of the decomposed terrestrial detritus (fig. 6). This change in $\mathrm{C} / \mathrm{N}$ ratio is what would be expected as soil organic matter derived from plant material ages and becomes more decomposed.

Table 4. Ranges of $\delta^{13} \mathrm{C}$ and $\delta^{15} \mathrm{~N}$ values and $\mathrm{C} / \mathrm{N}$ ratios for terrestrial plant material.

\begin{tabular}{lccc}
\hline \multicolumn{1}{c}{ Source } & $\begin{array}{c}\delta^{\mathbf{1 3}} \mathbf{C} \\
\text { (per } \text { mil) }\end{array}$ & $\begin{array}{c}\delta^{\mathbf{1 5}} \mathbf{N} \\
\text { (per mil) }\end{array}$ & $\begin{array}{c}\text { C/N } \\
\text { (atomic ratio) }\end{array}$ \\
\hline This study & -30.4 to -21.1 & -3.0 to 5.4 & 20 to 111 \\
Typical reported range $^{1}$ & -32 to -22 & -10 to 10 & 15 to $>50$ \\
\hline
\end{tabular}

\footnotetext{
${ }^{1}$ Typical reported range for vascular plants (C3 pathway) from Finlay and Kendall (2007).
} 


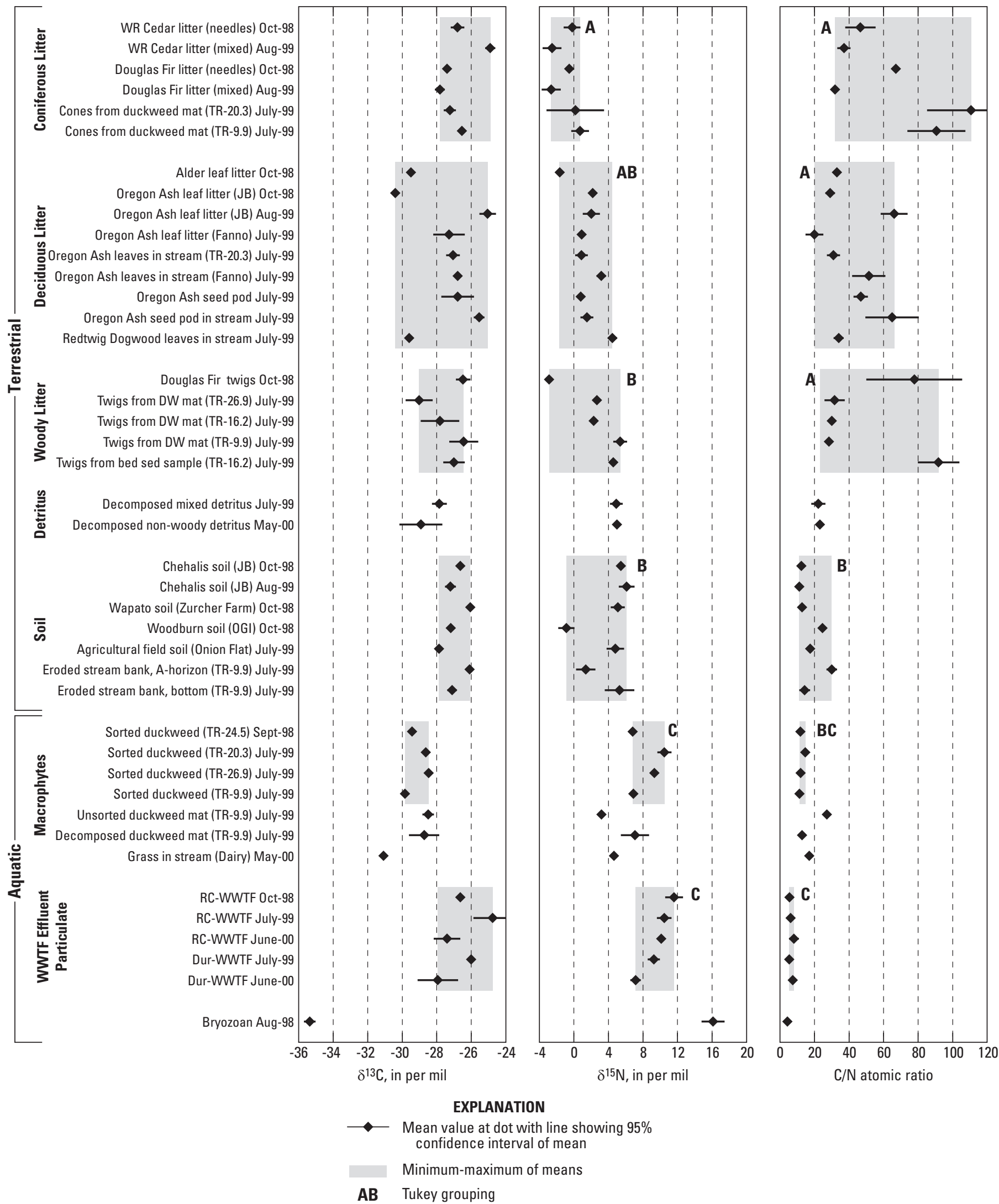

Figure 6. Stable isotope results for potential source materials of sedimentary organic matter with shading showing observed ranges for each type of material in the Tualatin River basin, Oregon. Groups with statistically significant differences $(\alpha=0.05)$ are denoted with different letters (Tukey Grouping). No significant differences were found among the groups for $\delta^{13} \mathrm{C}$. [Abbreviations: WR=Western Red, $T R=$ Tualatin River, number following TR = river mile location, JB = Jackson Bottom, DW = duckweed, $0 \mathrm{Gl}=$ Oregon Graduate Institute, $\mathrm{RC}=$ Rock Creek, Dur $=$ Durham, WWTF $=$ Wastewater Treatment Facility. 


\section{Macrophytes}

Duckweed is a common macrophyte in the Tualatin River. Duckweed mats on the order of $1 \mathrm{~m}^{2}$ or larger are not unusual during low flow in the summer, particularly where they collect on the upstream side of a stationary floating object such as a log. In addition to duckweed, these mats collect small cones and twigs. Compared to terrestrial plant litter, sorted duckweed (only duckweed leaves and roots) had slightly lower $\delta^{13} \mathrm{C}$ (-29.8 to -28.5 per mil), higher $\delta^{15} \mathrm{~N}$ (6.8 to 10.5 per mil), and lower $\mathrm{C} / \mathrm{N}$ (11.2 to 14.6) values (fig. 6); the differences for $\delta^{15} \mathrm{~N}$ and $\mathrm{C} / \mathrm{N}$ were statistically significant. The $\delta^{13} \mathrm{C}$ is less than typical values reported in the literature for aquatic macrophytes (-27 to -20 per mil; Finlay and Kendall, 2007). The $\mathrm{C} / \mathrm{N}$ range is particularly narrow for duckweed compared to terrestrial plant litter. Compared to sorted duckweed, the unsorted material had $\delta^{15} \mathrm{~N}$ and $\mathrm{C} / \mathrm{N}$ values closer to leaf litter, showing the influence of cones and twigs. The decomposed duckweed sample had values similar to the unsorted material.

Two large WWTFs discharge treated municipal effluent into the Tualatin River at RMs 38.1 and 9.3. The $\delta^{13} \mathrm{C}$ values for effluent particulate $(>0.45 \mu \mathrm{m})$ are similar to those for terrestrial plant litter and soils (fig. 6). The $\delta^{15} \mathrm{~N}$ values are significantly greater than those measured for the terrestrial plants or soils that were sampled. $\delta^{15} \mathrm{~N}$ results for sorted duckweed and WWTF effluent particulate samples are similar (7.2 to 11.6 per mil). This similarity may be a coincidence, but it is not unreasonable to conclude that duckweed downstream of RM 38.1 obtain a substantial amount of nitrogen from WWTF effluent. Bioavailable nitrogen is in abundant supply due to the WWTF discharges, and uptake in such circumstances typically does not alter the isotopic composition of the nitrogen source (Finlay and Kendall, 2007). Because only WWTF effluent particulate were analyzed in this study, it is not known if the $\delta^{15} \mathrm{~N}$ of dissolved nitrogen in effluent is similar. Compared to other sources, the $\mathrm{C} / \mathrm{N}$ values for effluent particulate are very low (5.3 to 8.0).

\section{Phytoplankton and Periphyton}

The reservoir reach (RM 30-3.4) of the Tualatin River is known for algal production. Because of the river depth and turbidity in this reach, little light reaches the river bottom except at the edges. As a result, most algae in this reach are phytoplankton (free-floating algae); however, periphyton (attached algae) are common at a few riffle sections. To sample phytoplankton, seston samples were collected during the summer from RMs 26.9 to 5.5. As previously described in the Sample Processing section, two size fractions were prepared. Figure 7 shows that the $\delta^{13} \mathrm{C}, \delta^{15} \mathrm{~N}$, and $\mathrm{C} / \mathrm{N}$ values for the two size fractions of seston ( $>80 \mu \mathrm{m}$ and $80-202 \mu \mathrm{m})$ are nearly identical, indicating that the presence of zooplankton or macroscopic debris in the $>80 \mu \mathrm{m}$ sample did not have a significant effect. Only results for the 80-202 $\mu \mathrm{m}$ size fraction are included in subsequent data analyses.
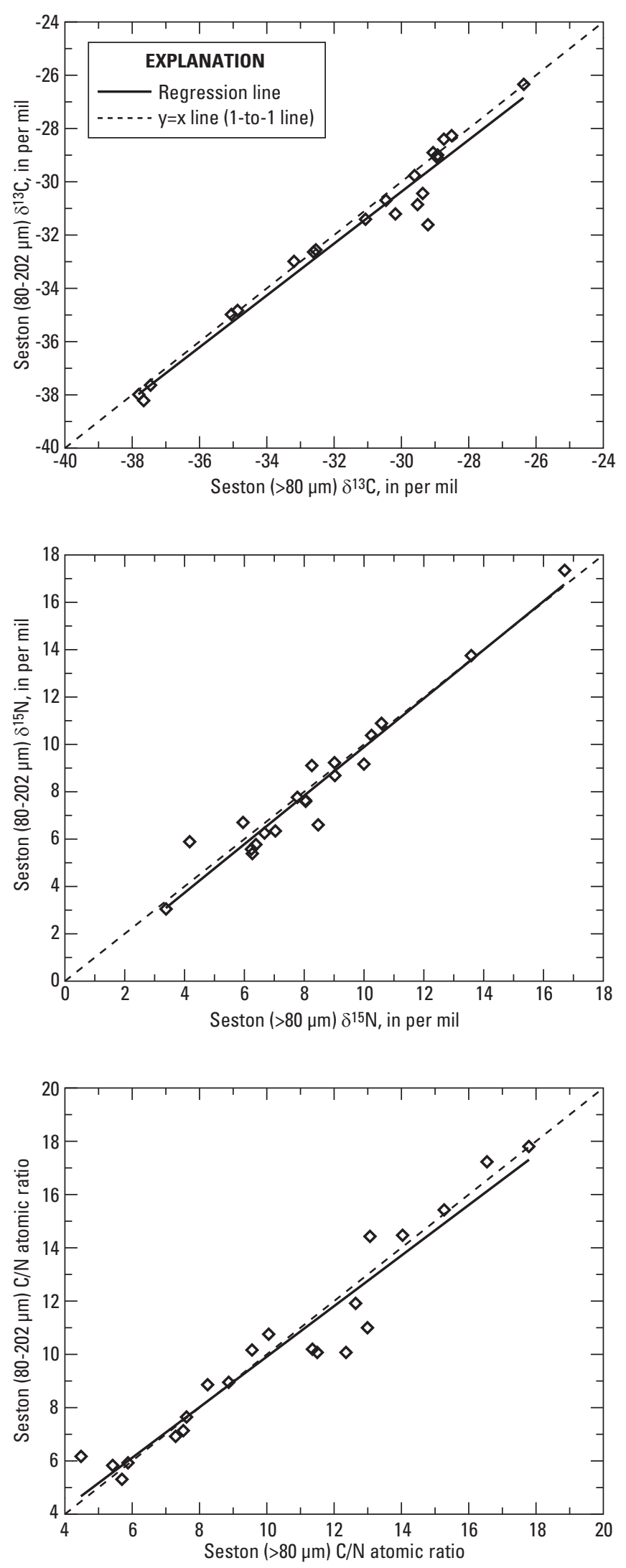

Figure 7. Comparison of $\delta^{13} \mathrm{C}, \delta^{15} \mathrm{~N}$ and $\mathrm{C} / \mathrm{N}$ results for two size fractions of seston $(80-202 \mu \mathrm{m}$ and $>80 \mu \mathrm{m})$ for samples from the Tualatin River basin, Oregon. 
Seston samples showed distinctive and statistically significant $(\alpha=0.05)$ trends with river mile for $\delta^{13} \mathrm{C}, \delta^{15} \mathrm{~N}$ and $\mathrm{C} / \mathrm{N}$ (ig. $)$. The $\delta^{13} \mathrm{C}$ decreased from an average of -28.8 per mil at RM 26.9 to an average of -38.0 per mil at RM 5.5. Similarly, C/N values decreased from 16.5 to 6.1 . The $\delta^{15} \mathrm{~N}$ showed a similarly strong, but opposite trend; the average
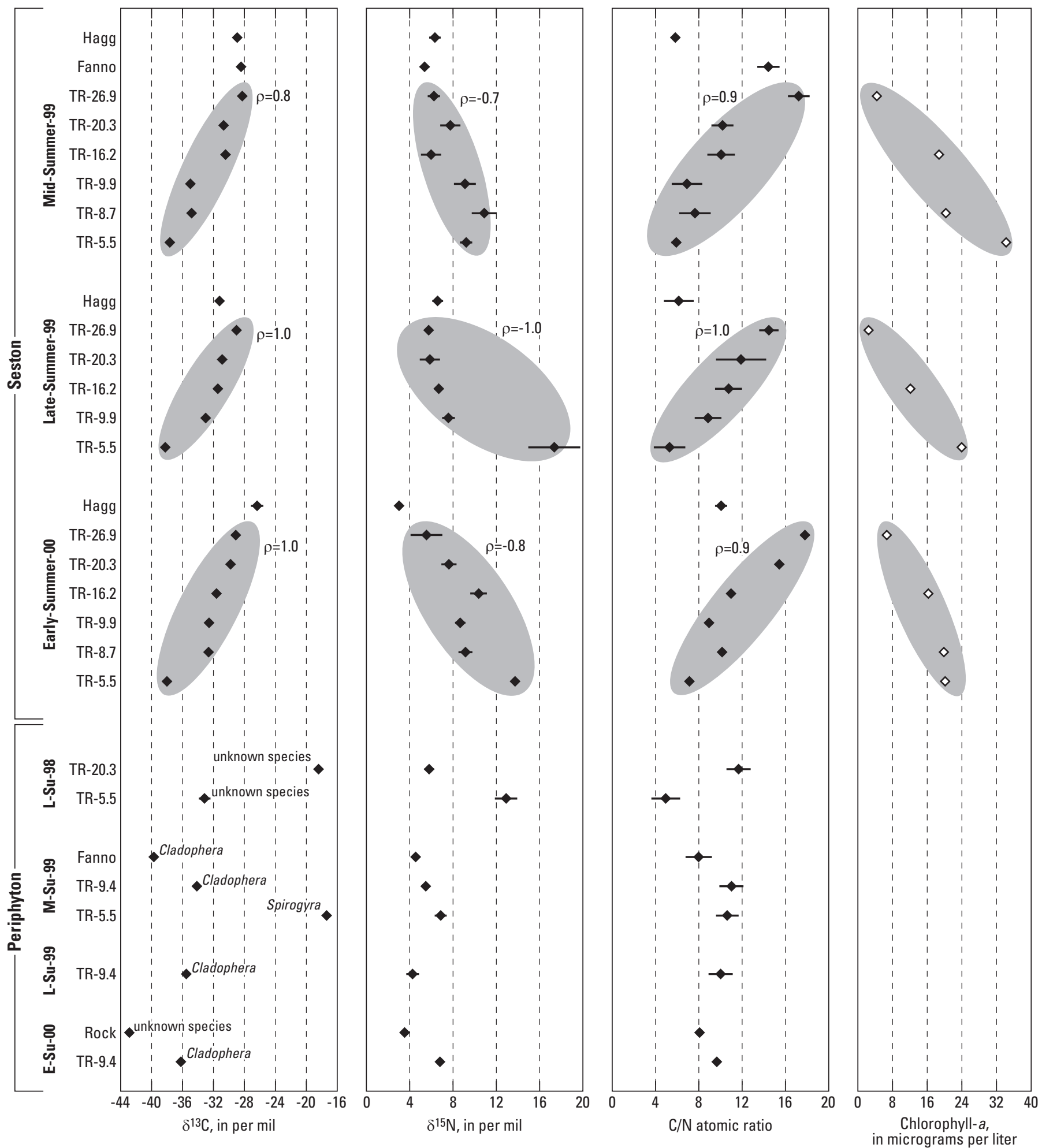

EXPLANATION

$\longrightarrow$ Mean value at dot with line showing 95\% confidence interval of mean

Data and Spearman coefficient $(\rho)$ for
$\rho=0.9 \quad$ correlation with river mile $(\alpha=0.05)$

$\diamond$ Measured or interpolated value

Figure 8. Stable isotope results for seston $(80-202 \mu \mathrm{m})$ and periphyton samples from the Tualatin River basin, Oregon, with shading
showing groups of Tualatin River samples. [TR=Tualatin River, number following TR = river mile location, L-Su =late-summer, $\mathrm{M}-\mathrm{Su}=$ mid-summer, $\mathrm{E}-\mathrm{Su}=$ early-summer]. 
$\delta^{15} \mathrm{~N}$ increased from 5.8 to 13.4 per mil. These changes reflect the increasing presence of phytoplankton in the lower (more downstream) reaches of the river as evidenced by increasing chlorophyll- $a$ concentrations. Samples that contain moderate to large amounts of phytoplankton ( $>15 \mu \mathrm{g} / \mathrm{L}$ chlorophyll- $a$ ), therefore, are characterized by low $\delta^{13} \mathrm{C}(<-32$ per mil), high $\delta^{15} \mathrm{~N}(>8$ per mil) and low $\mathrm{C} / \mathrm{N}(<12)$. These effects of location and chlorophyll- $a$ level are clearly evident when the $\delta^{15} \mathrm{~N}$ and $\mathrm{C} / \mathrm{N}$ are plotted against $\delta^{13} \mathrm{C}$ in figure 9 with annotations showing the chlorophyll- $a$ concentrations.

Hagg Lake seston showed a pattern that was different from seston in the Tualatin River (fig. 8). Visual examination of all Hagg Lake seston samples showed appreciable amounts of phytoplankton. The $\mathrm{C} / \mathrm{N}$ ratios of these samples are similar to the samples from the lower river that contain the most phytoplankton, but the $\delta^{13} \mathrm{C}$ and $\delta^{15} \mathrm{~N}$ values indicated much less fractionation. The low concentrations of nutrients in Hagg Lake compared to the lower Tualatin River may account for the differences between the seston samples from these locations. Algae have been reported to exhibit less isotopic fractionation when carbon and nitrogen are in short supply relative to the algal growth rate (Finlay and Kendall, 2007).

Periphyton samples from this study show a wide range of $\delta^{13} \mathrm{C}, \delta^{15} \mathrm{~N}$, and $\mathrm{C} / \mathrm{N}$ values (fig. 8). Although $\delta^{13} \mathrm{C}$ values for most periphyton samples are similar to those for phytoplankton-rich seston (<-32 per mil), two samples (one-quarter of the total) had anomalously high $\delta^{13} \mathrm{C}$ values (near -18 per mil). No other samples collected during this study had $\delta^{13} \mathrm{C}$ values that high. The $\delta^{15} \mathrm{~N}$ values for periphyton generally were less than those for seston samples with high levels of chlorophyll- $a(<8$ per mil compared to $>8$ per mil); the $\mathrm{C} / \mathrm{N}$ values for phytoplankton-rich seston and periphyton were similar $(<12)$.

\section{Suspended Sediment}

Suspended sediment samples show trends with river mile that resemble those of seston samples, but the trends are not as robust: $\delta^{13} \mathrm{C}$ and $\mathrm{C} / \mathrm{N}$ decrease with increasing river mile and $\delta^{15} \mathrm{~N}$ increases (fig. 10). Suspended sediment samples with low $\delta^{13} \mathrm{C}\left(<-32\right.$ per mil), high $\delta^{15} \mathrm{~N}(>7$ per mil $)$ and low $\mathrm{C} / \mathrm{N}(<10)$ were from the same sections of the river where phytoplankton were most prevalent. This result is not surprising because the suspended sediment sampling did not attempt to exclude phytoplankton. As a result, the filterable material from the lower river reaches includes a substantial amount of plankton during the summertime growing period. The main difference between the suspended sediment and seston samples is that the former includes particles both smaller than $80 \mu \mathrm{m}$ and larger than $202 \mu \mathrm{m}$. The particles smaller than $80 \mu \mathrm{m}$ are composed of plankton as well as colloidal materials from soil and streambank materials. Particles larger than $202 \mu \mathrm{m}$ include some zooplankton as well as larger sediment and detrital materials. The more robust trend in the seston samples, therefore, is consistent with the fact that the seston samples are composed predominantly of plankton whereas the suspended
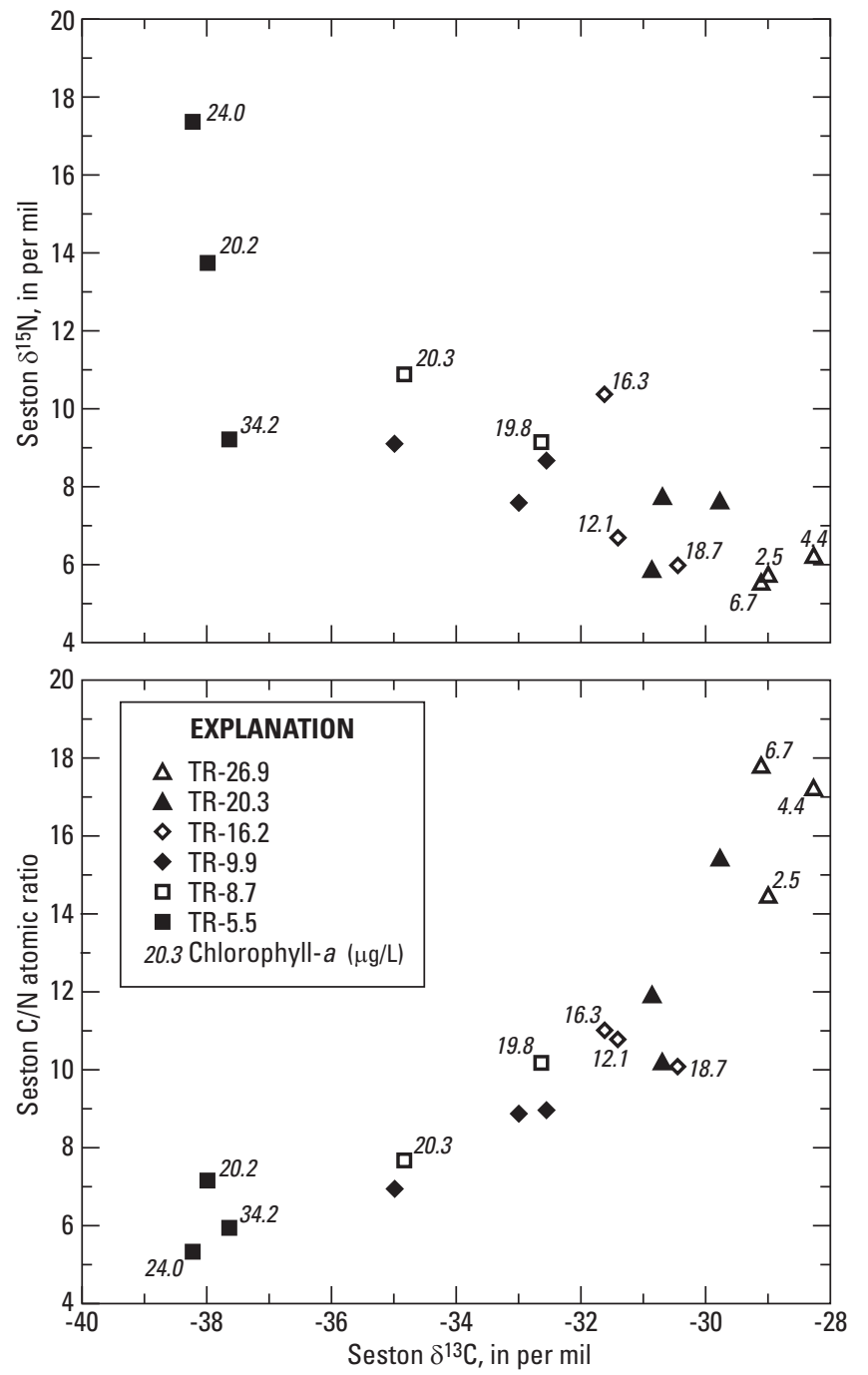

Figure 9. Relations between $\delta^{13} \mathrm{C}, \delta^{15} \mathrm{~N}$, and $\mathrm{C} / \mathrm{N}$ in seston samples from the Tualatin River, Oregon, show that high chlorophyll-a concentrations are associated with low $\delta^{13} \mathrm{C}$, high $\delta^{15} \mathrm{~N}$, and low $\mathrm{C} / \mathrm{N}$. [TR = Tualatin River, number following $\mathrm{TR}=$ river mile location].

sediment samples are a mixture of biological and other materials.

The decreasing trend in $\delta^{13} \mathrm{C}$ with river mile persists somewhat for the suspended sediment samples collected in winter, despite the fact that phytoplankton are not prevalent at that time of year due to high flow, limited light, and cold temperatures. The general lack of phytoplankton in winter is consistent with the absence of any trends with river mile for $\delta^{15} \mathrm{~N}$ and $\mathrm{C} / \mathrm{N}$ during the winter sampling. Consequently, the trend in $\delta^{13} \mathrm{C}$ during the winter is not directly attributable to downstream trends associated with plankton populations.

The $\delta^{15} \mathrm{~N}$ and $\delta^{13} \mathrm{C}$ results show that the suspended sediment samples can be separated into two groups: samples collected from the Tualatin River at and downstream of RM 26.9 have lower $\delta^{13} \mathrm{C}$ and higher $\delta^{15} \mathrm{~N}$ than samples collected from the upper river and tributaries $(\alpha=0.05)$. The primary difference, as discussed above, may be caused by the presence of more phytoplankton in the lower river samples. 

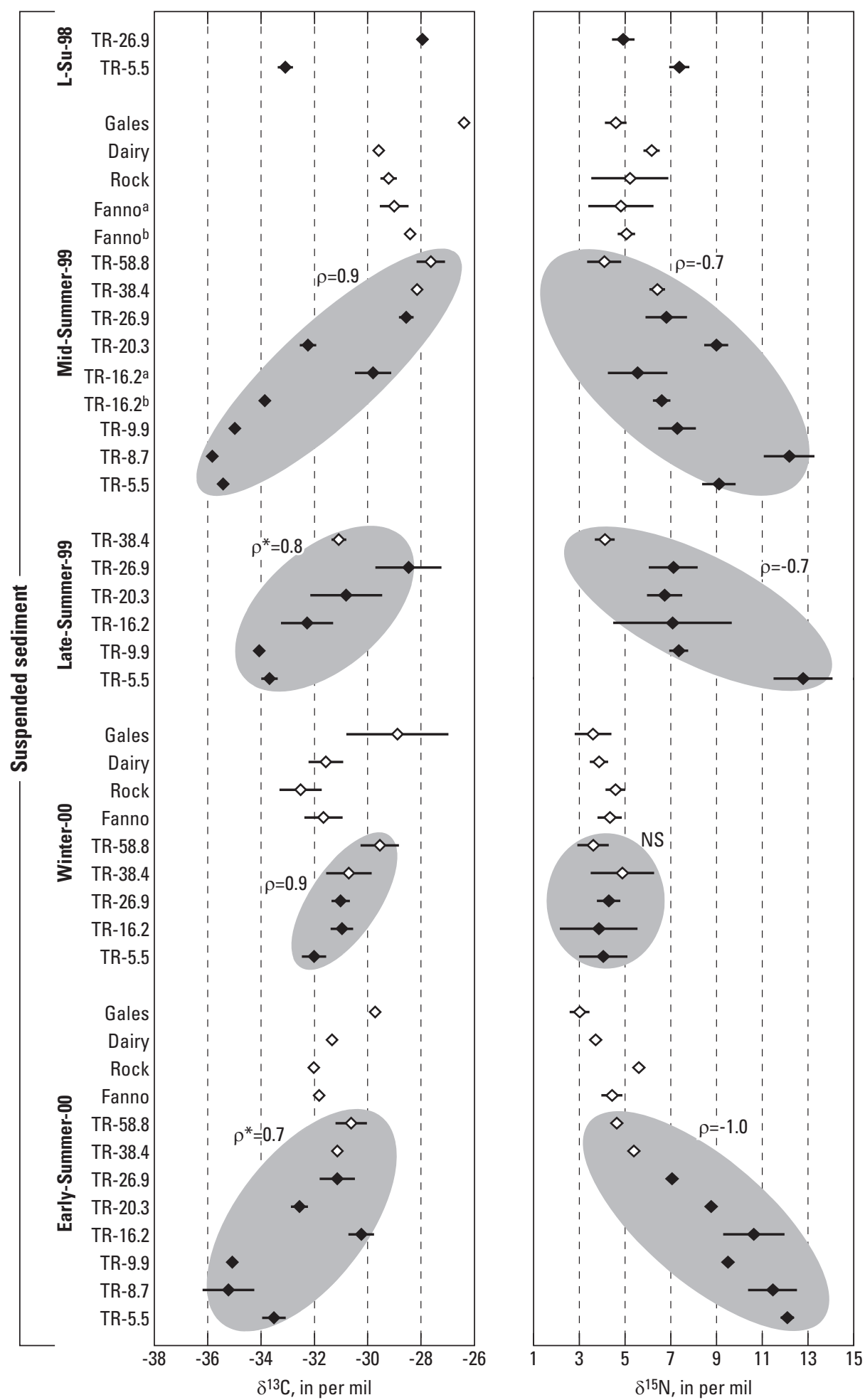

EXPLANATION

Mean value at dot with line showing $95 \%$ confidence interval of mean

$\longrightarrow$ Filled dots represent river sites downstream of RM 30

Open dots represent tributary sites plus river sites upstream of RM 30

Figure 10. Stable isotope results for suspended sediment samples from the Tualatin River basin, Oregon, with shading showing groups of Tualatin River samples. Trends with river mile shown with a correlation coefficient (Spearman $\rho$ ) were statistically significant ( $\alpha=0.05, \alpha=0.08$ for $\rho^{*}$, NS = not significant). [ ${ }^{a}=$ fraction that settled after 24 hours, ${ }^{b}=$ fraction remaining suspended after 24 hours, TR=Tualatin River, number following TR=river mile location, L-Su=late-summer]. 


\section{Potential Sources of Organic Matter to Tualatin River Sediments}

To assess the degree to which a range of sampled materials (soil, leaf litter, detritus, plankton, duckweed, WWTF effluent) might be important sources of organic material to Tualatin River bed sediment, the carbon and nitrogen isotopic data and $\mathrm{C} / \mathrm{N}$ ratios of these sources were compared to those of bed sediment. Because the organic material in bed sediment has decomposed over time, the isotopic and $\mathrm{C} / \mathrm{N}$ values have likely changed relative to their original sources. Microbial decomposition increases the $\delta^{15} \mathrm{~N}$ by a few per mil and can substantially decrease the $\mathrm{C} / \mathrm{N}$ ratio (Middelburg and Nieuwenhuize, 1998; Kendall and others, 2001). Finlay and Kendall (2007) report that the $\delta^{15} \mathrm{~N}$ increases associated with decomposition are most pronounced in streams that contain ample nitrate, a condition that is true for the Tualatin River. Decomposition also may alter the $\delta^{13} \mathrm{C}$, but the effect is less and tends to be small (Kendall and others, 2001).

Several substances (bryozoan, duckweed, periphyton, and WWTF effluent particulate) can be dismissed as primary sources of organic matter to bed sediment because the patterns in their isotopic and $\mathrm{C} / \mathrm{N}$ ratios do not match those of bed sediment, even if trends associated with decomposition are taken into account (fig. 11). The $\delta^{13} \mathrm{C}$ values for bryozoan and periphyton are substantially different from those of bed sediment. The $\delta^{15} \mathrm{~N}$ values of bryozoan, duckweed, and WWTF effluent particulate are greater than those for bed sediment. The $\mathrm{C} / \mathrm{N}$ values for bryozoan, periphyton and WWTF effluent particulate are less than those for bed sediment. As these substances decompose, their $\delta^{15} \mathrm{~N}$ values can be expected to increase and their $\mathrm{C} / \mathrm{N}$ ratios to decrease, making the differences compared to bed sediment even greater.

A comparison of seston and suspended sediment to bed sediment shows that the seston and suspended sediment samples that contain the most phytoplankton (those at and downstream of RM 16.2) do not resemble bed sediment for $\delta^{13} \mathrm{C}, \delta^{15} \mathrm{~N}$ or $\mathrm{C} / \mathrm{N}$ (fig. 12). The expected changes associated with decomposition (increased $\delta^{15} \mathrm{~N}$, decreased $\mathrm{C} / \mathrm{N}$ ) will further amplify these differences. Seston and suspended sediment obtained from tributaries and in the more upstream reaches of the Tualatin River compare more favorably with bed sediment. It is difficult to know whether this suspended particulate organic material is a source to the bed sediment or vice versa. Bed sediment samples collected in late-summer-1999 have lower $\delta^{13} \mathrm{C}$ and higher $\delta^{15} \mathrm{~N}$ than other bed sediment samples, which might indicate some contribution from phytoplankton. If the contribution of phytoplankton
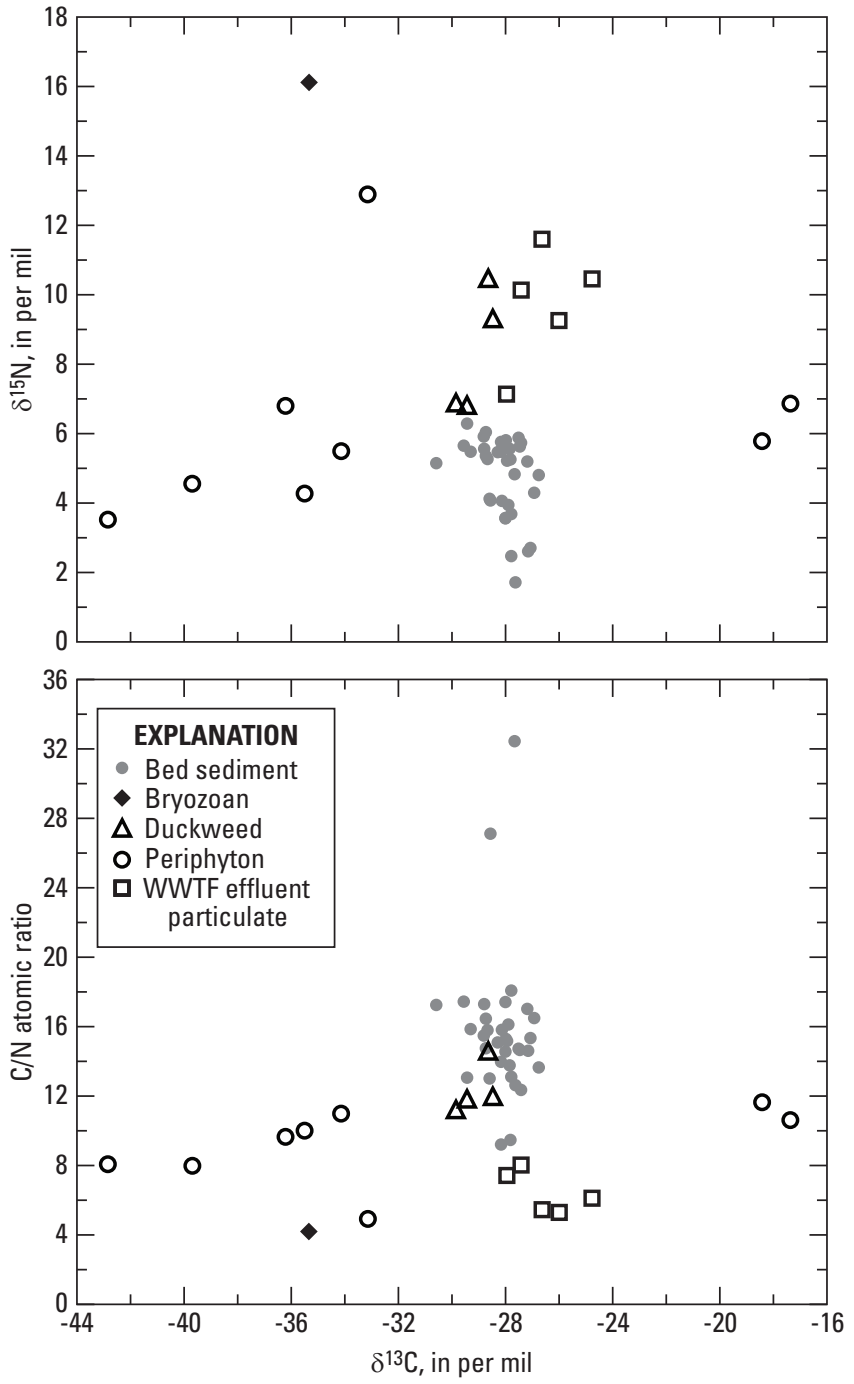

Figure 11. $\quad \delta^{13} \mathrm{C}, \delta^{15} \mathrm{~N}$ and $\mathrm{C} / \mathrm{N}$ values for bed sediment and several types of potential source materials from the Tualatin River basin, Oregon. [WWTF=Wastewater Treatment Facility].

to these samples were significant, however, the $\mathrm{C} / \mathrm{N}$ ratio of the late-summer-1999 bed sediment samples should have been lower. For all of these reasons, phytoplankton probably is not contributing significant amounts of organic matter to Tualatin River bed sediment. This conclusion is consistent with field measurements of SOD rates in the Tualatin River, which indicated that the river reaches with the largest algal populations did not have significantly higher SOD rates, except at RM 5.5 where a slightly higher rate might be attributed to some deposition of algal detritus (Rounds and Doyle, 1997). 
A comparison of terrestrial source materials to bed sediment shows considerable overlap for $\delta^{13} \mathrm{C}$ and $\delta^{15} \mathrm{~N}$ for deciduous litter, woody material, and soil (fig. 13). The range of $\delta^{13} \mathrm{C}$ values for plant litter and woody material encompasses the $\delta^{13} \mathrm{C}$ range for bed sediment. Although $\delta^{15} \mathrm{~N}$ values for many of the deciduous litter samples are lower than those of bed sediment, increasing these values by $2-3$ per mil (within the expected effect of decomposition) places them directly in the range of $\delta^{15} \mathrm{~N}$ values for bed sediment. The $\mathrm{C} / \mathrm{N}$ ratios for all litter and woody material samples are much higher
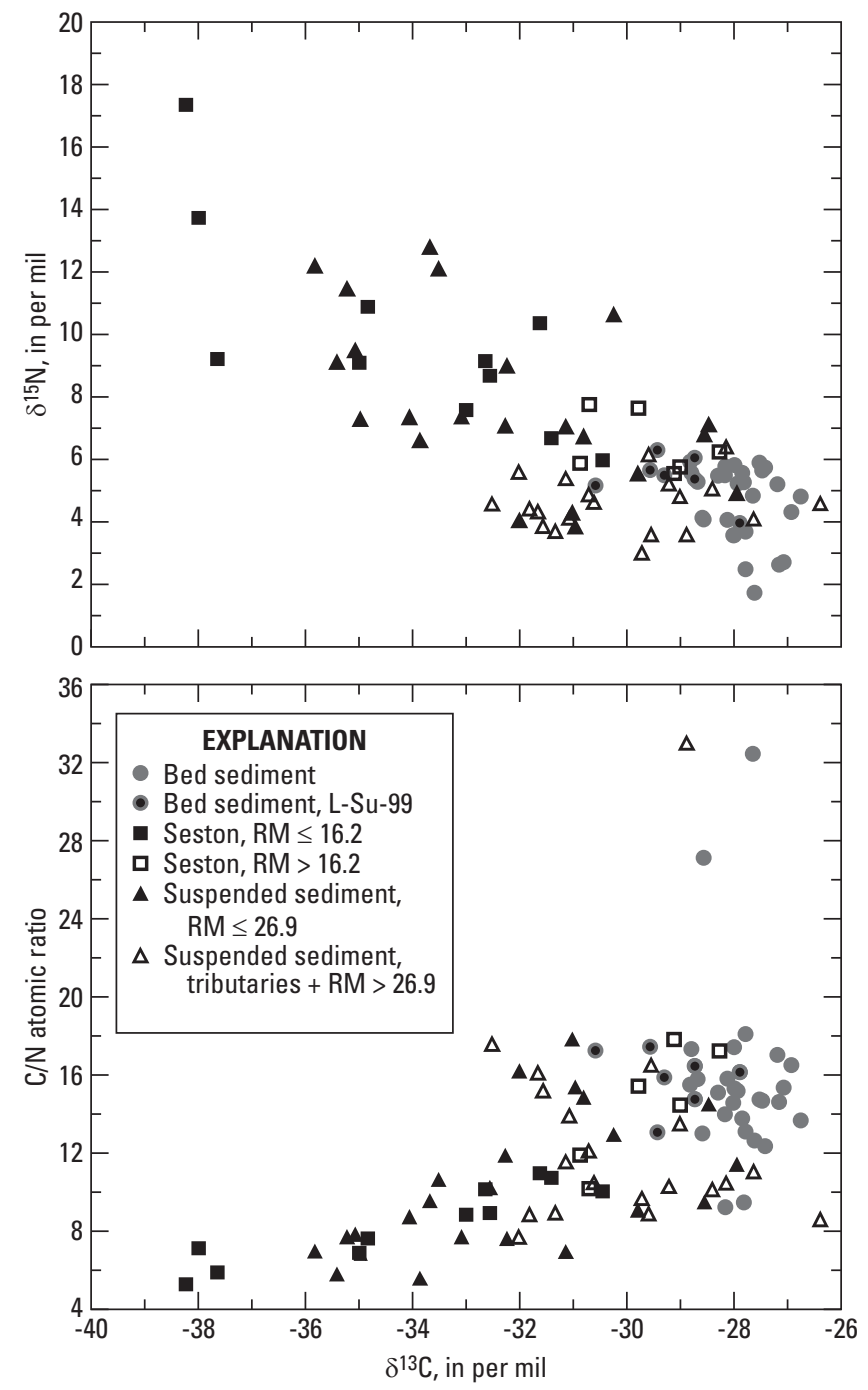

Figure 12. Comparison of $\delta^{13} \mathrm{C}, \delta^{15} \mathrm{~N}$ and $\mathrm{C} / \mathrm{N}$ for samples of bed sediment, suspended sediment, and seston from the Tualatin River basin, Oregon. [RM = river mile]. than those for bed sediment, but these ratios are expected to decrease with decomposition. In fact, the two samples of decomposed terrestrial detritus show $\mathrm{C} / \mathrm{N}$ ratios that are much more similar to those of bed sediment. The $\delta^{13} \mathrm{C}, \delta^{15} \mathrm{~N}$, and $\mathrm{C} / \mathrm{N}$ data from soil samples also show substantial overlap with the bed sediment data. Although this could indicate that eroded soil is a source of bed sediment, it is equally consistent with plant litter and woody material being the primary source of organic matter to soil and Tualatin River bed sediment.
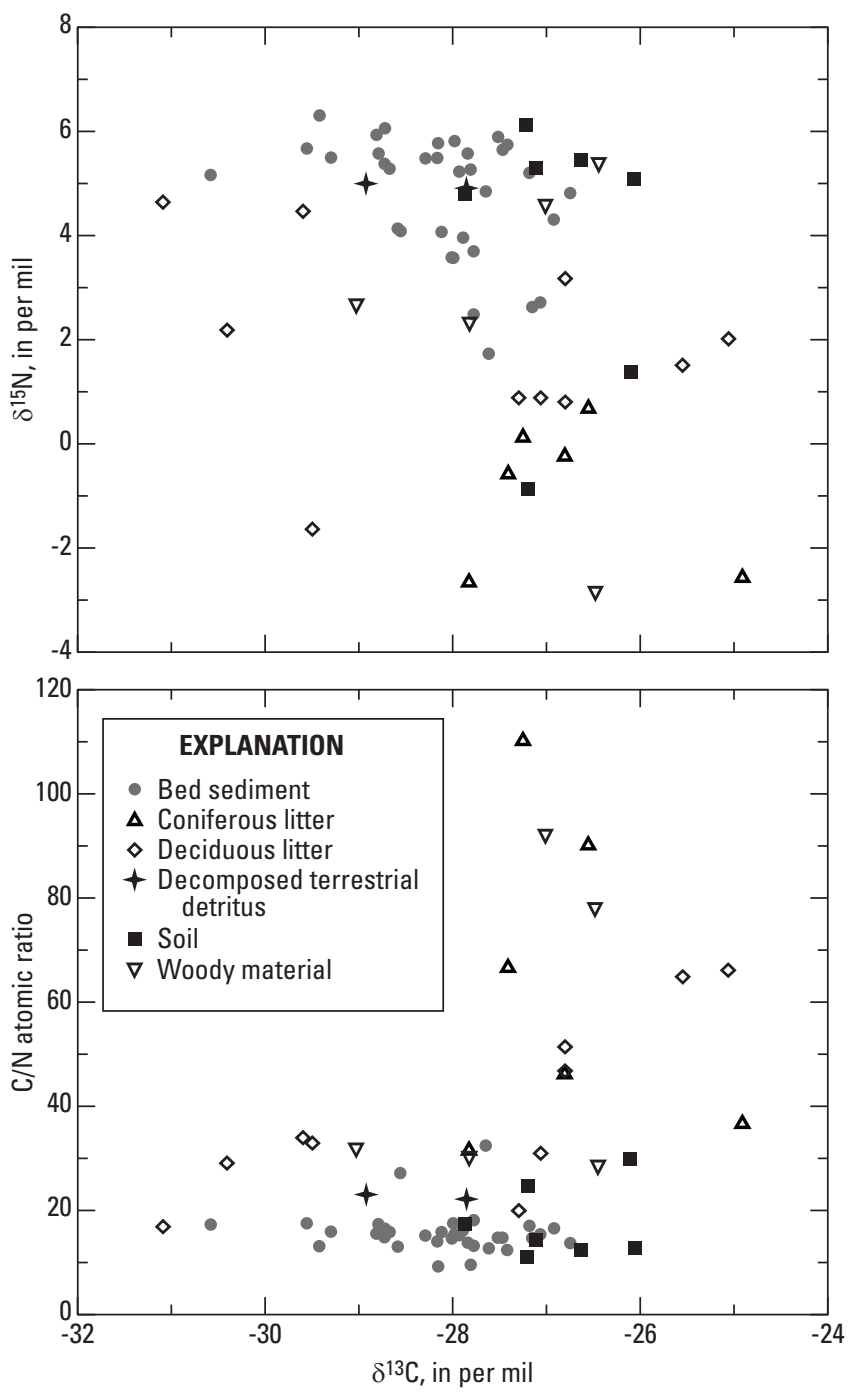

Figure 13. $\delta^{13} \mathrm{C}, \delta^{15} \mathrm{~N}$ and $\mathrm{C} / \mathrm{N}$ values of terrestrial materials and bed sediment samples from the Tualatin River basin, Oregon. 


\section{Principal Components Analysis}

Principal components analysis (PCA) is a statistical technique used to reduced the dimensionality of datasets that contain multiple variables. In PCA, new axes (principal components) are created that are linear combinations of the original variables. The greatest variability within the dataset is captured by the first principal component (PC1). The second principal component $(\mathrm{PC} 2)$ is orthogonal to $\mathrm{PC} 1$ and captures the greatest remaining variability. PCA was applied to this dataset as a method to visualize the three variables $\delta^{13} \mathrm{C}, \delta^{15} \mathrm{~N}$, and $\mathrm{C} / \mathrm{N}$ in a two dimensional plot. As part of PCA, the data were normalized (by subtracting the mean and dividing by the standard deviation of the dataset) to account for the different scales of the three variables $\left(\delta^{13} \mathrm{C}, \delta^{15} \mathrm{~N}\right.$, and $\left.\mathrm{C} / \mathrm{N}\right)$.

The results of the PCA are summarized in table 5. Together, $\mathrm{PC} 1$ and $\mathrm{PC} 2$ capture 86 percent of the variability in the dataset. The principal components plot is shown in figure 14. The black vectors (arrows) in that figure originate at the mean value for the entire dataset and point in the direction associated with each of the individual variables, $\delta^{13} \mathrm{C}$, $\delta^{15} \mathrm{~N}$, and $\mathrm{C} / \mathrm{N}$. Note that the $\delta^{13} \mathrm{C}$ vector is pointing toward increasing negative values (decreasing $\delta^{13} \mathrm{C}$ ) because that direction is most pertinent to this discussion.

Examination of the principal components graph (fig. 14) leads to the following observations, several of which were noted earlier:

- Bryozoan, duckweed, and WWTF effluent particulate do not plot at locations similar to bed sediments and, therefore, probably are not major sources of organic matter to bed sediment.

- Several soil samples plot in locations similar to those of bed sediment, suggesting that soil may contribute organic material to bed sediment or that the organic material in soil and bed sediments have a common source.
- Terrestrial litter (coniferous, deciduous, or woody) have principal component values characterized by higher $\mathrm{C} / \mathrm{N}$ and lower $\delta^{15} \mathrm{~N}$ compared to bed sediment. Decomposition of this material results in decreased $\mathrm{C} / \mathrm{N}$ and increased $\delta^{15} \mathrm{~N}$. Assuming a 25 percent decrease in $\mathrm{C} / \mathrm{N}$ coupled with a 2 per mil increase in $\delta^{15} \mathrm{~N}$ results in a trajectory that leads directly to the region where bed sediments plot. Examination of data reported by Middelburg and Nieuwenhuize (1998) for suspended matter in progressive stages of decomposition showed an approximate 10 percent decrease in $\mathrm{C} / \mathrm{N}$ with each 1 per mil increase in $\delta^{15} \mathrm{~N}$, which is consistent with the calculated trajectory from this study.

- Decomposition generally leads to increasing $\delta^{15} \mathrm{~N}$ and decreasing $\mathrm{C} / \mathrm{N}$. Although the slope is unknown, the typical direction is toward the upper left (lower PC1 and higher PC2). Any shift in this direction will make seston, suspended sediment, WWTF effluent particulate, periphyton, duckweed, and bryozoan less similar to bed sediments.

- Increasing amounts of phytoplankton are associated with increasingly negative $\delta^{13} \mathrm{C}$ and positive $\delta^{15} \mathrm{~N}$ and, therefore, cannot be a major source to bed sediment. The bed sediment samples from late-summer-1999 from downstream of RM 26.9 shift slightly toward increasing phytoplankton, indicating that phytoplankton probably contributes a small amount of organic material to bed sediment during certain times in the lower reaches of the river.

- Suspended sediment and seston have similar characteristics, with seston showing an increased influence from phytoplankton. Some suspended sediment samples are similar to bed sediment and soil, but others are clearly affected by the presence of phytoplankton.

Table 5. Results of principal components analysis.

\begin{tabular}{|c|c|c|c|c|c|c|c|c|}
\hline \multirow{2}{*}{$\begin{array}{l}\text { Principal } \\
\text { component }\end{array}$} & \multirow{2}{*}{$\begin{array}{c}\text { Proportion } \\
\text { of variance } \\
\text { (percent) }\end{array}$} & \multicolumn{3}{|c|}{$\begin{array}{l}\text { Eigenvectors } \\
\text { (loadings) }\end{array}$} & \multicolumn{4}{|c|}{$\begin{array}{l}\text { Equation to calculate } P C \text { using original units } \\
\qquad \mathbf{P C}_{i}=\mathbf{A}_{i}{ }^{*} \delta^{13} \mathbf{C}+\mathbf{B}_{\mathrm{i}}{ }^{*} \delta^{15} \mathbf{N}+\mathbf{C}_{\mathrm{i}}{ }^{*} \mathbf{C} / \mathbf{N}+\mathbf{D}_{\mathrm{i}}\end{array}$} \\
\hline & & $\delta^{13} \mathrm{C}$ & $\delta^{15} \mathrm{~N}$ & $\mathrm{C} / \mathrm{N}$ & $A_{i}$ & $B_{i}$ & $C_{i}$ & $D_{i}$ \\
\hline $1(\mathrm{PC} 1)$ & 64 & 0.529 & -0.619 & 0.580 & 0.1545 & -0.1876 & 0.03455 & 5.01 \\
\hline $2(\mathrm{PC} 2)$ & 22 & 0.811 & 0.169 & -0.560 & 0.2369 & 0.05119 & -0.03332 & 7.33 \\
\hline
\end{tabular}


The principal components plot also enables a qualitative examination of the effect of mixing several sources. For example, a mixture of WWTF effluent particulate and terrestrial plant litter mathematically could lead to the observed bed sediment pattern. This mixture, however, is not realistic because not all bed sediments were collected downstream of WWTFs. In general, the bed sediment samples plot in a region that makes it unlikely that extensive mixtures of the potential source substances could account for the $\delta^{13} \mathrm{C}$, $\delta^{15} \mathrm{~N}$, and $\mathrm{C} / \mathrm{N}$ values of bed sediment. Bed sediment samples plot farther to the upper right than most of the potential source materials except soil and two unusual periphyton samples. Erosional and transport processes throughout the drainage basin make soil a likely potential source of organic matter in bed sediment. The possibility that some unusual types of periphyton could be present in sufficient quantity to create a mixture resembling bed sediment, however, is remote.

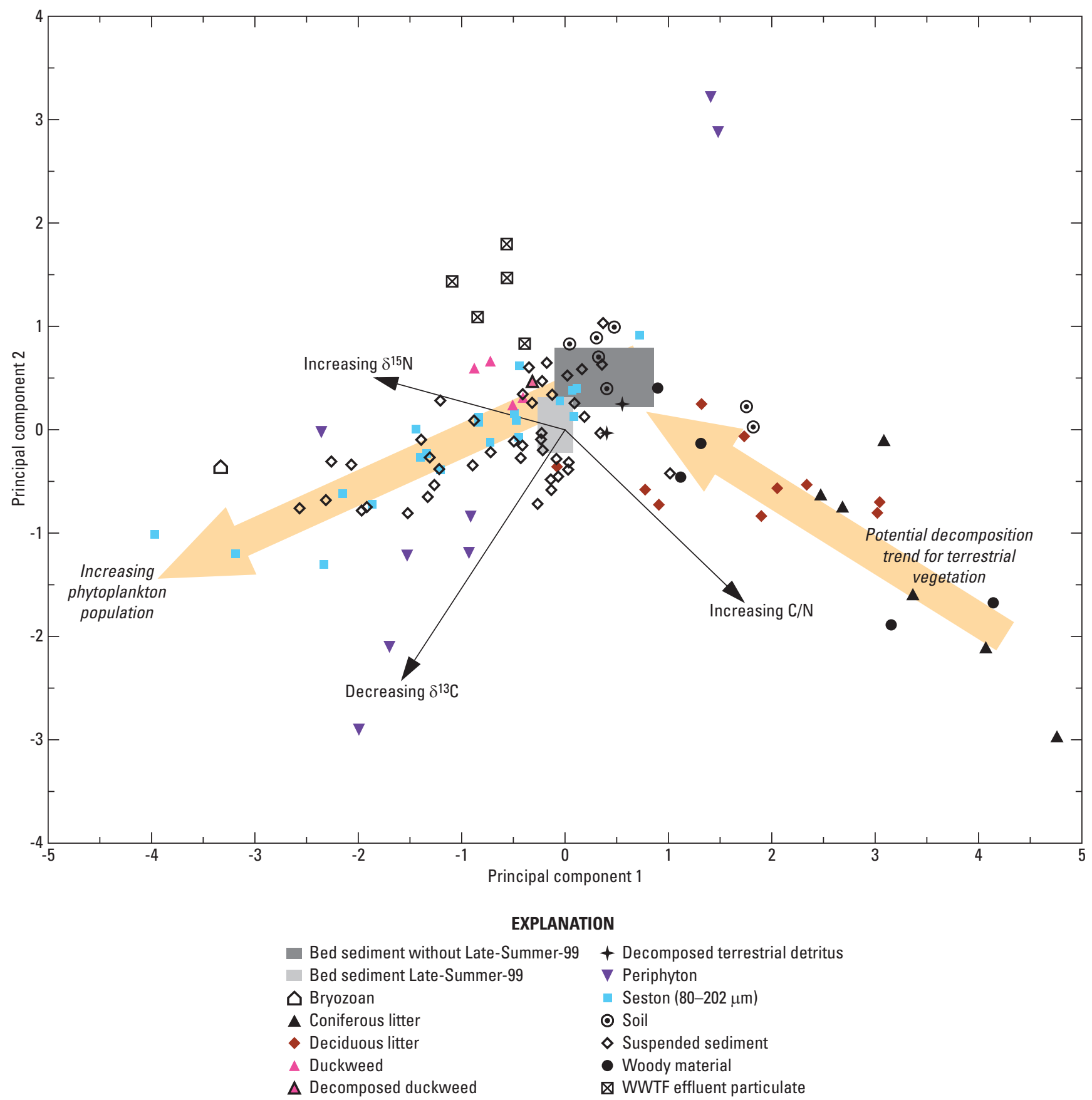

Figure 14. Results of a principal components analysis of $\delta^{13} \mathrm{C}, \delta^{15} \mathrm{~N}$, and $\mathrm{C} / \mathrm{N}$ data for samples taken from the Tualatin River basin, Oregon. [WWTF=Wastewater Treatment Facility]. 


\section{Summary and Conclusions}

Isotopic composition of carbon and nitrogen and $\mathrm{C} / \mathrm{N}$ ratios were used to assess the potential contribution of various sources of organic matter to bed sediment in the Tualatin River. Samples of bed sediment, suspended sediment, and seston (suspended particulate material, including plankton and organic detritus) in the Tualatin River were collected during five sampling events in 1998-2000. During the same time period, potential source materials such as soil, plant litter, duckweed, and wastewater treatment facility effluent particulate were collected for comparison of their isotopic composition.

Bed sediment $\delta^{15} \mathrm{~N}$ was slightly lower in tributaries and in the upper reaches of the river and may indicate that the organic matter in these areas is fresher, less decomposed, or more labile. Higher SOD rates have been measured in the tributaries compared to the main stem Tualatin River, supporting the hypothesis that this material may be more labile. No general trends in $\delta^{13} \mathrm{C}$ or $\mathrm{C} / \mathrm{N}$ for bed sediment with river location were observed. Bed sediment in the lower river, which is associated with the most phytoplankton growth, was not usually different from bed sediment farther upstream where less algae is present. Bed sediment collected from the lower river in late summer (1999), however, did show a small difference, a likely influence of phytoplankton.

Phytoplankton was evident in seston and suspended sediment samples and characterized by low $\delta^{13} \mathrm{C}(<-32$ per mil), high $\delta^{15} \mathrm{~N}(>8$ per mil), and low $\mathrm{C} / \mathrm{N}(<12)$. The increasing amount of phytoplankton in the more downstream river samples was reflected in distinct trends in the isotopic data and $\mathrm{C} / \mathrm{N}$ ratios with river mile. The isotopic data for samples that contained the most phytoplankton did not resemble bed sediment. Decomposition of organic matter tends to decrease the $\mathrm{C} / \mathrm{N}$ ratio and increase the $\delta^{15} \mathrm{~N}$ value, further increasing the differences compared to bed sediment. Therefore, phytoplankton likely is not a major source of organic matter to bed sediment. Reductions in the size of the algal community, therefore, may have little effect on the rate of sediment oxygen demand.

Compared to bed sediment, the nitrogen content was heavier (higher $\delta^{15} \mathrm{~N}$ ) and/or the $\mathrm{C} / \mathrm{N}$ ratio was lower for several types of samples, including duckweed, periphyton and wastewater treatment facility effluent particulate. Further decomposition of these materials would tend to increase the $\delta^{15} \mathrm{~N}$ and decrease the $\mathrm{C} / \mathrm{N}$, increasing their differences compared to bed sediment. It is, therefore, unlikely that duckweed, periphyton, or wastewater treatment facility effluent are significant sources of organic matter to bed sediment. Periphyton samples exhibited $\delta^{13} \mathrm{C}$ values that spanned the widest range of any of the types of samples collected for this study; the inconsistency of the $\delta^{13} \mathrm{C}$ of periphyton limits the use of $\delta^{13} \mathrm{C}$ as a tracer for this class of sample.
The $\delta^{13} \mathrm{C}, \delta^{15} \mathrm{~N}$, and $\mathrm{C} / \mathrm{N}$ for samples of soil and decomposed terrestrial organic matter closely resembled results for bed sediments. Although soil may be a direct source of organic matter to bed sediment, terrestrial plant material likely is a source of organic matter to both bed sediments and soils. Deciduous litter, woody material, and coniferous litter have $\delta^{13} \mathrm{C}$ values that match soils and bed sediments well. Although the $\delta^{15} \mathrm{~N}$ and $\mathrm{C} / \mathrm{N}$ ratios for fresh leaf litter and twigs do not match the $\delta^{15} \mathrm{~N}$ and $\mathrm{C} / \mathrm{N}$ ratios for soils and bed sediments, decomposition of those materials is expected to shift the $\delta^{15} \mathrm{~N}$ and $\mathrm{C} / \mathrm{N}$ toward those of bed sediment, resulting in a good match. Furthermore, the basin produces a considerable quantity of terrestrial plant litter which easily is transported to the stream network. It is consistent to conclude, therefore, that soil and leaf litter probably are the primary sources of organic matter to Tualatin River bed sediment. Monitoring and management plans that aim to improve oxygen conditions in the river would be most successful by concentrating on sources of soil, leaf litter, and other terrestrially derived organic materials to the river rather than on the instream growth of algae.

\section{Acknowledgments}

The authors thank the following people for their contributions to this work: Chauncey Anderson, Amy Brooks, Kurt Carpenter, Micelis Doyle, Wes Jarrell, Matt Johnston, and Tammy Wood for assistance in sample collection; Renate Ryan for assistance in not only sample collection but also processing and freeze-drying; Carol Kendall and the graduate and post-doctoral students in her stable isotopes laboratory for the many hours spent analyzing samples from this study and their help in interpreting the laboratory data; and Jan Miller of Clean Water Services for helping to organize and fund the project. Finally, the authors are grateful to the group of reviewers that provided helpful comments on this report.

\section{References Cited}

Bernasconi, S.M., Barbieri, A., and Simona, M., 1997, Carbon and nitrogen isotope variations in sedimenting organic matter in Lake Lugano: Limnology and Oceanography, v. 42 , no. 8 , p. $1955-1765$.

Edwards, T.K., and Glysson, G.D., 1999, Field methods for measurement of fluvial sediment: U.S. Geological Survey Techniques of Water-Resources Investigations, book 3, chap. C2, 89 p. 
Finlay, J.C., and Kendall, C., 2007, Stable isotope tracing of temporal and spatial variability in organic matter sources to freshwater ecosystems, in Michener, R.H., and Lajtha, K., eds., Stable Isotopes in Ecology and Environmental Science (2d ed.): Hoboken, N.J., Wiley-Blackwell, p. 283-333.

Helsel, D.R., and Hirsch, R.M., 1992, Statistical methods in water resources: Amsterdam, Elsevier Science Publishers, $522 \mathrm{p}$.

Homer, C., Dewitz, J., Fry, J., Coan, M., Hossain, N., Larson, C., Herold, N., McKerrow, A., VanDriel, J.N., and Wickham, J., 2007, Completion of the 2001 National Land Cover Database for the conterminous United States: Photogrammetric Engineering and Remote Sensing, v. 73, no. 4 , p. 337-341.

Kendall, C., Silva, S.R., and Kelly, V.J., 2001, Carbon and nitrogen isotopic compositions of particulate organic matter in four large river systems across the United States: Hydrological Processes, v. 15, no. 7, 1301-1346. (Also available at http://dx.doi.org/10.1002/hyp.216.)

Middelburg, J.J., and Nieuwenhuize, J., 1998, Carbon and nitrogen stable isotopes in suspended matter and sediments from the Schelde Estuary: Marine Chemistry, v. 60, p. 217-225.

Miller, J.C., and Miller, J.N., 1988, Statistics for analytical chemistry ( $2 \mathrm{~d}$ ed.): New York, John Wiley and Sons, 227 p.
Oregon Department of Environmental Quality, 2001, Tualatin subbasin Total Maximum Daily Load (TMDL): Portland, Oregon, Oregon Department of Environmental Quality, 165 p., accessed October 8, 2009, at http://www.deq.state. or.us/wq/TMDLs/docs/willamettebasin/tualatin/tmdlwqmp. pdf.

Rounds, S.A., and Doyle, M.C., 1997, Sediment oxygen demand in the Tualatin River Basin, Oregon, 1992-1996: U.S. Geological Survey Water-Resources Investigations Report 97-4103, 19 p.

Rounds, S.A., Wood, T.M., and Lynch, D.D., 1999, Modeling discharge, temperature, and water quality in the Tualatin River, Oregon: U.S. Geological Survey Water-Supply Paper 2465-B, $121 \mathrm{p}$.

SAS Institute Inc., 1989, SAS/STAT ${ }^{\circledR}$ version 6.07.01, Cary, N.C.

Tualatin River Flow Management Technical Committee, 2000, Annual data report for 1999: Clean Water Services and Oregon Water Resources Department, accessed October 9, 2009, at http://www.co.washington.or.us/Watermaster/ SurfaceWater/upload/FlowReport-1999.pdf.

U.S. Census Bureau, 2000, State and County QuickFacts: U.S. Census Bureau website, accessed October 6, 2009, at http:// quickfacts.census.gov/qfd/states/41/41067.html. 


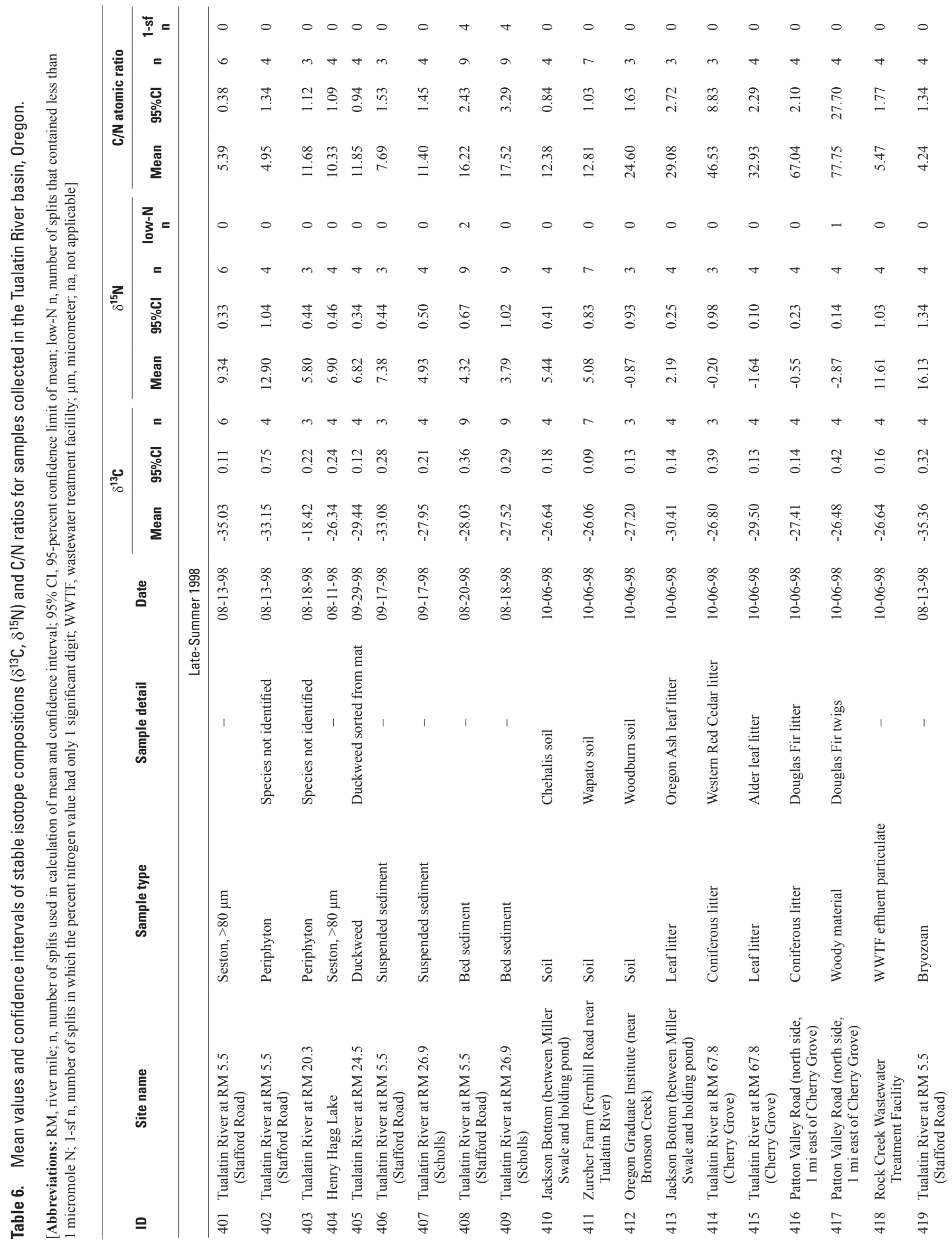


1000000

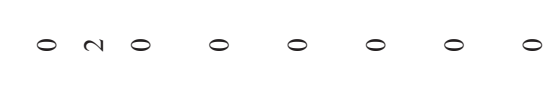

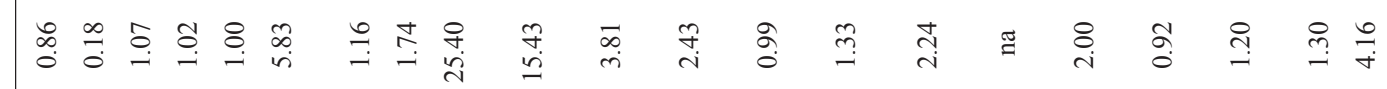

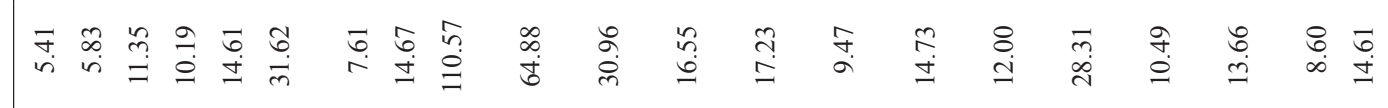

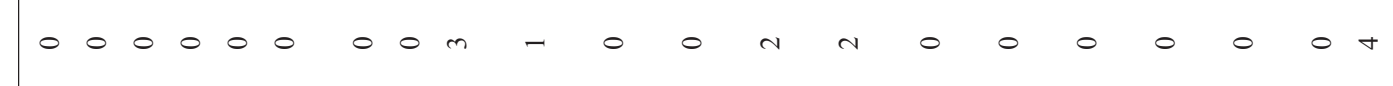

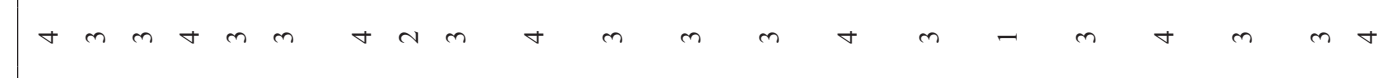

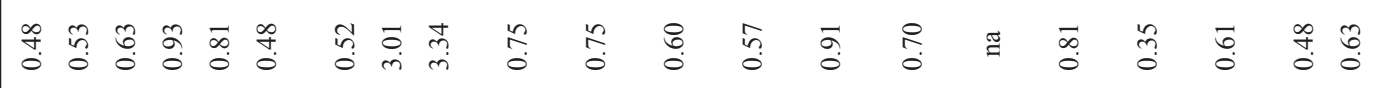

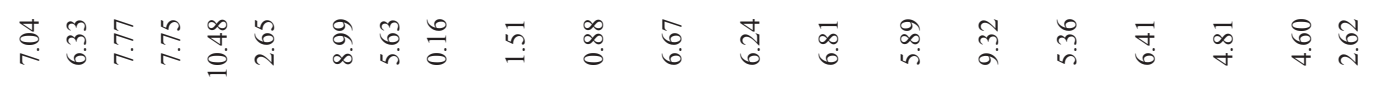

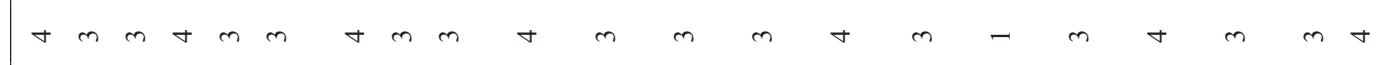

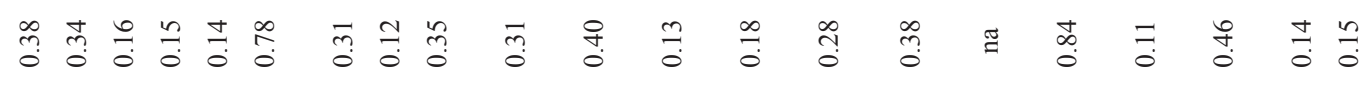

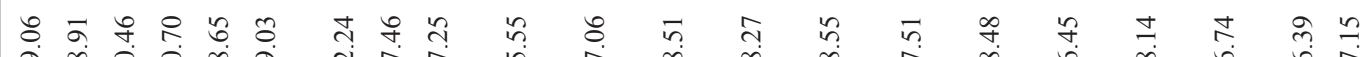

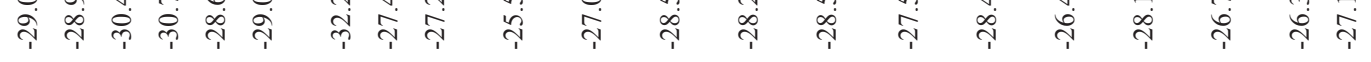

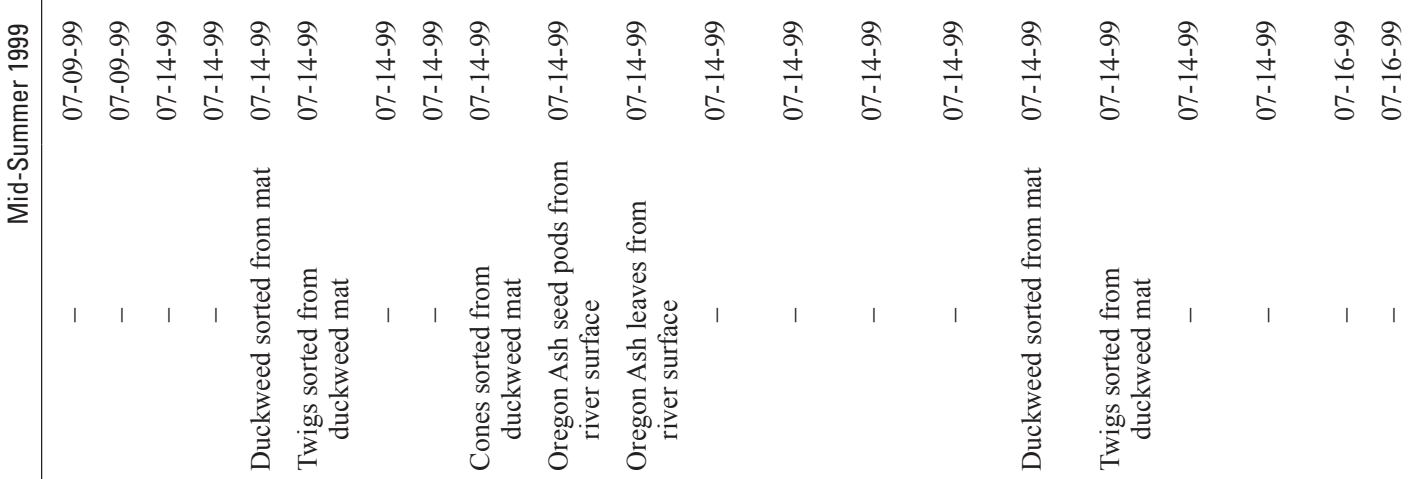

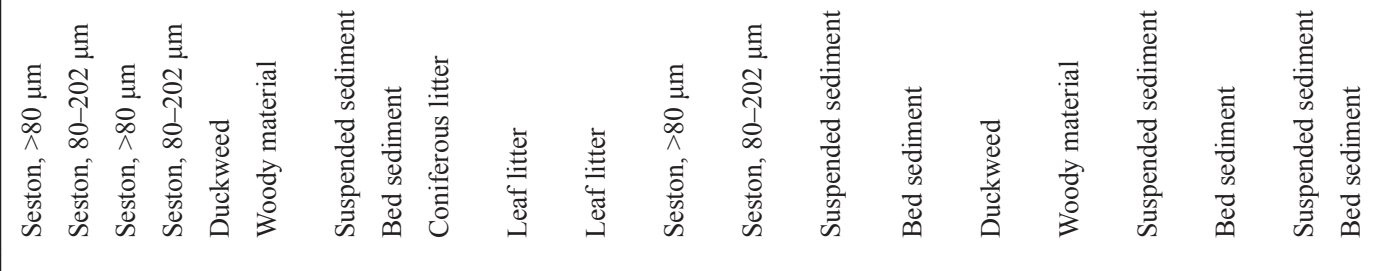

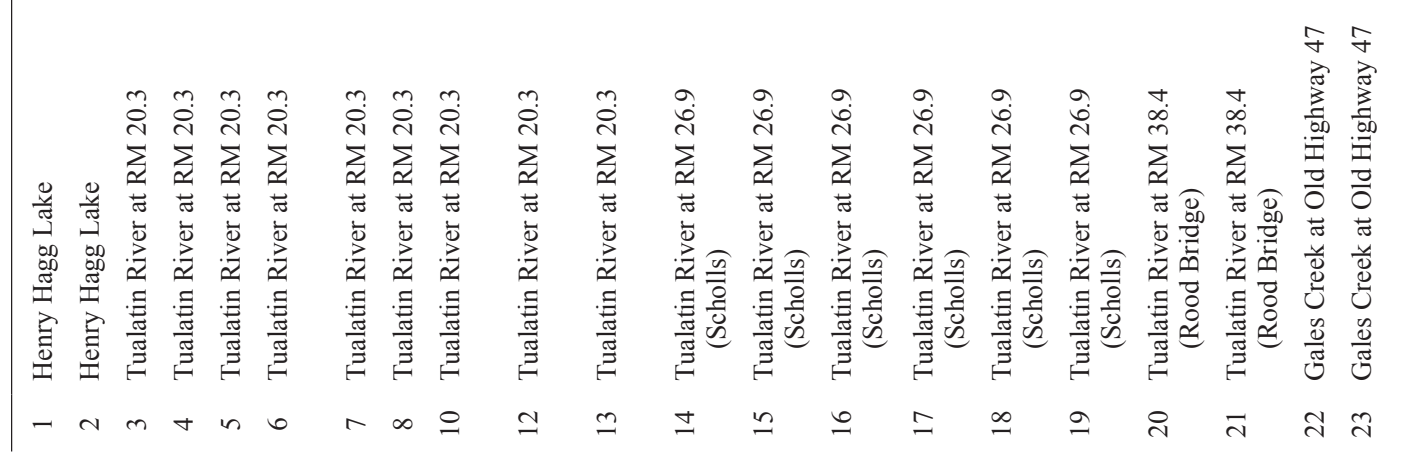




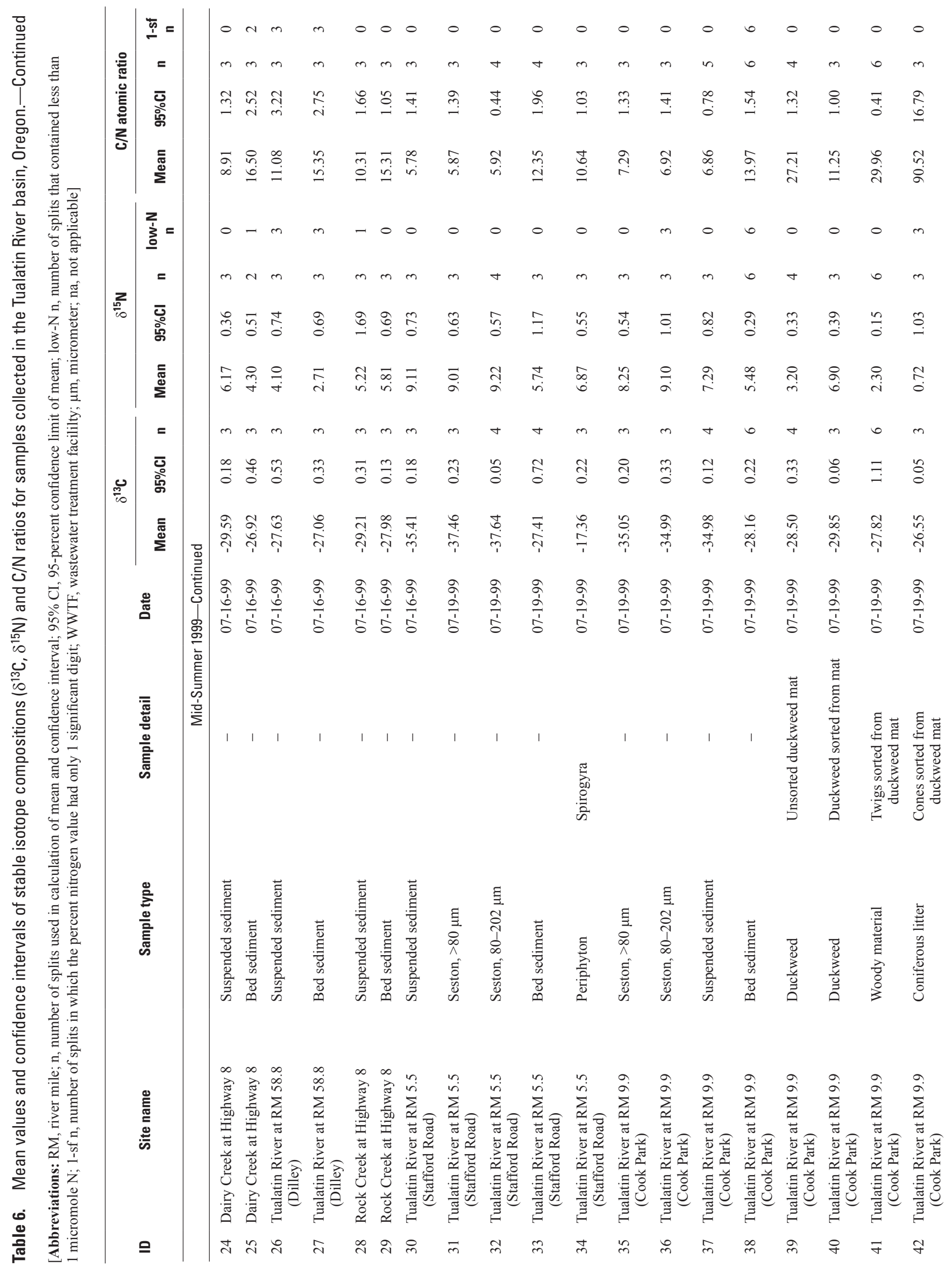




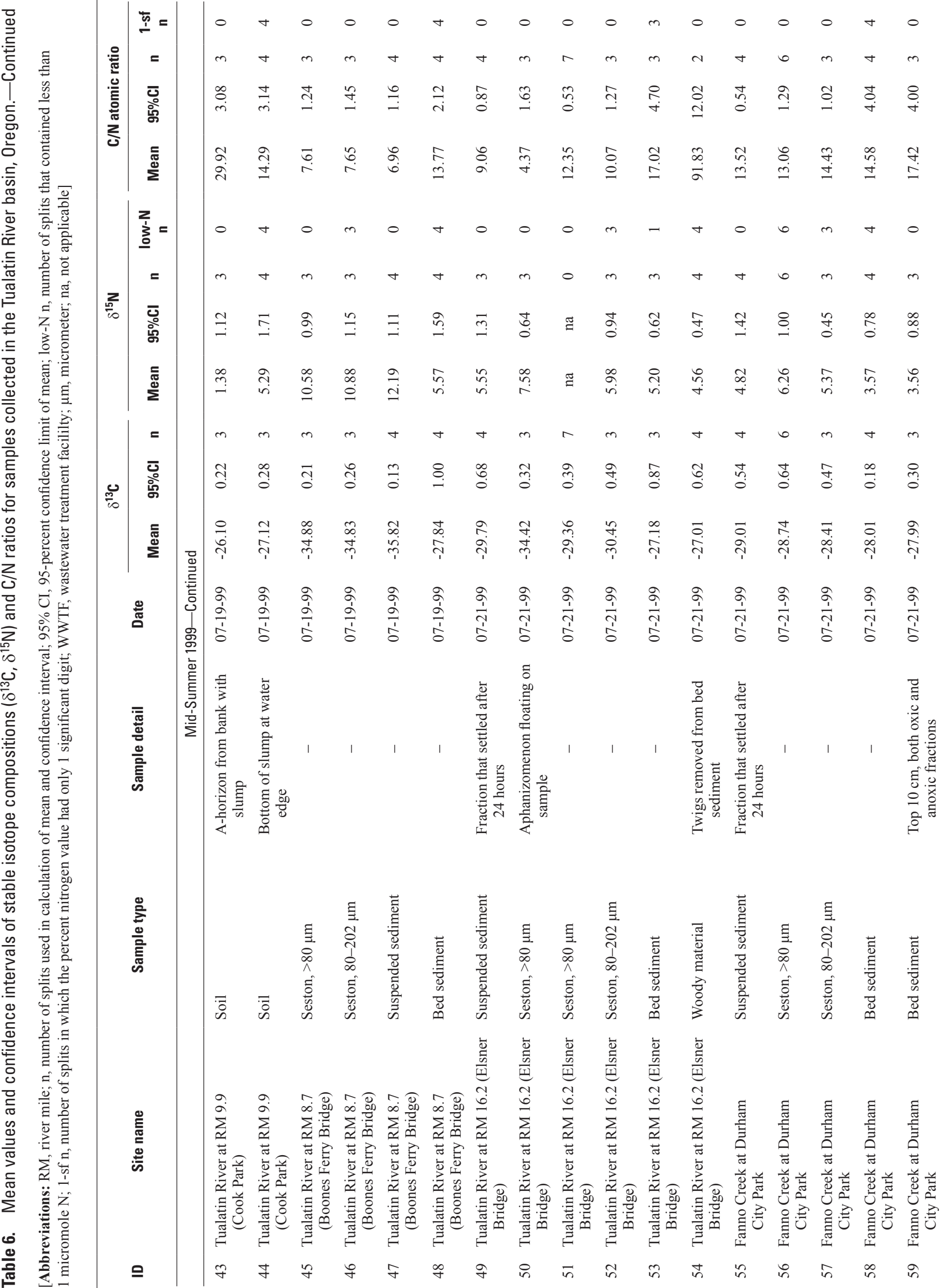




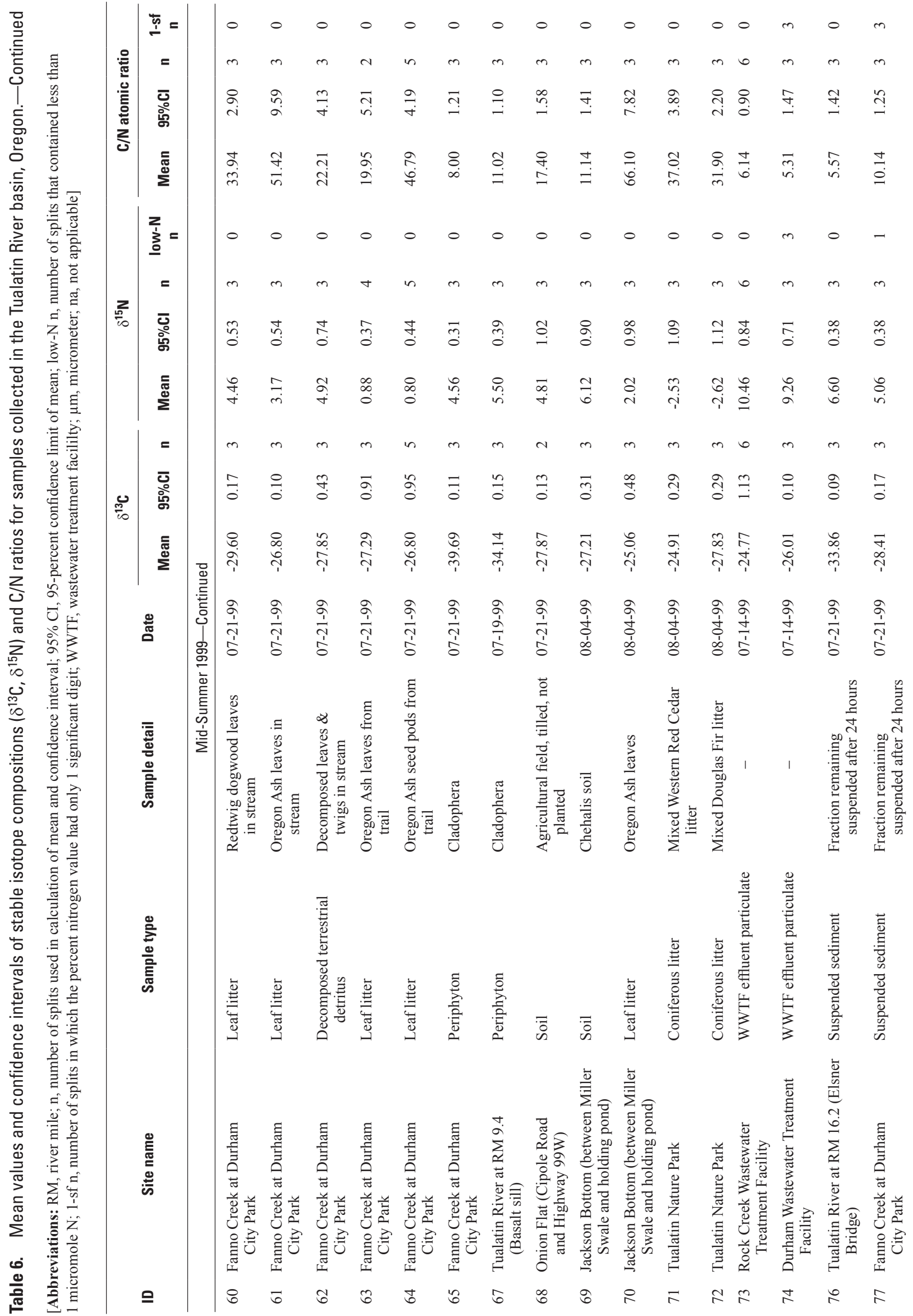



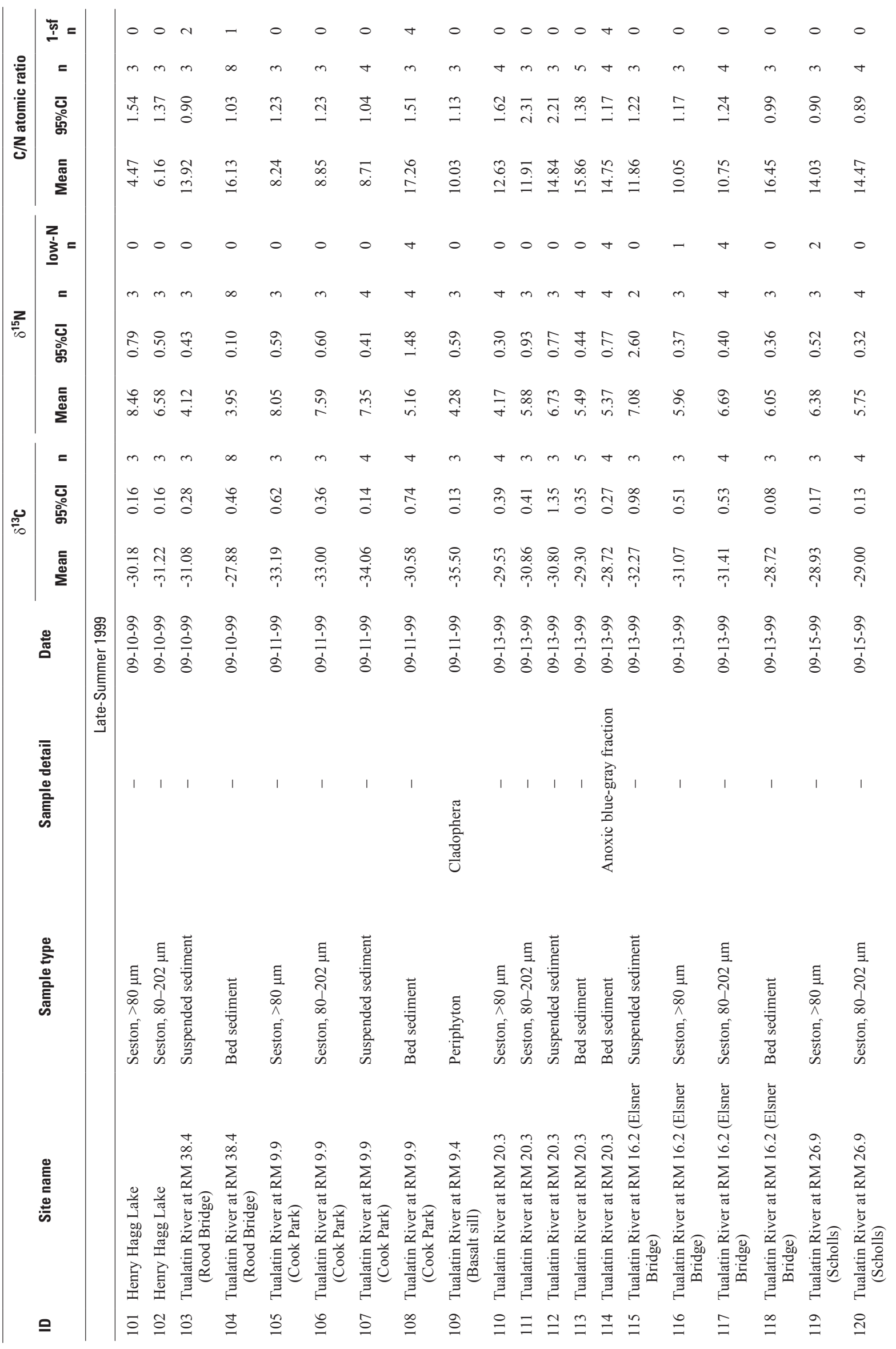


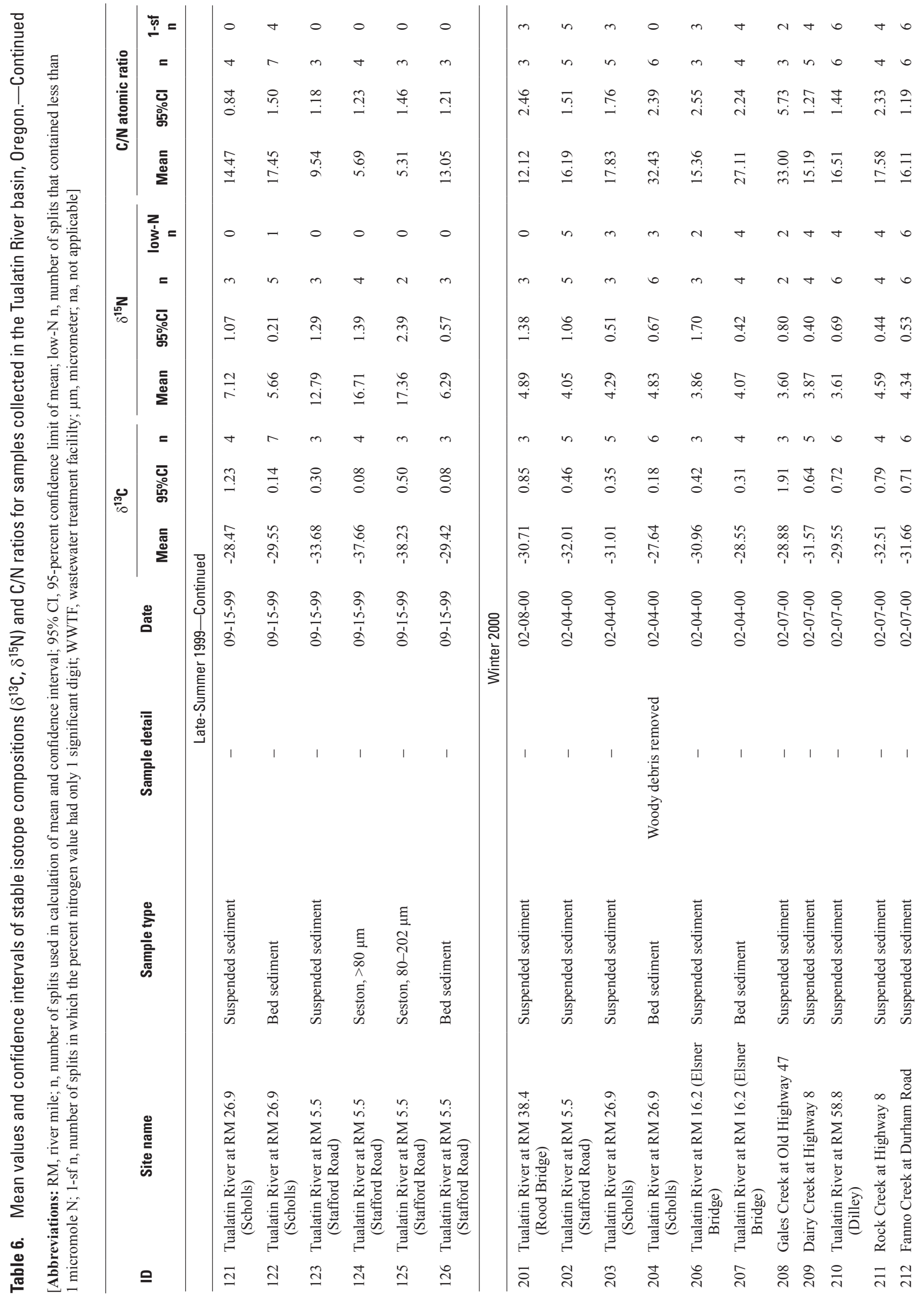




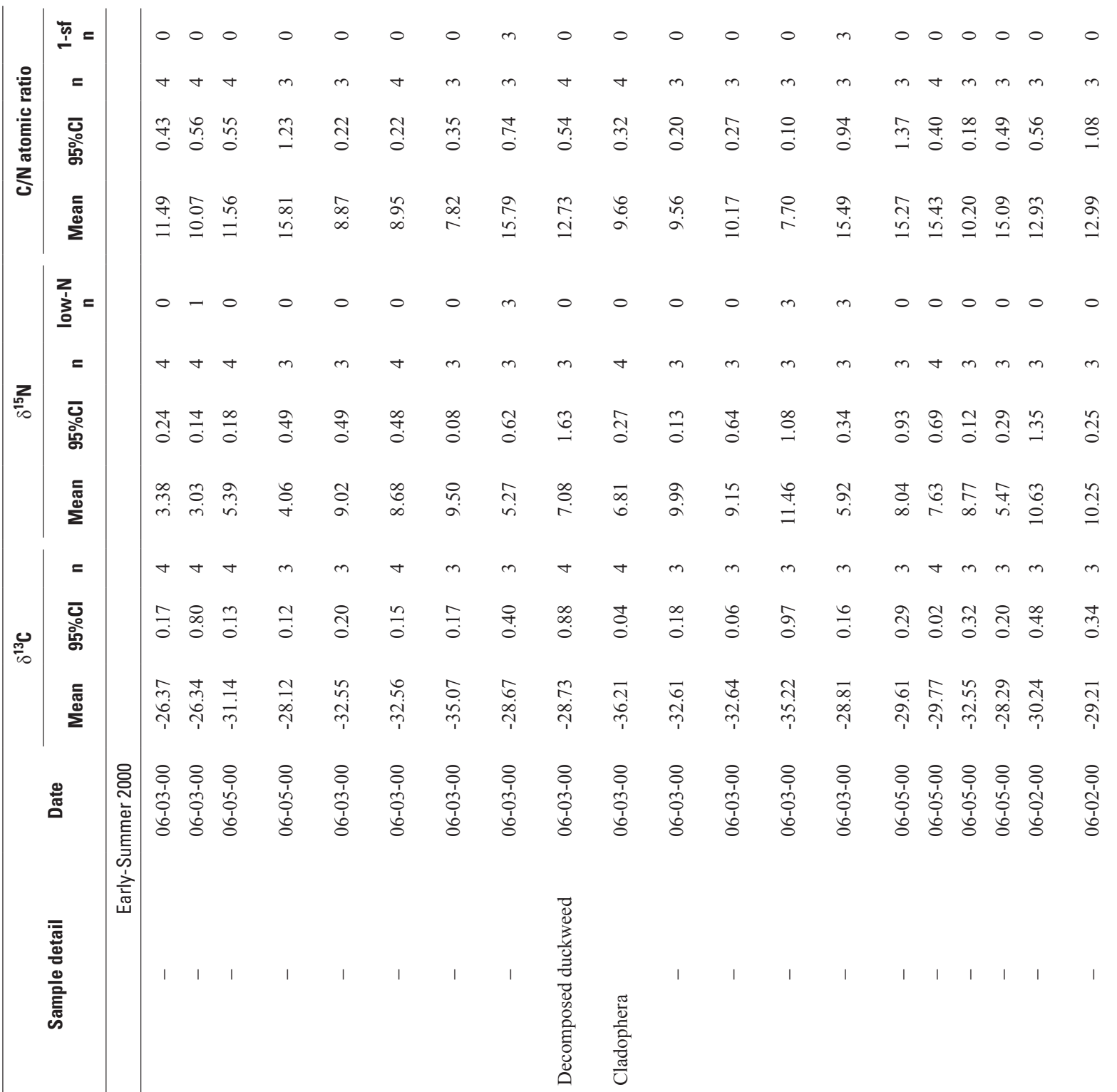

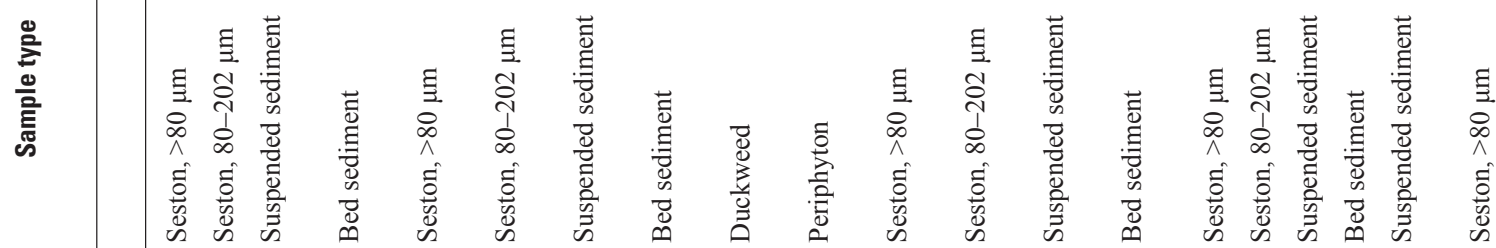

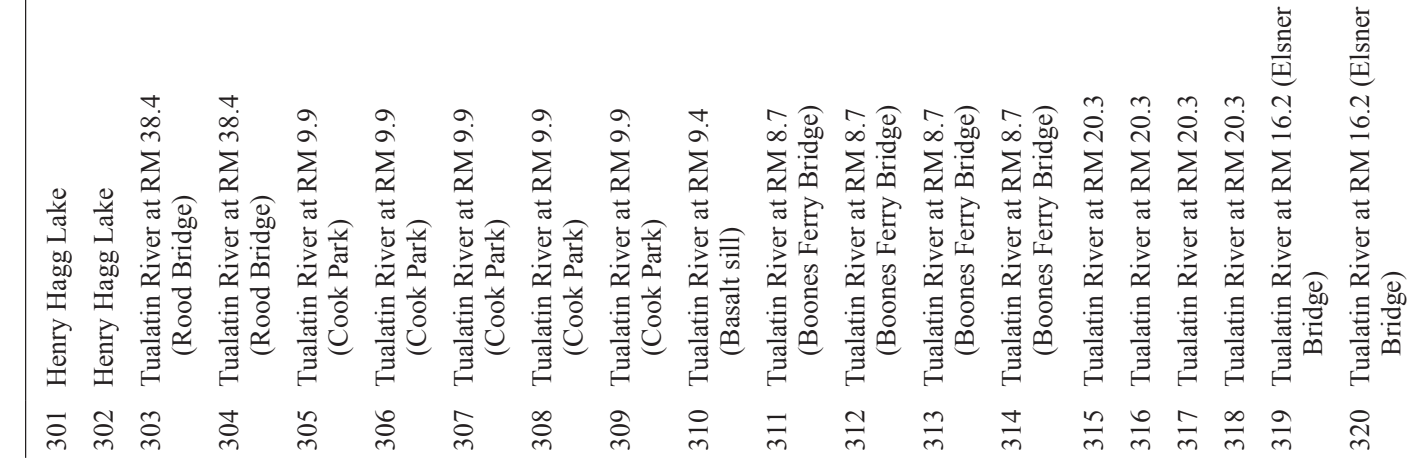




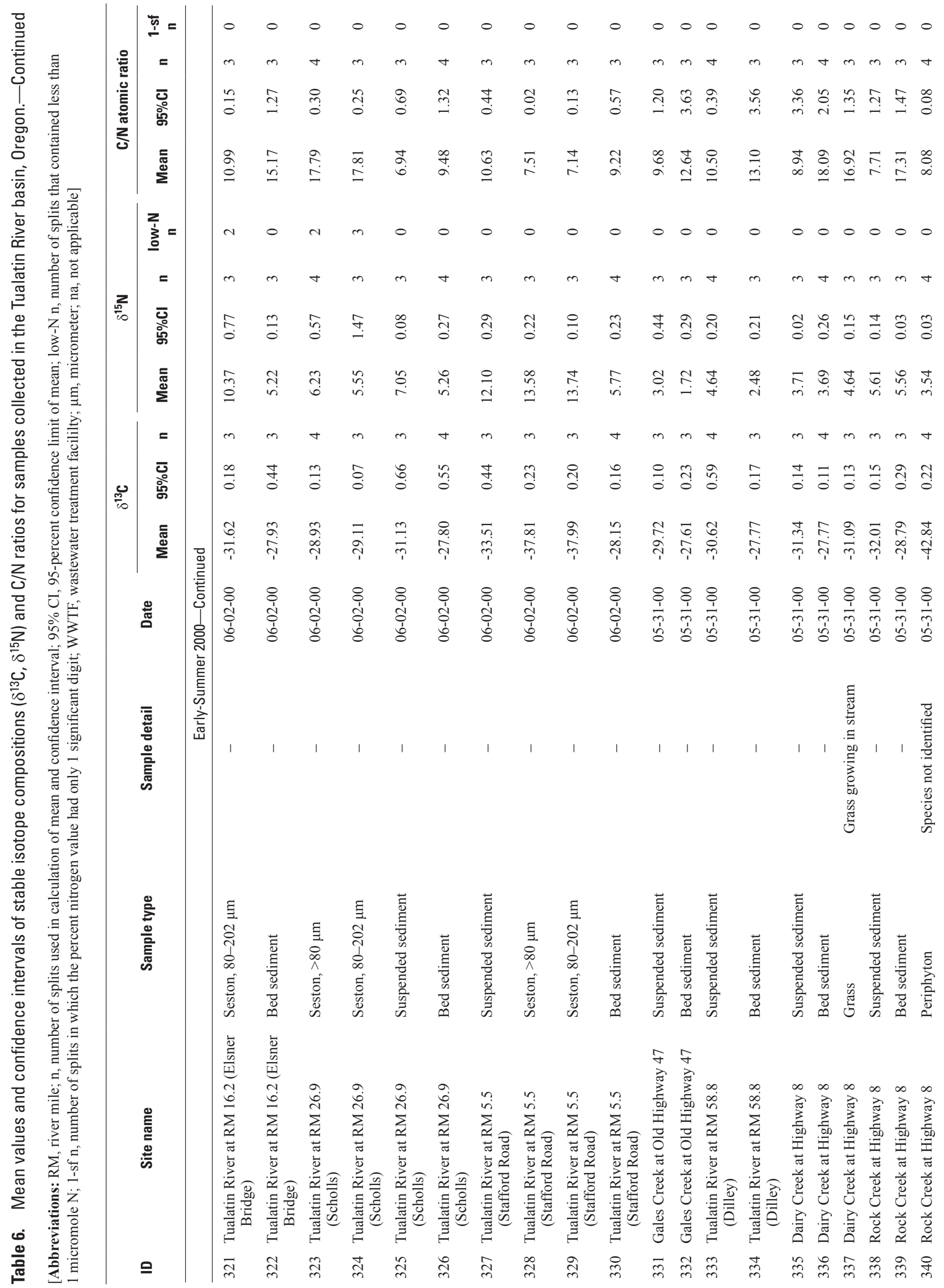




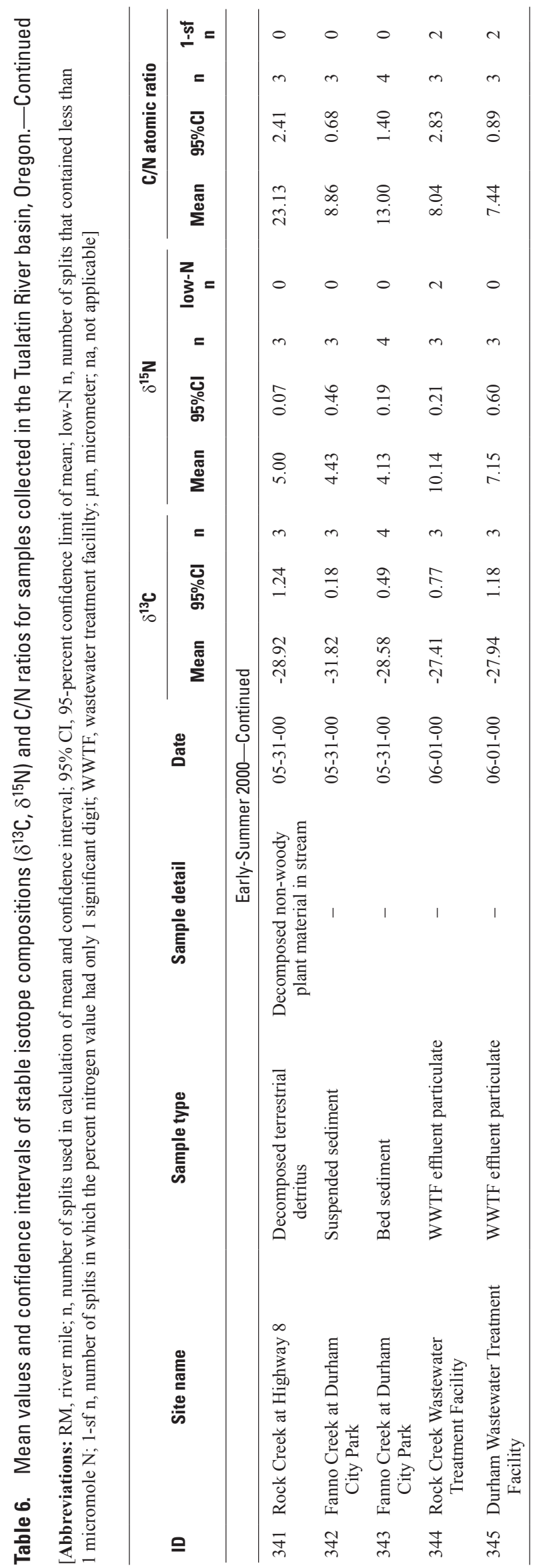


Appendix A. 


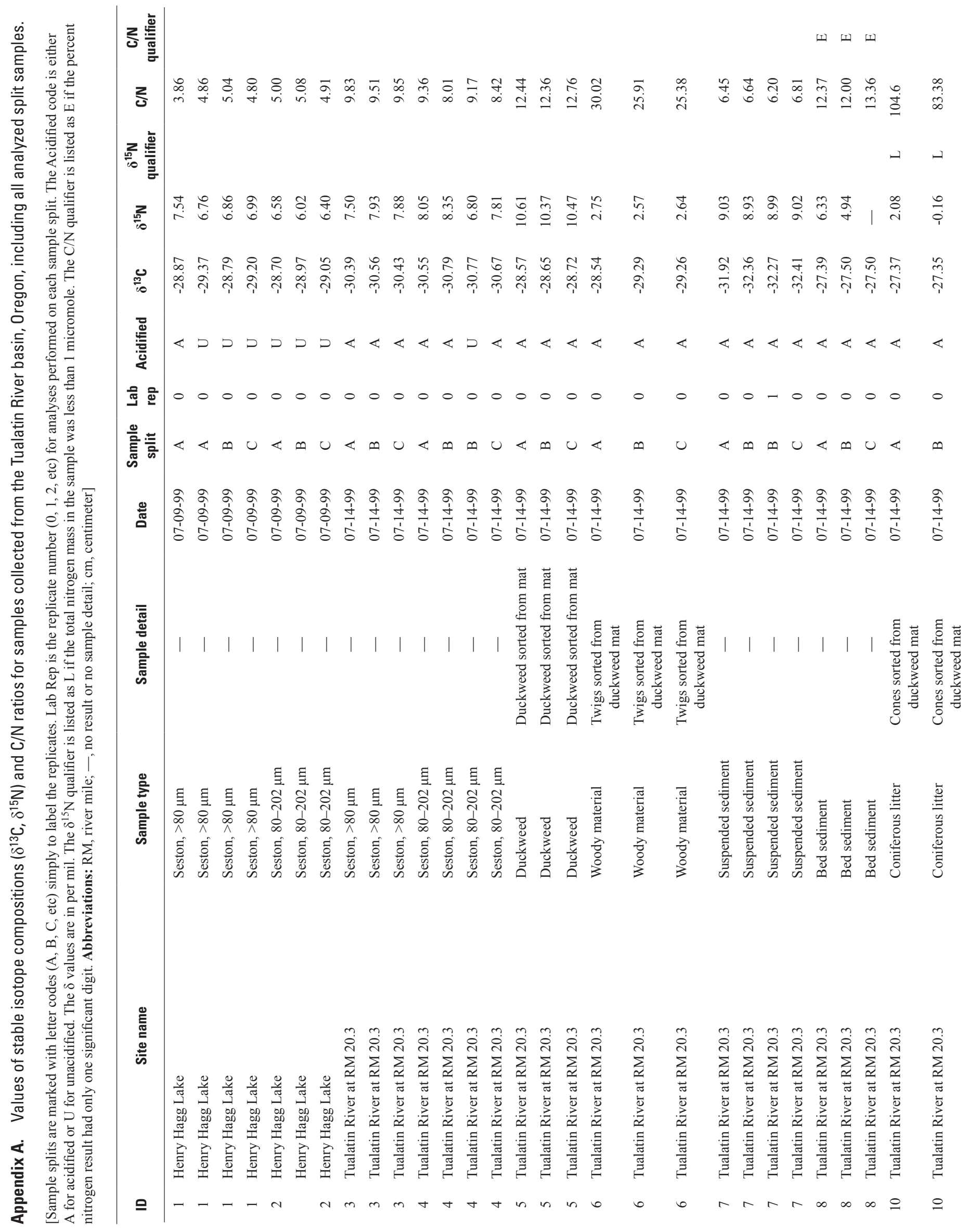




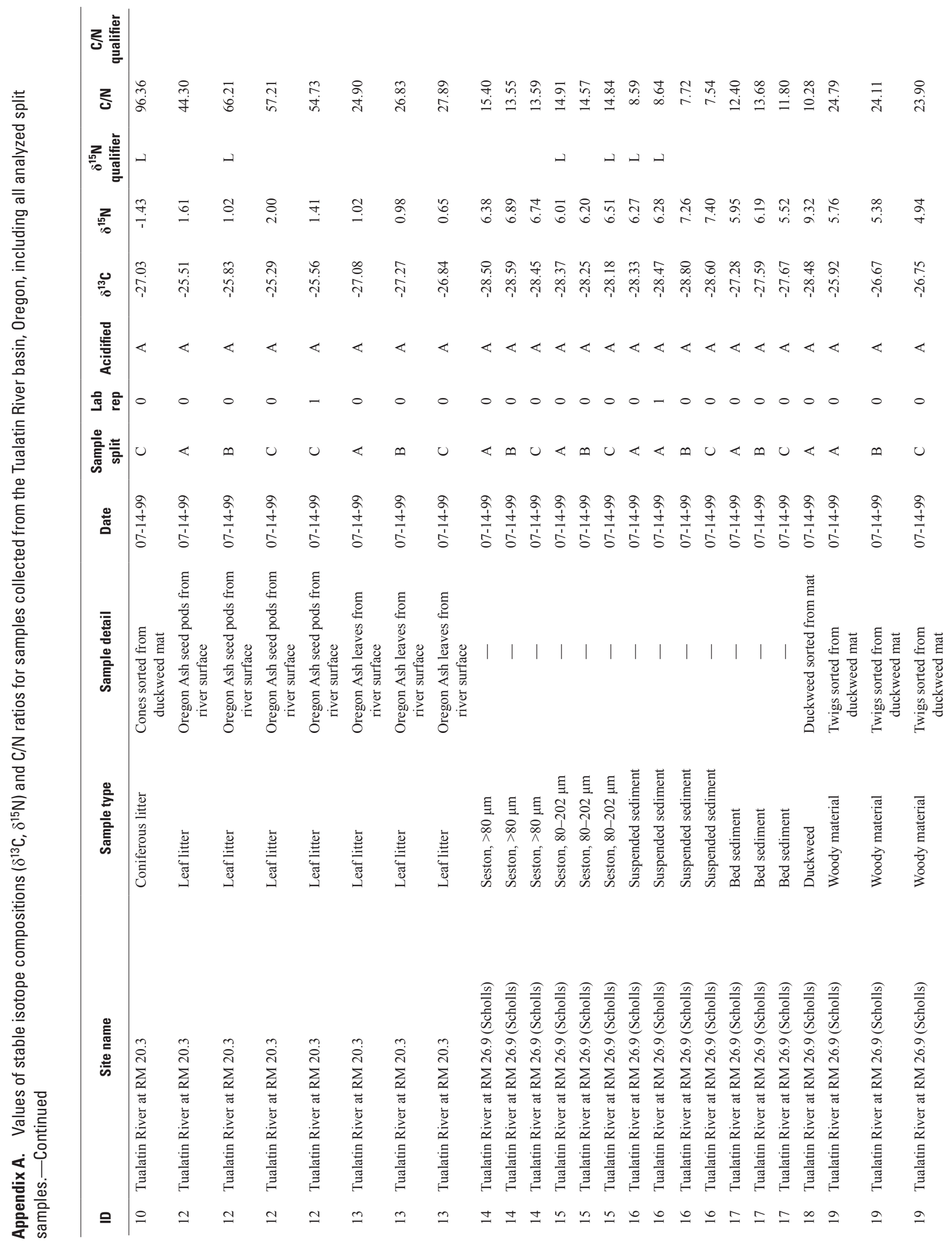




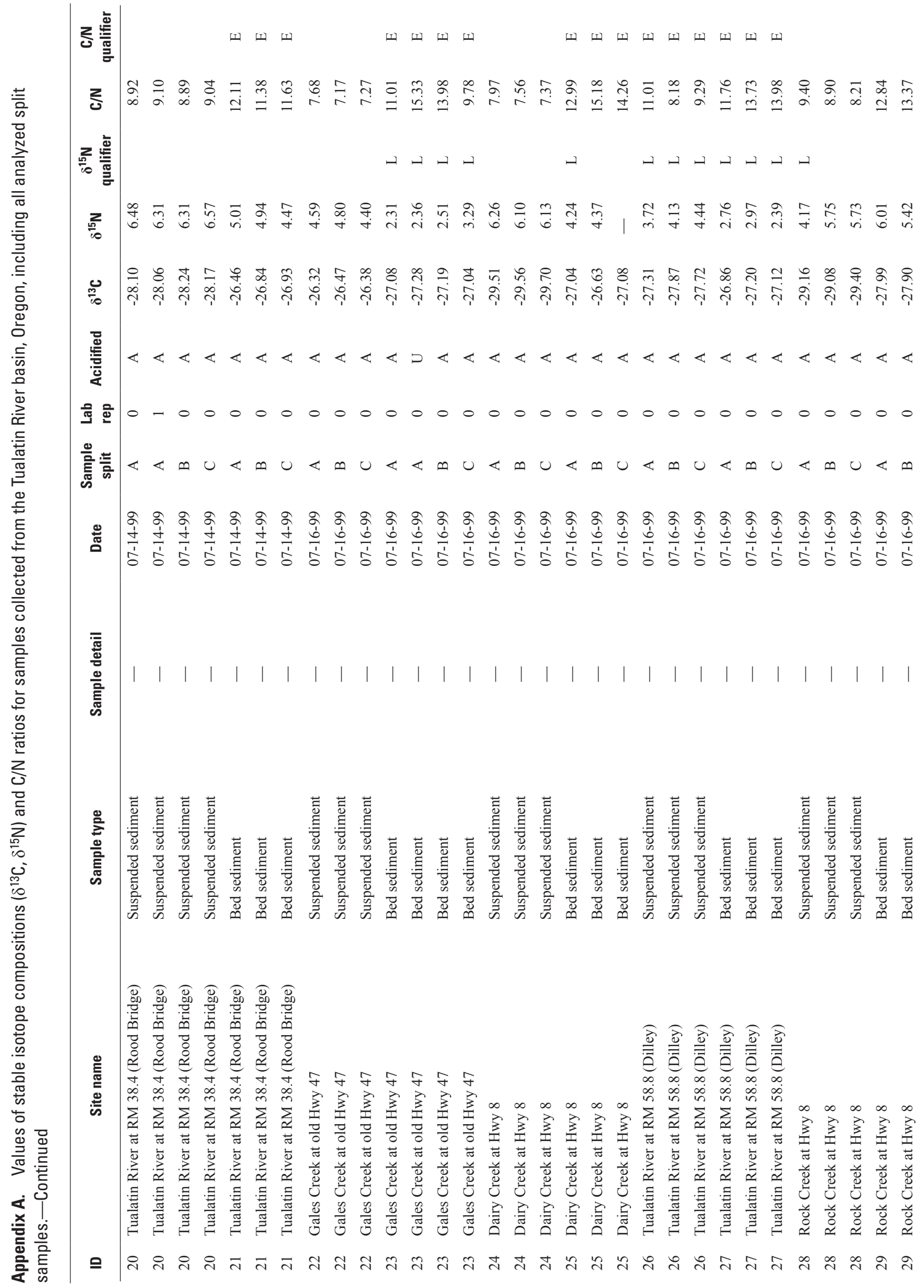




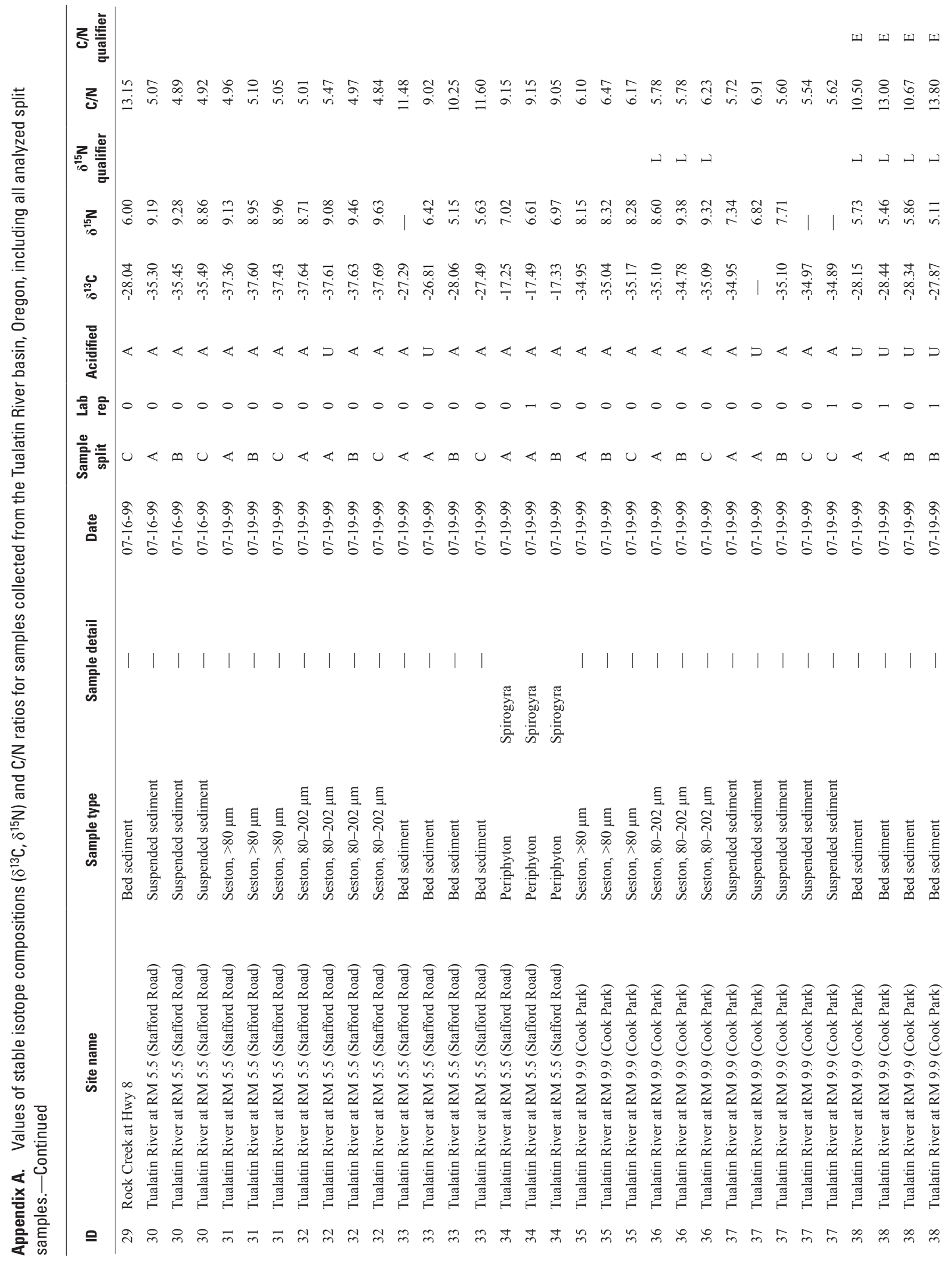




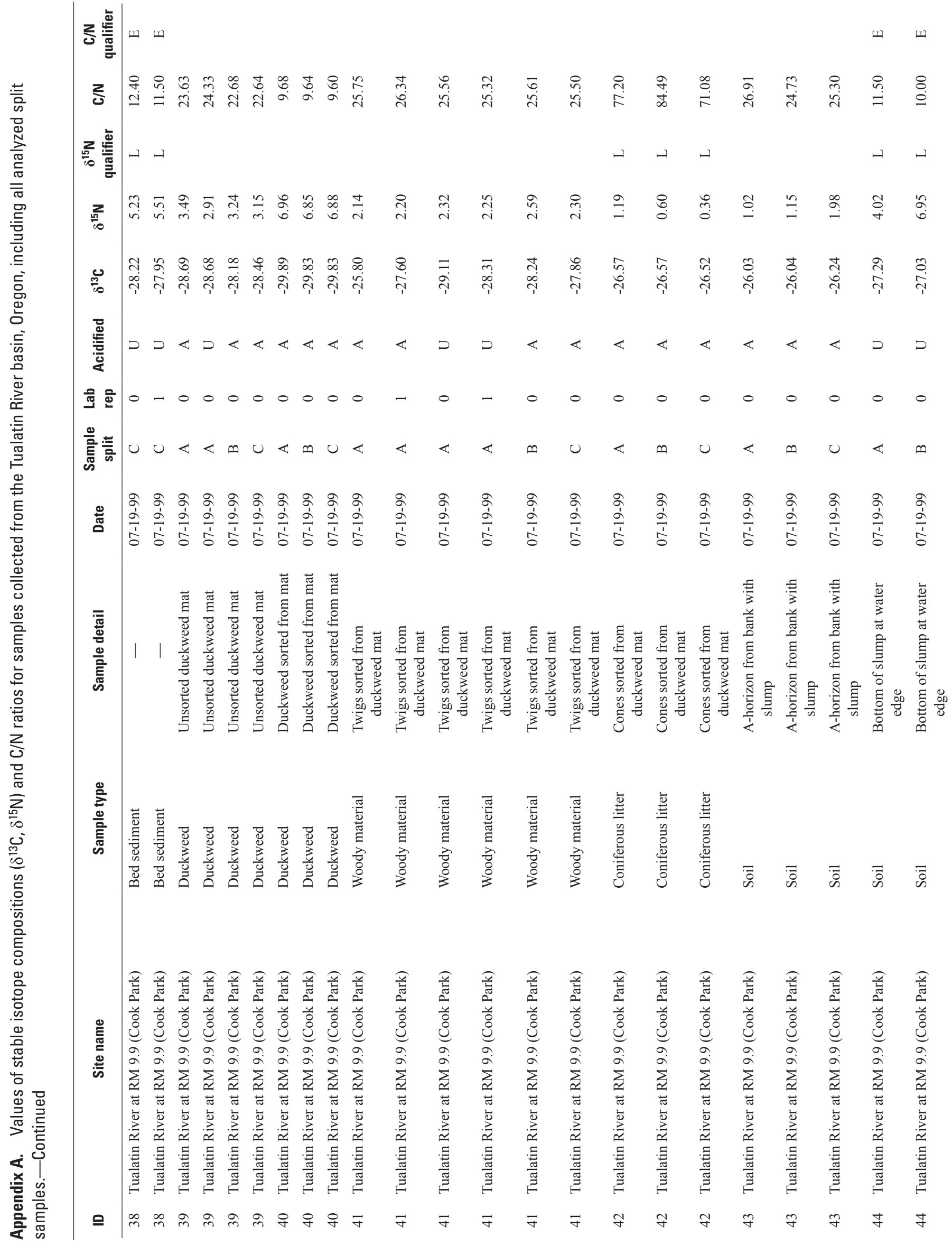




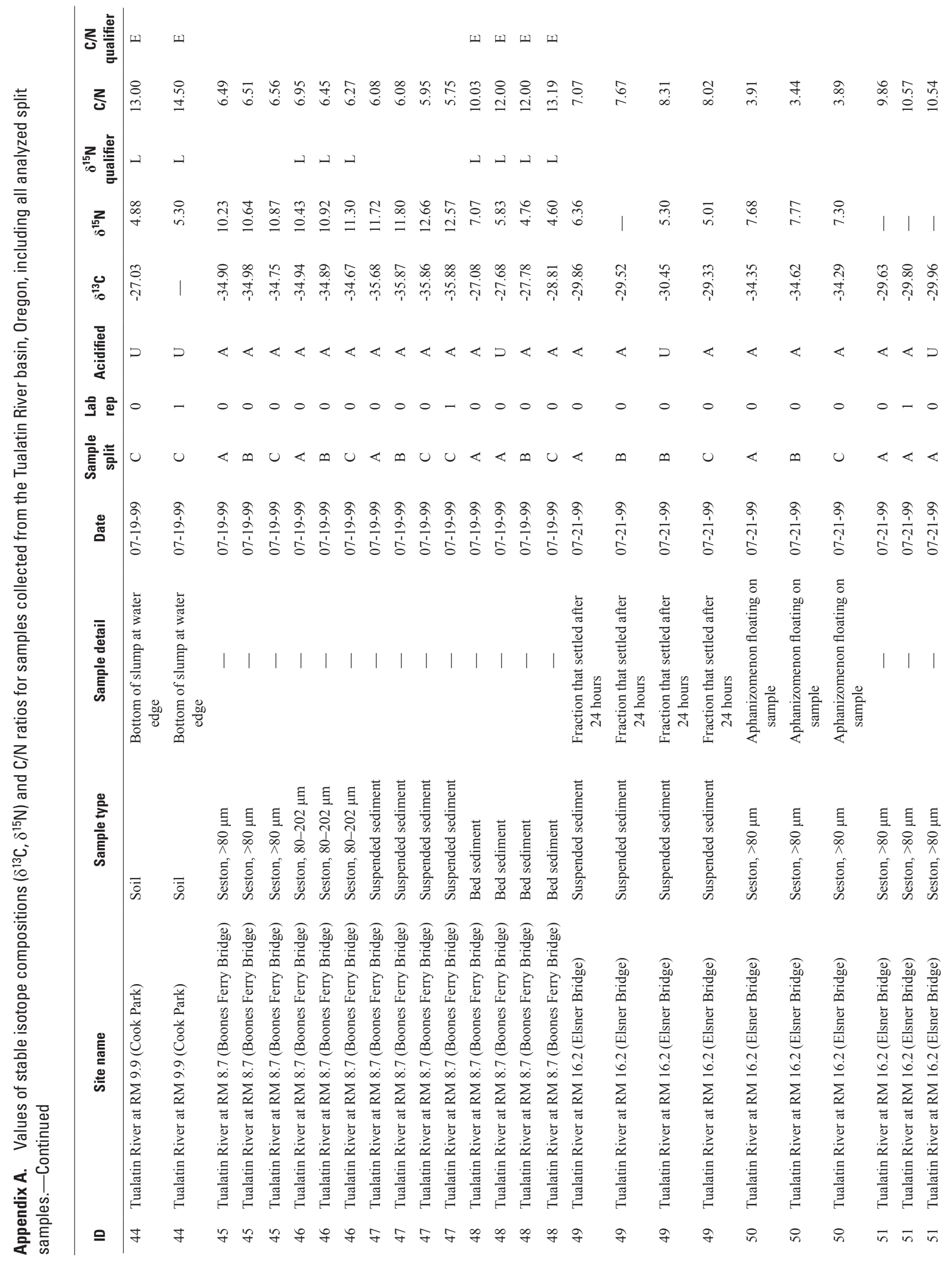




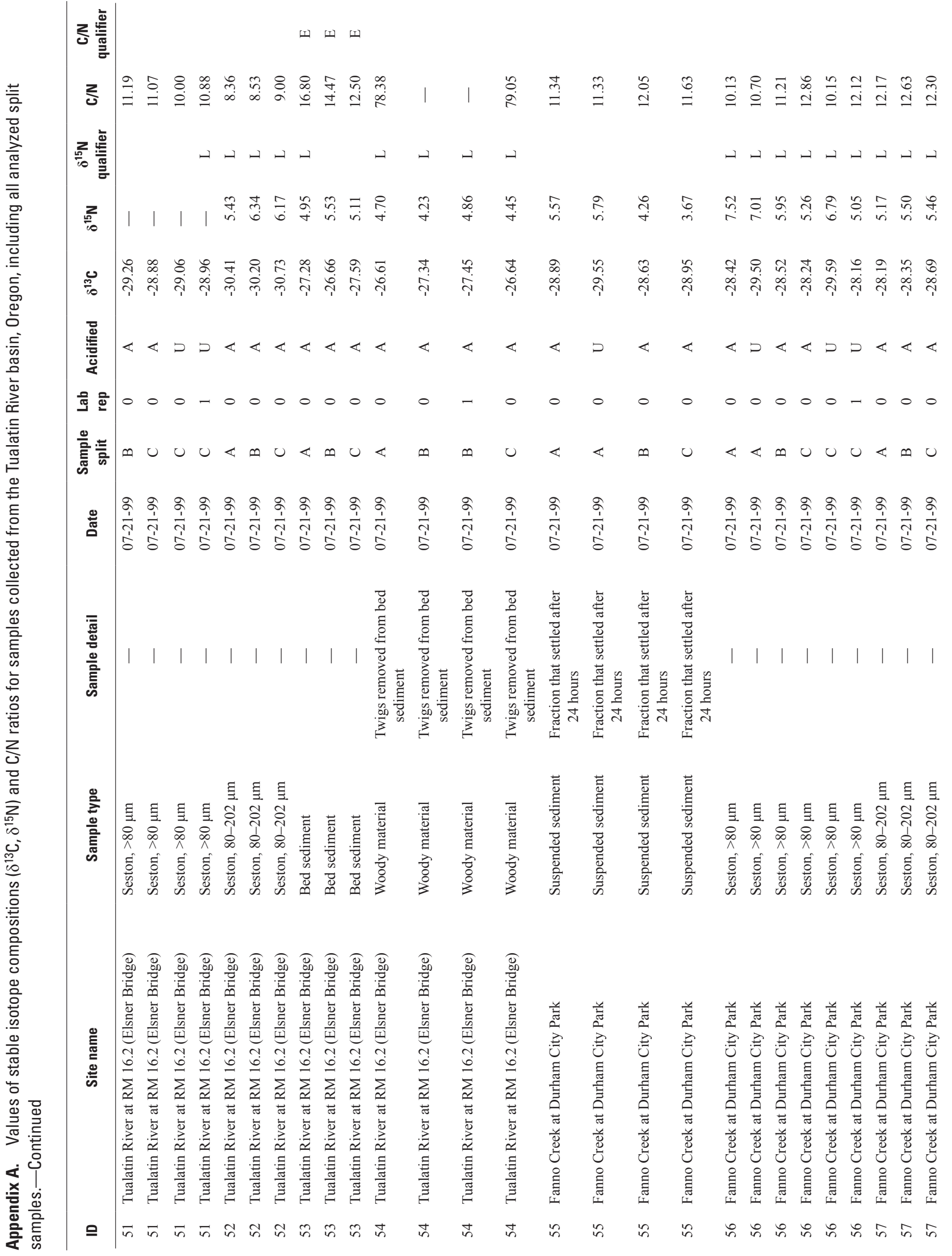




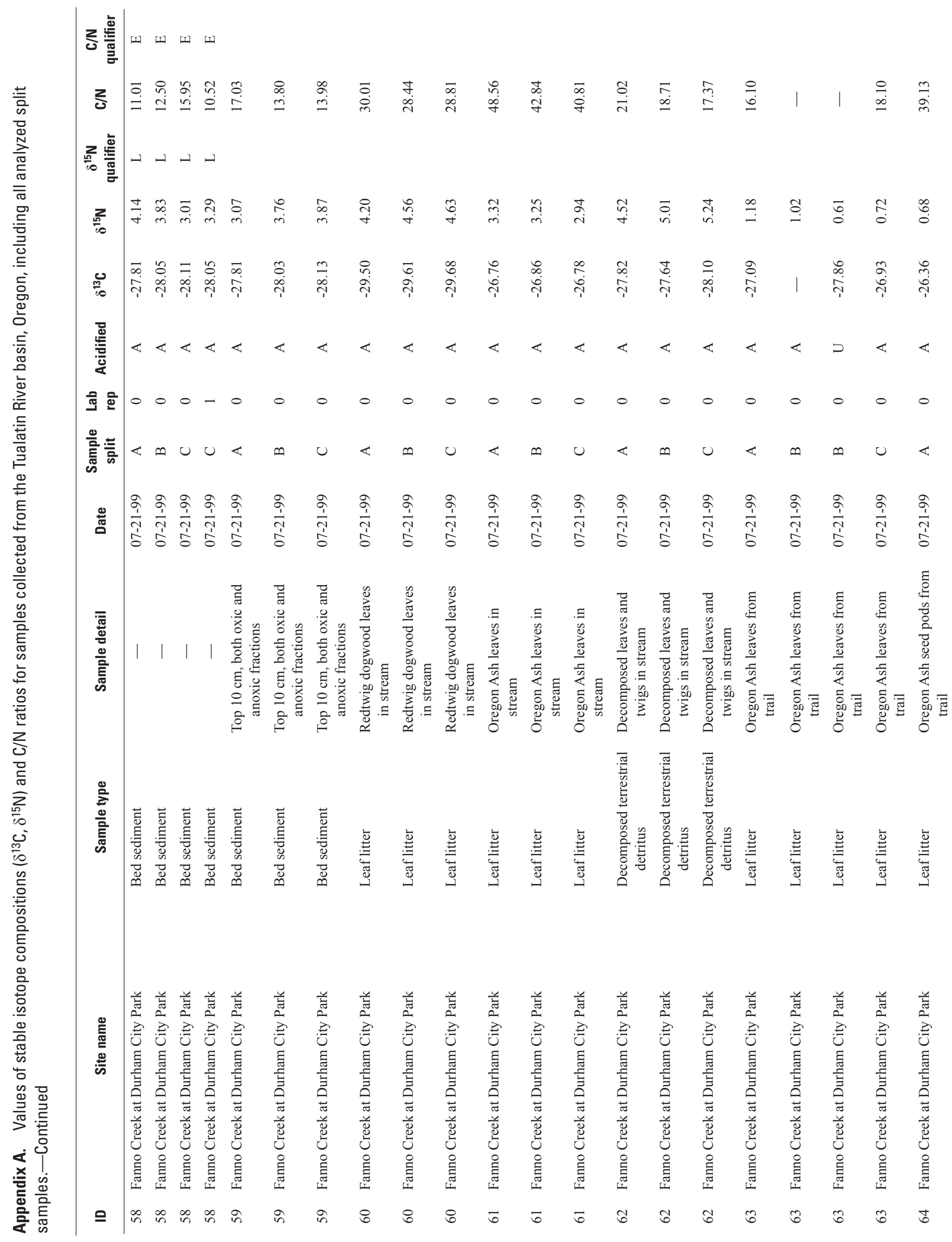




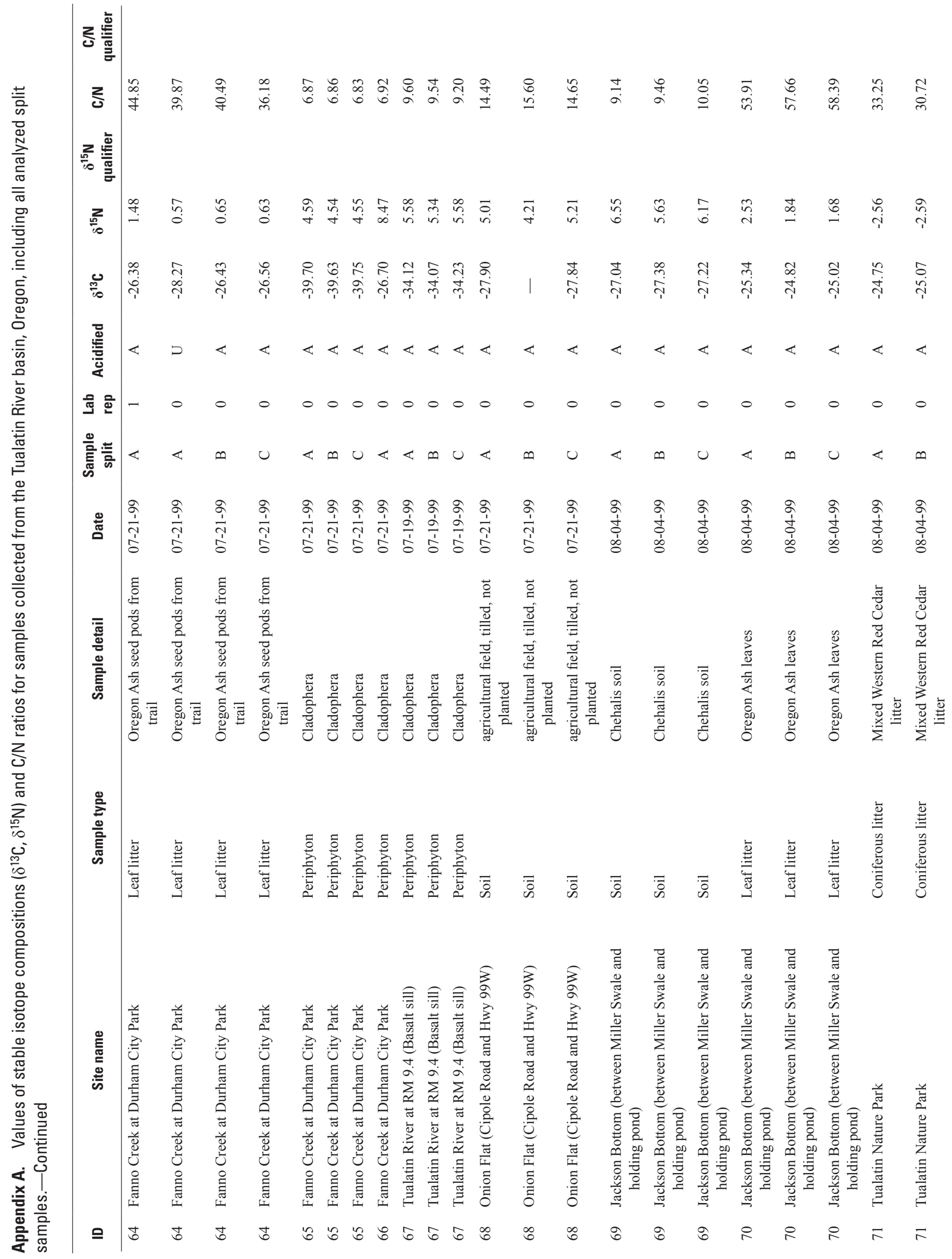




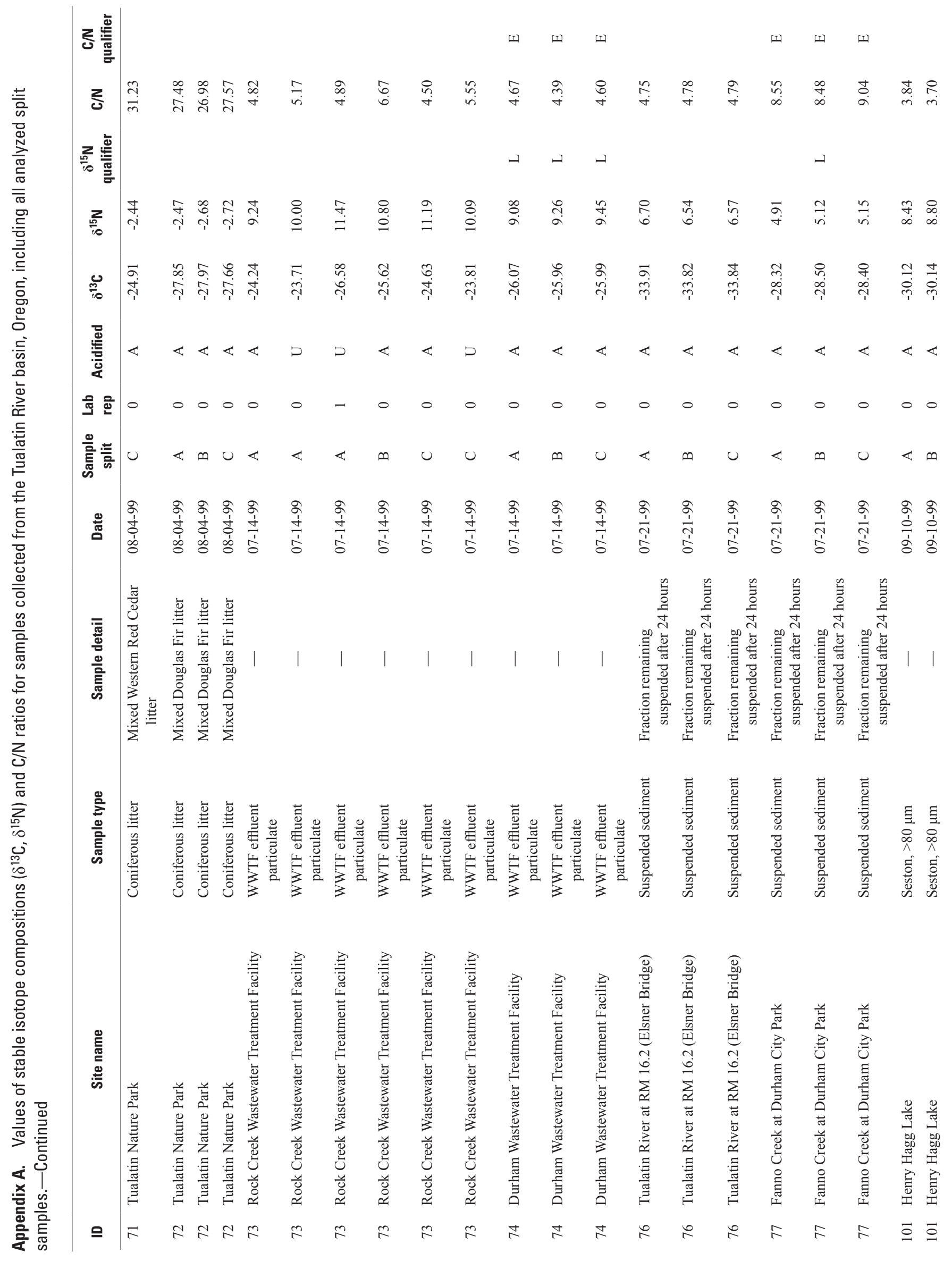




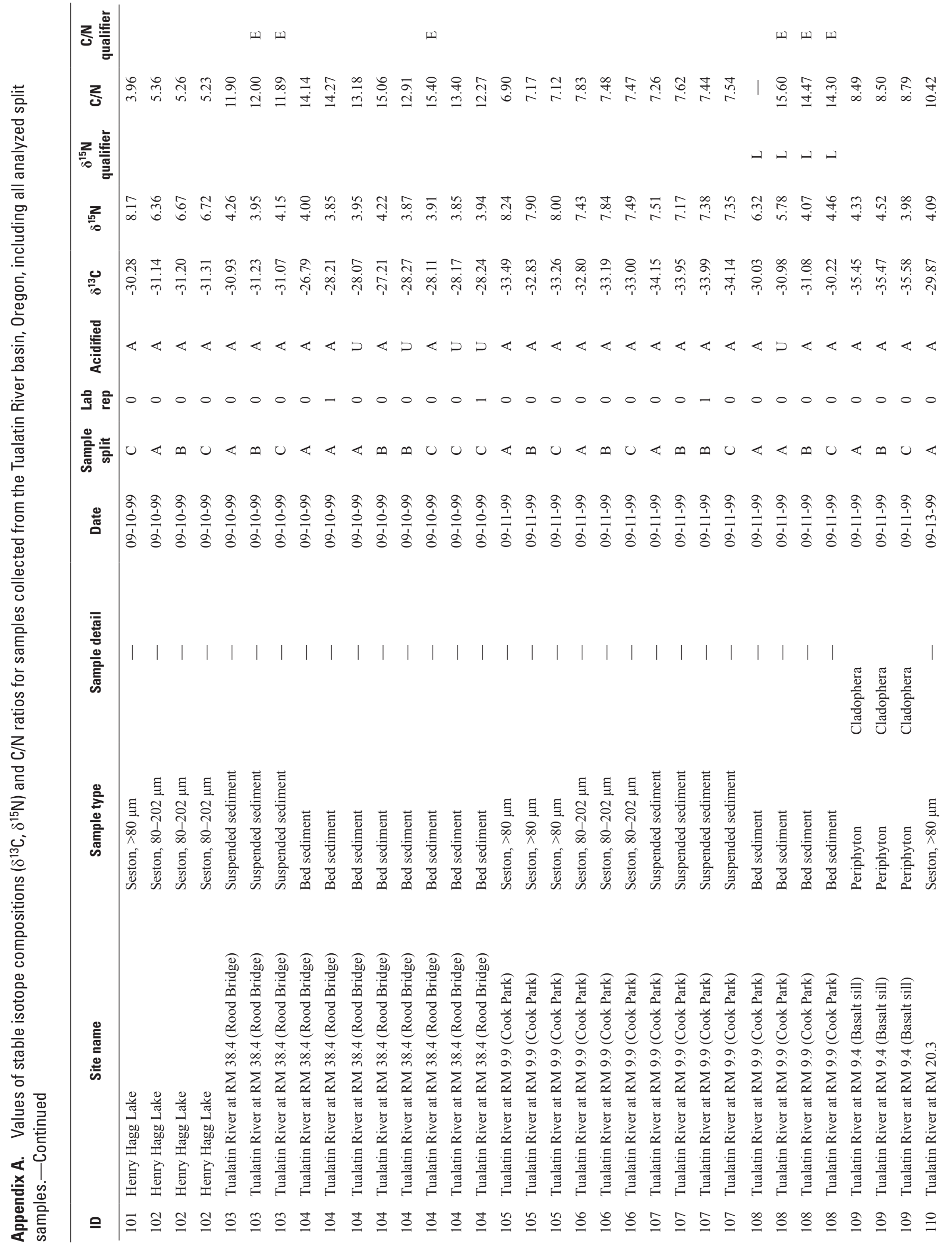




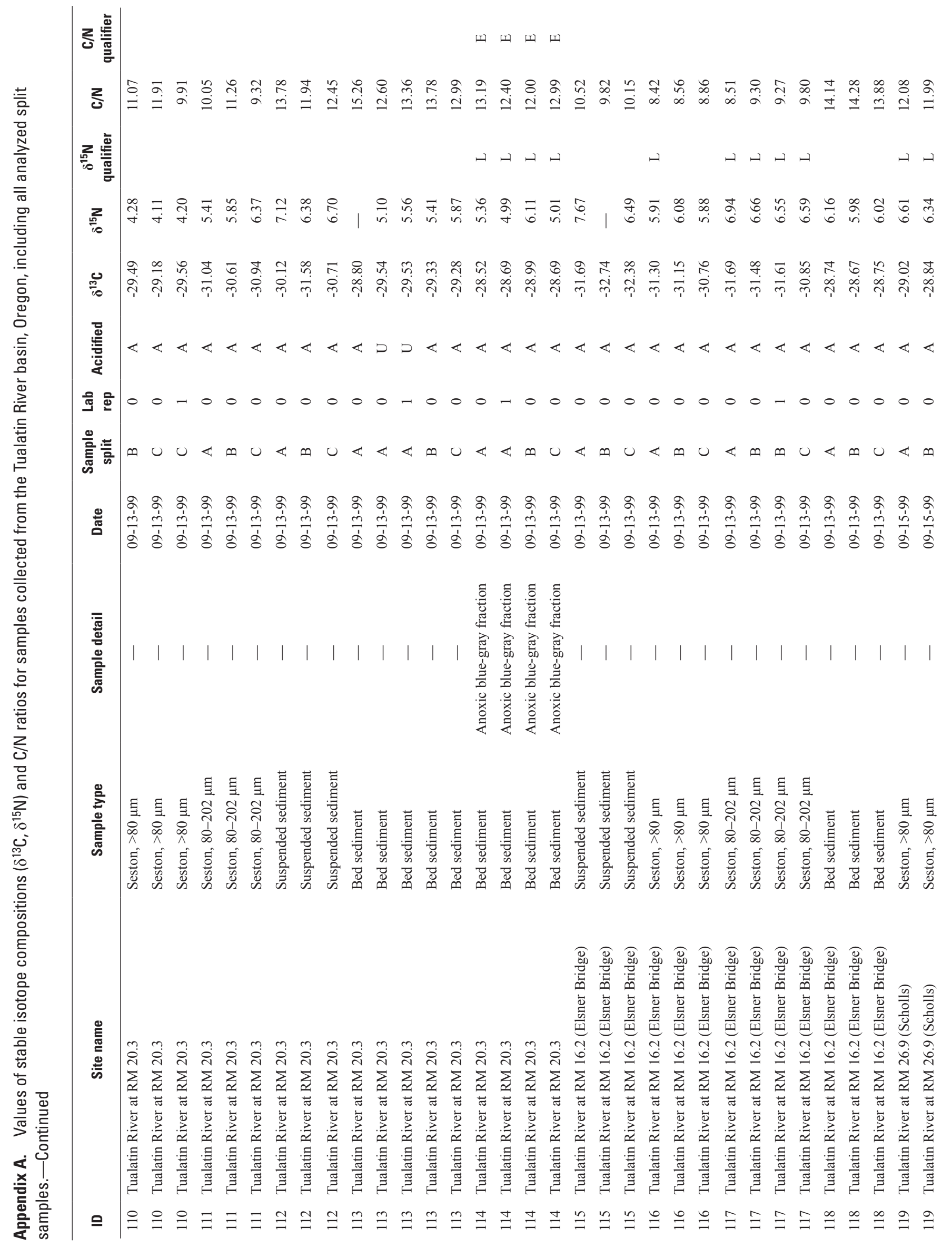




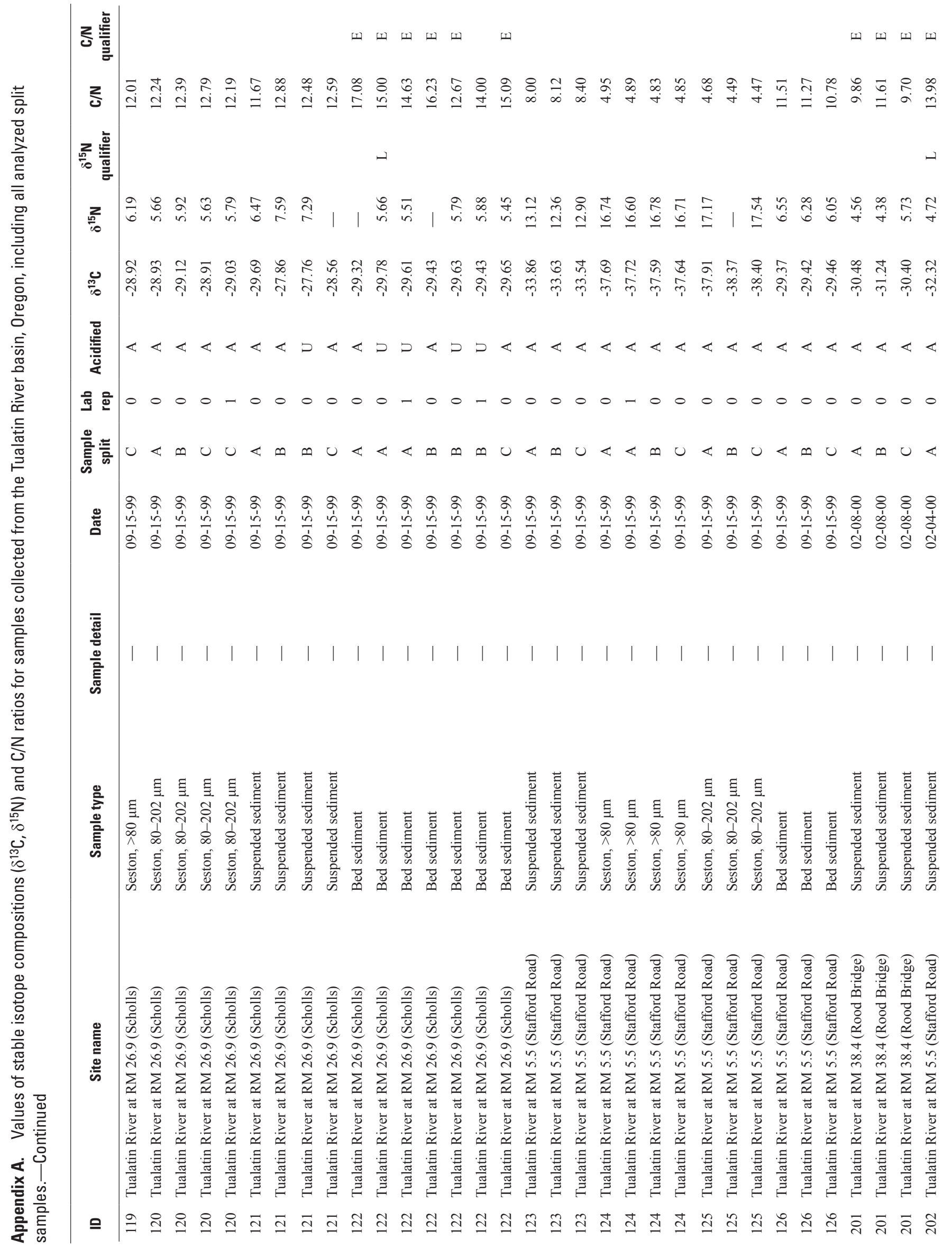




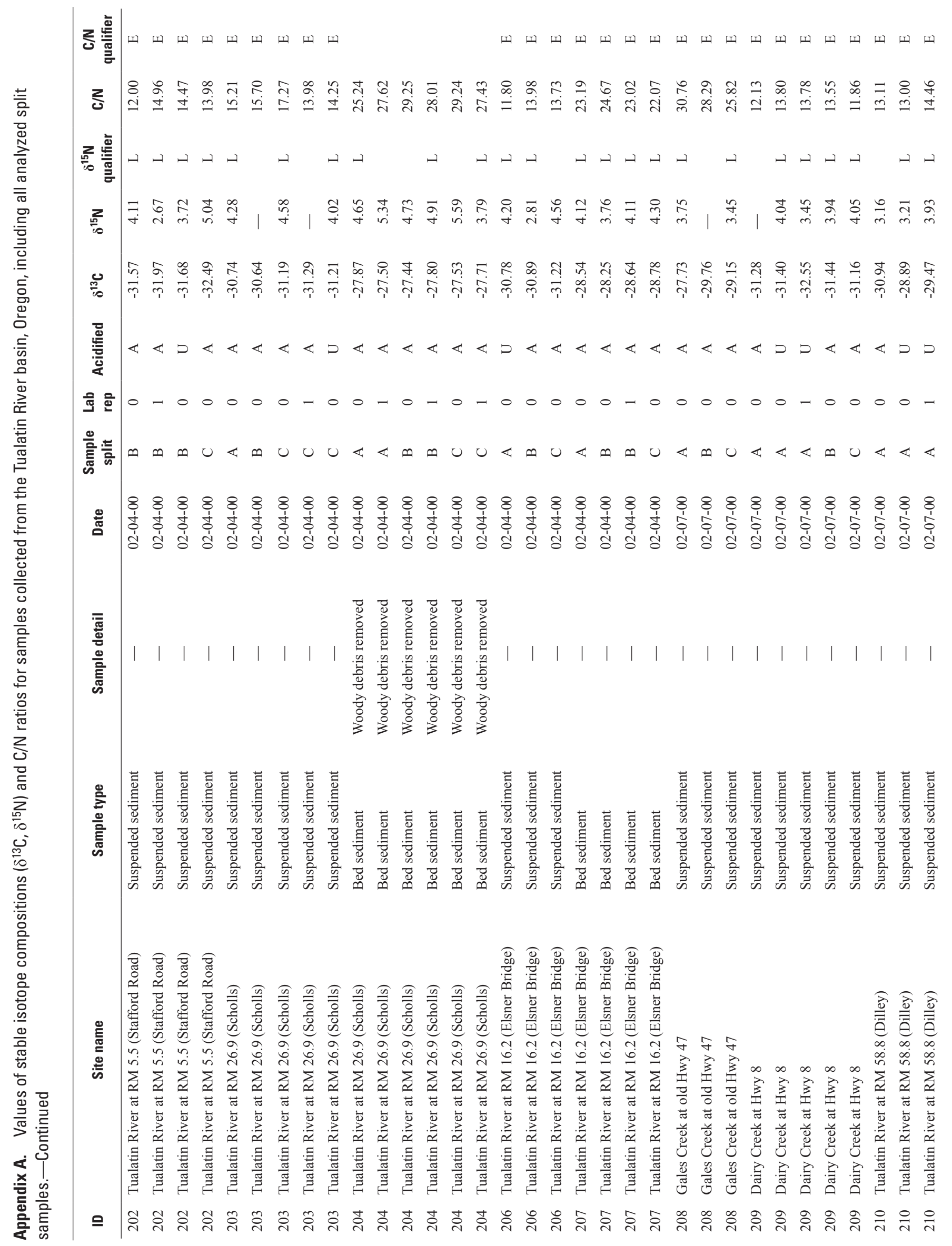




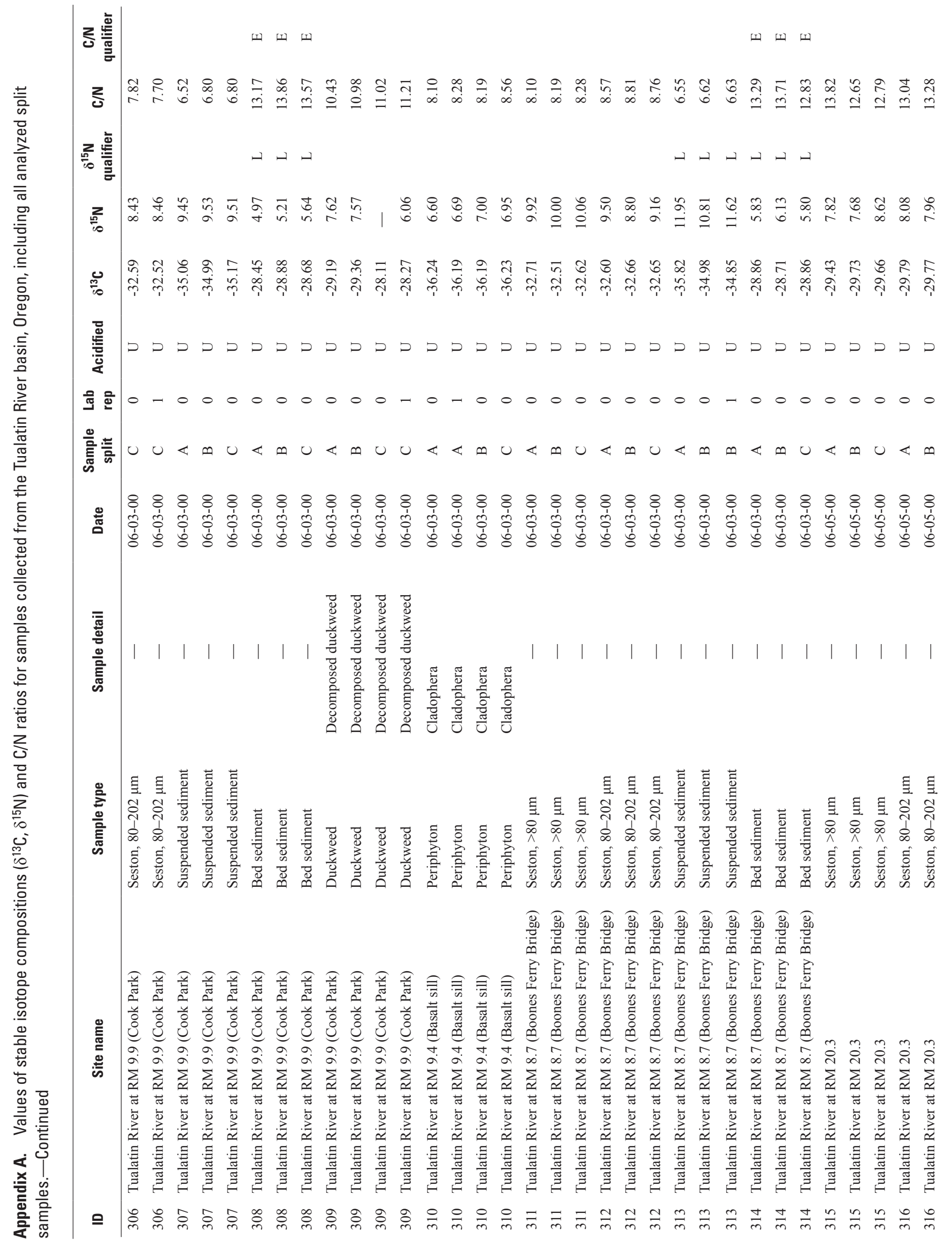




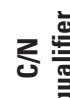

क

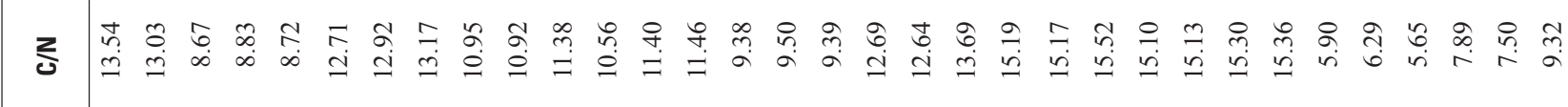

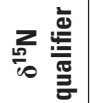

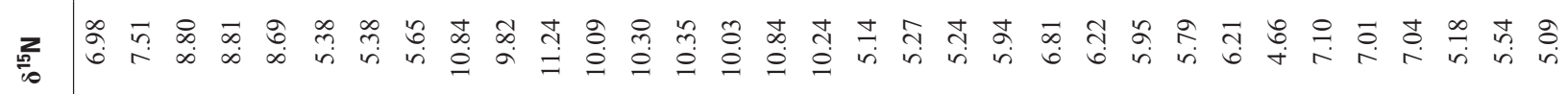

0 웃

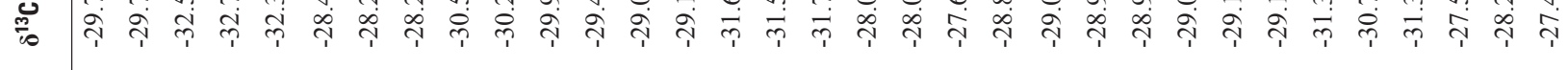

窇

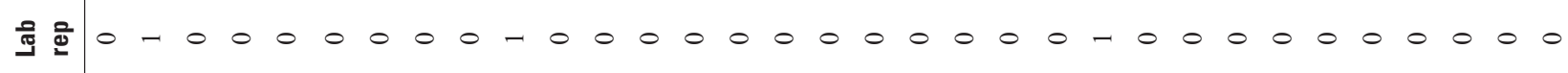

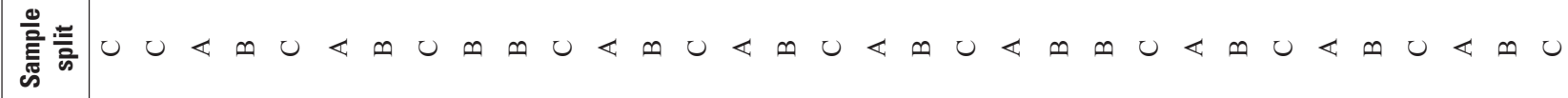

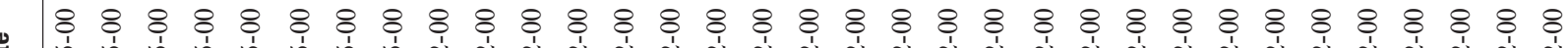

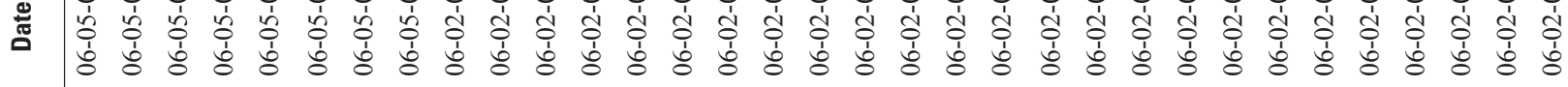

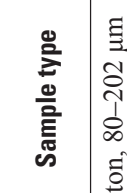

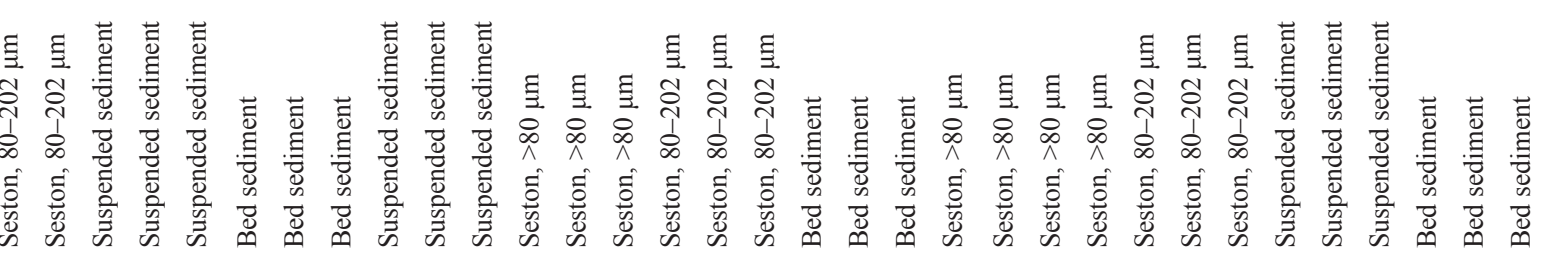

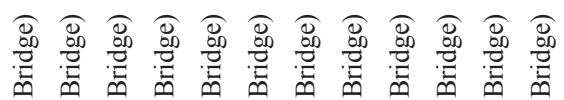

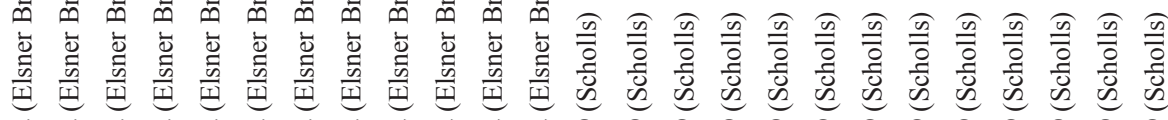

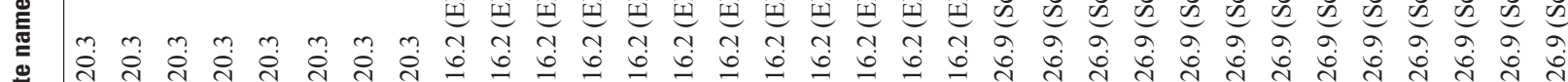

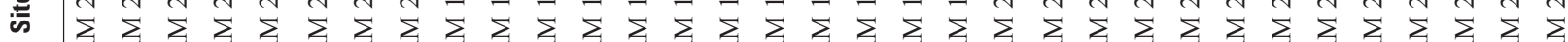

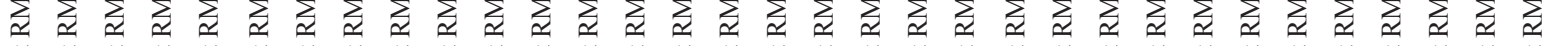
䒕

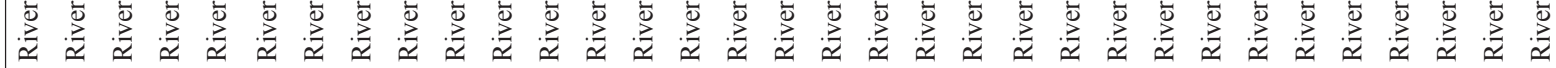

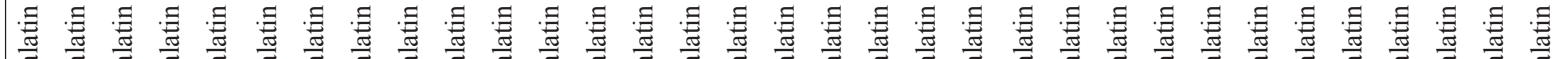

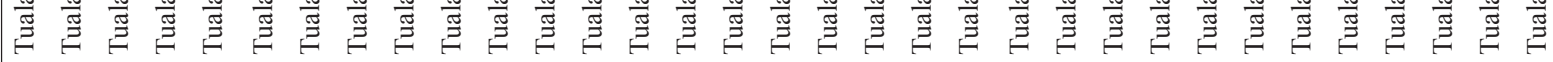

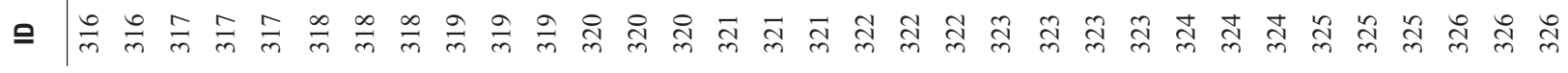




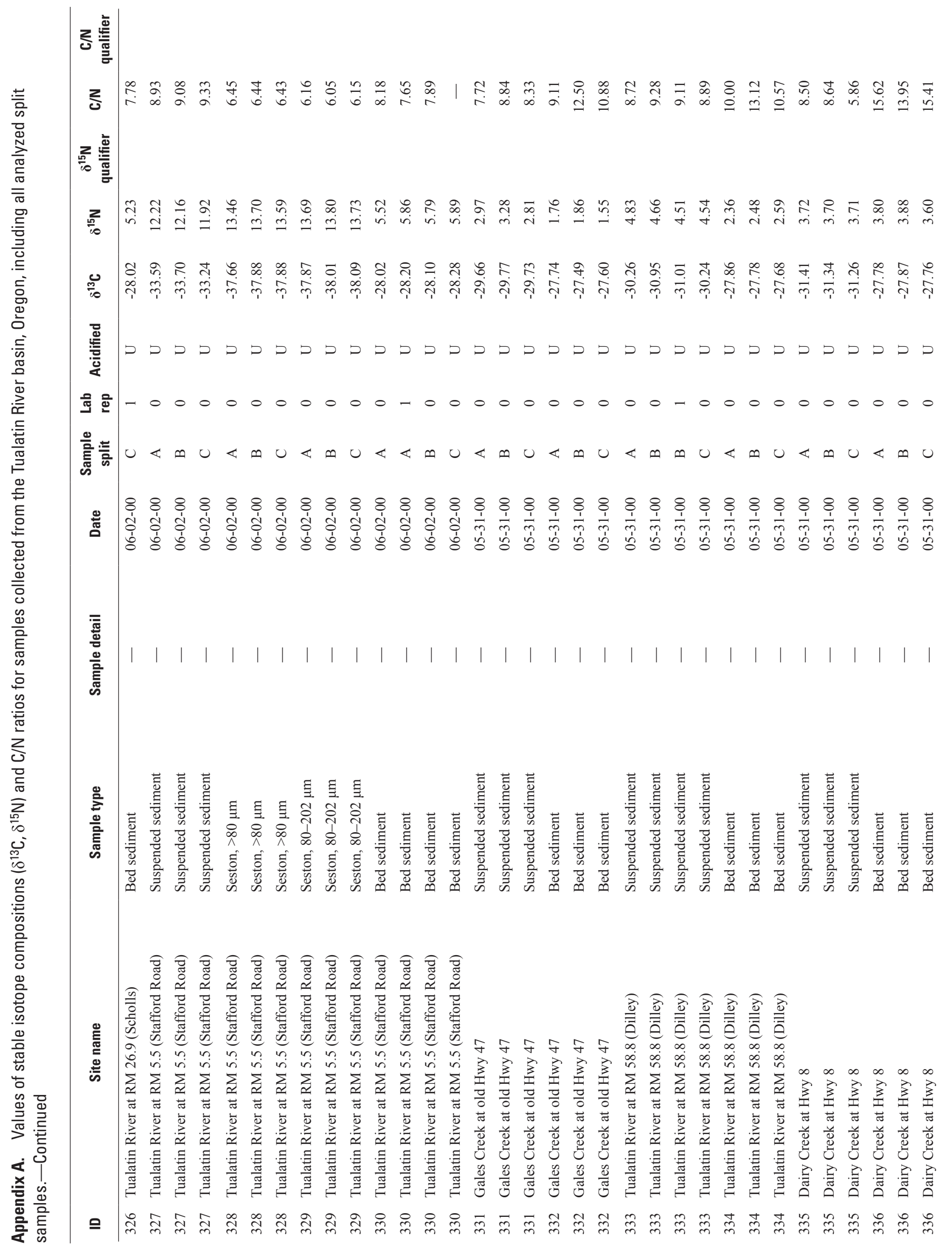




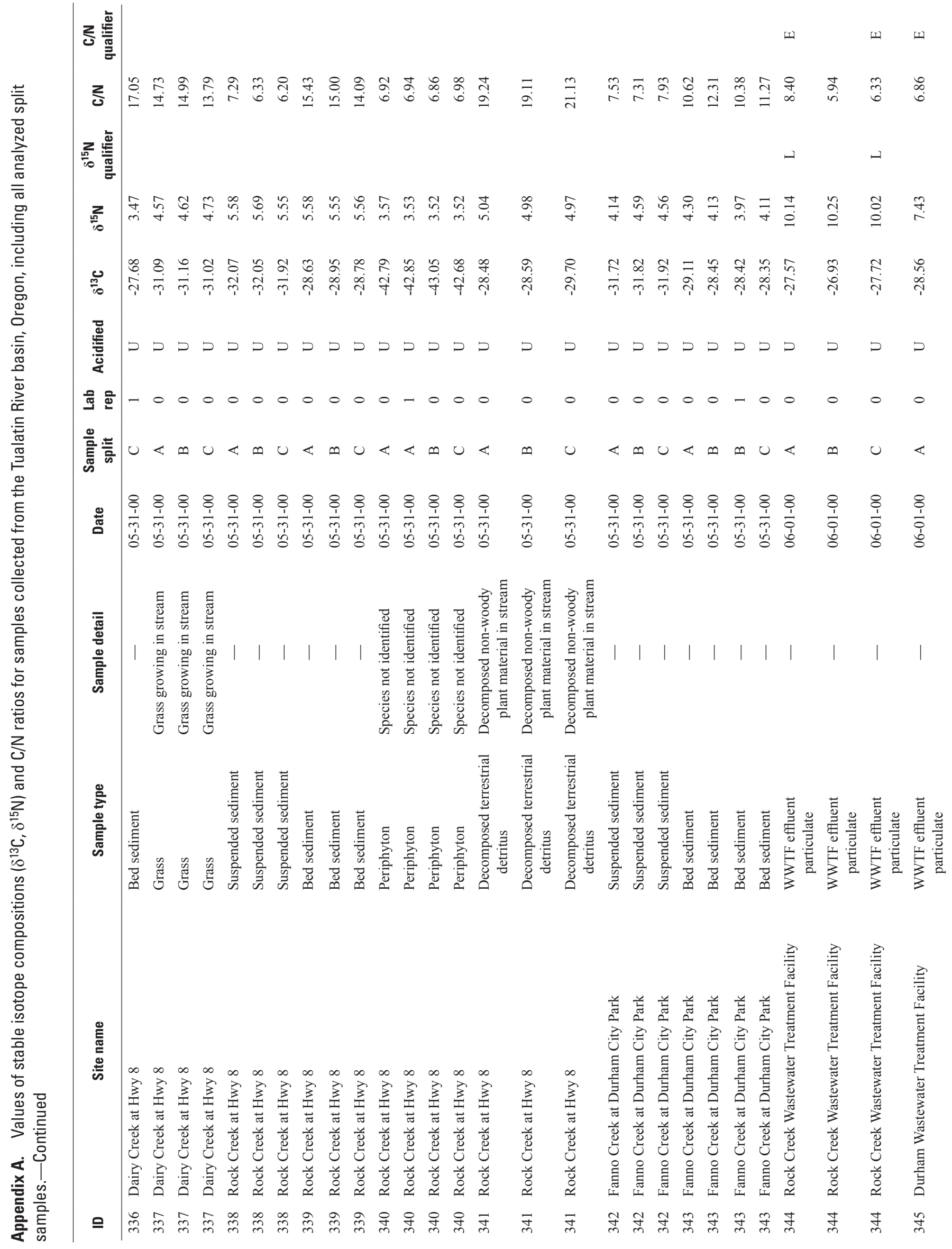




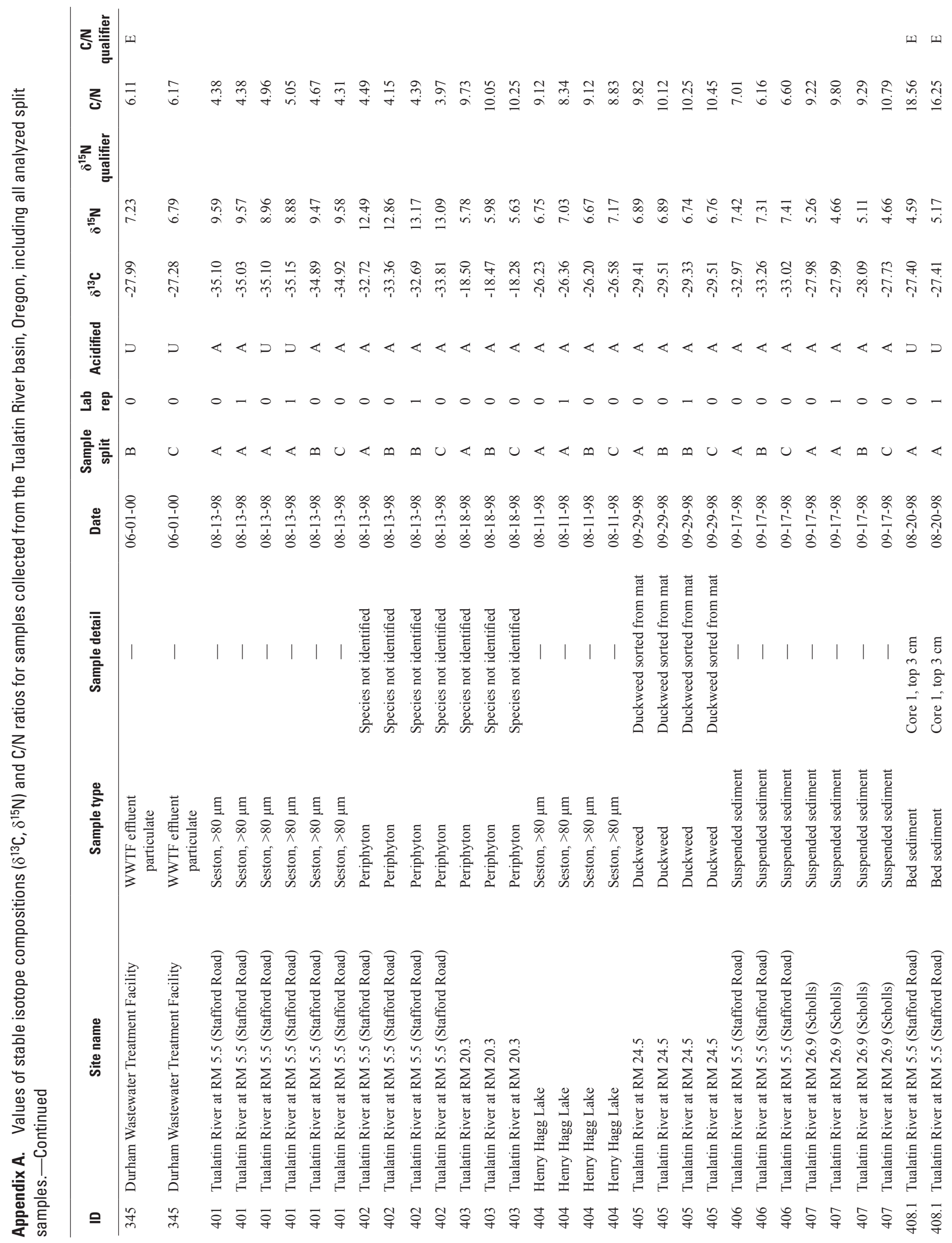




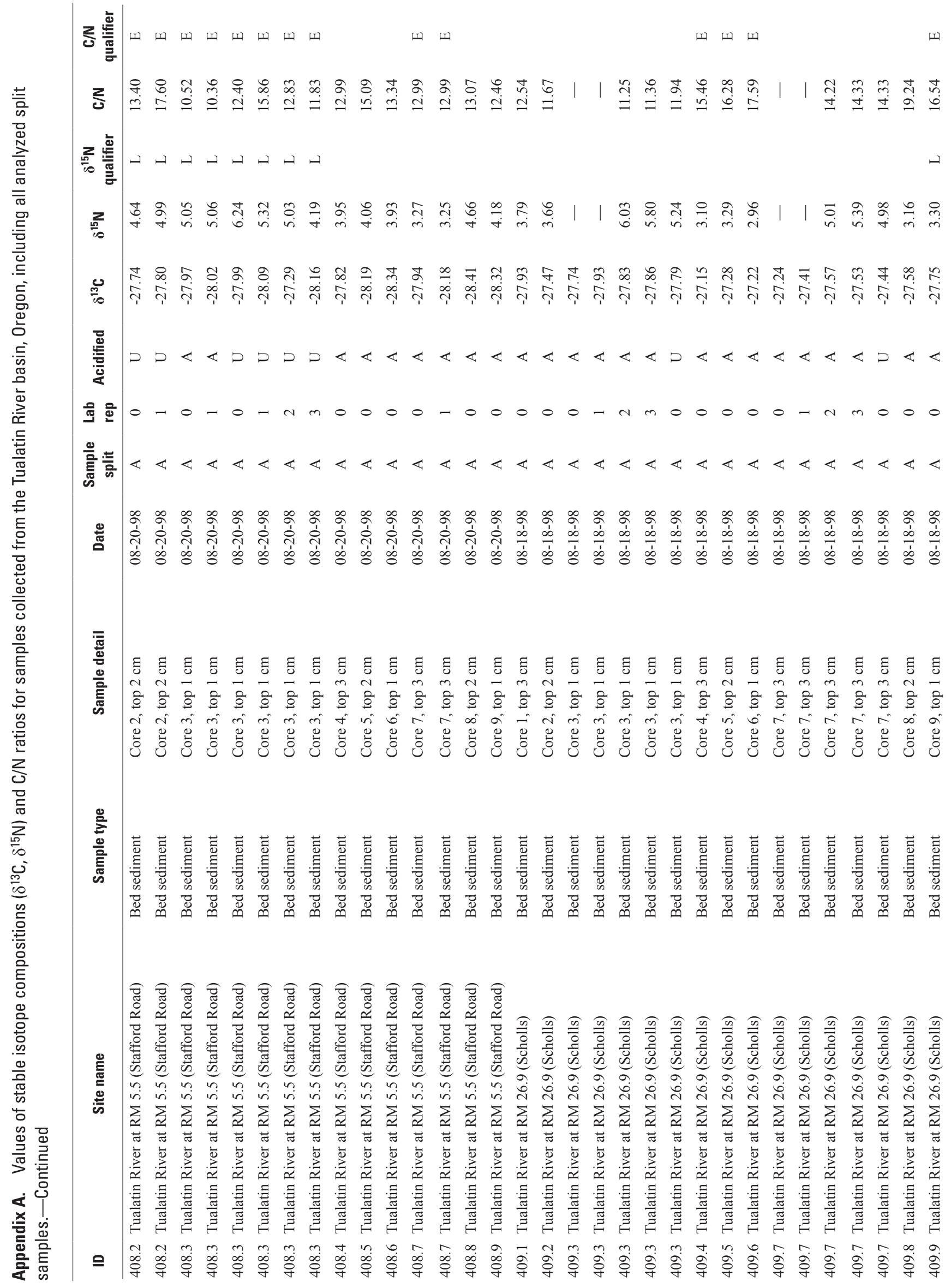




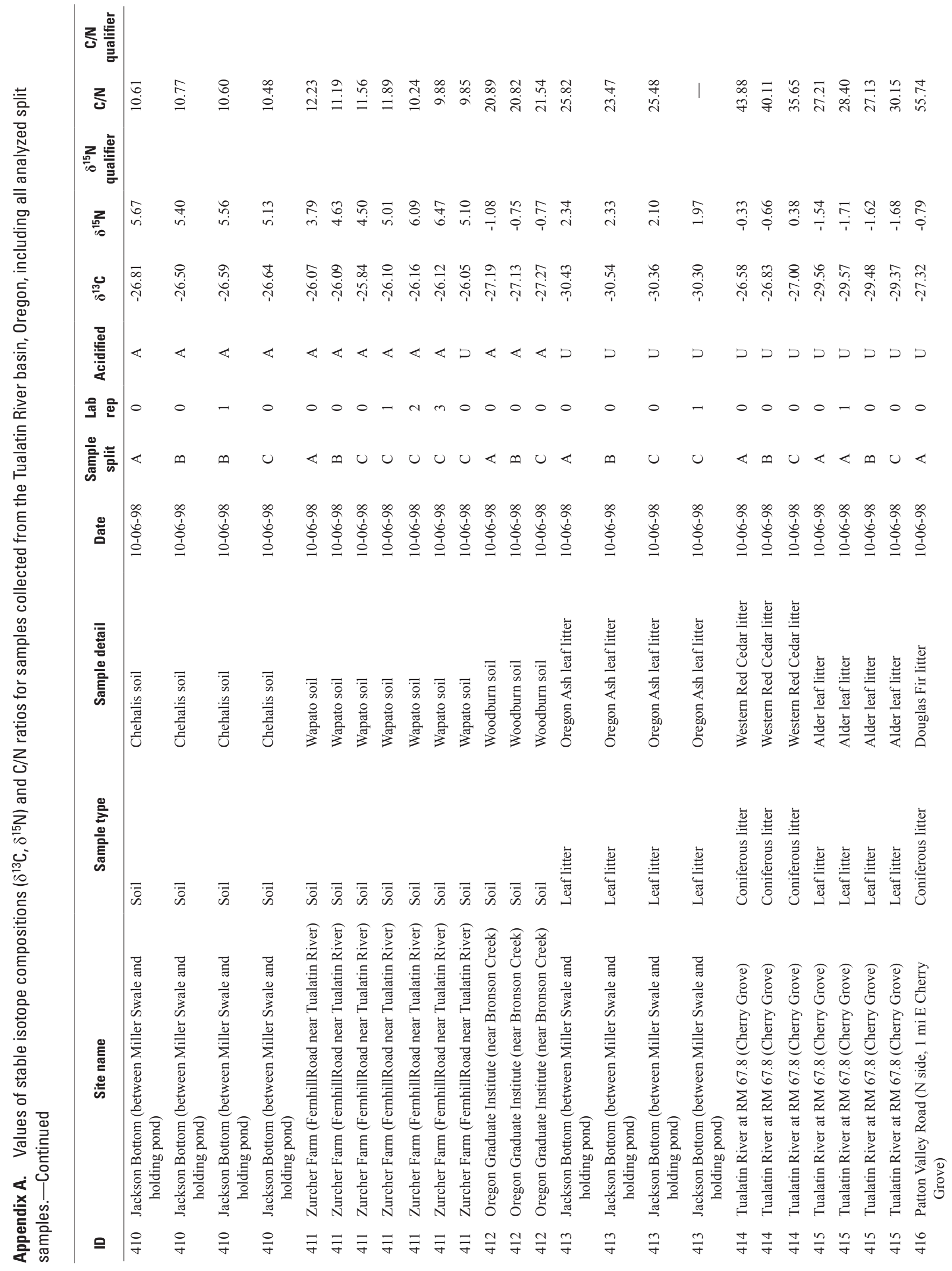




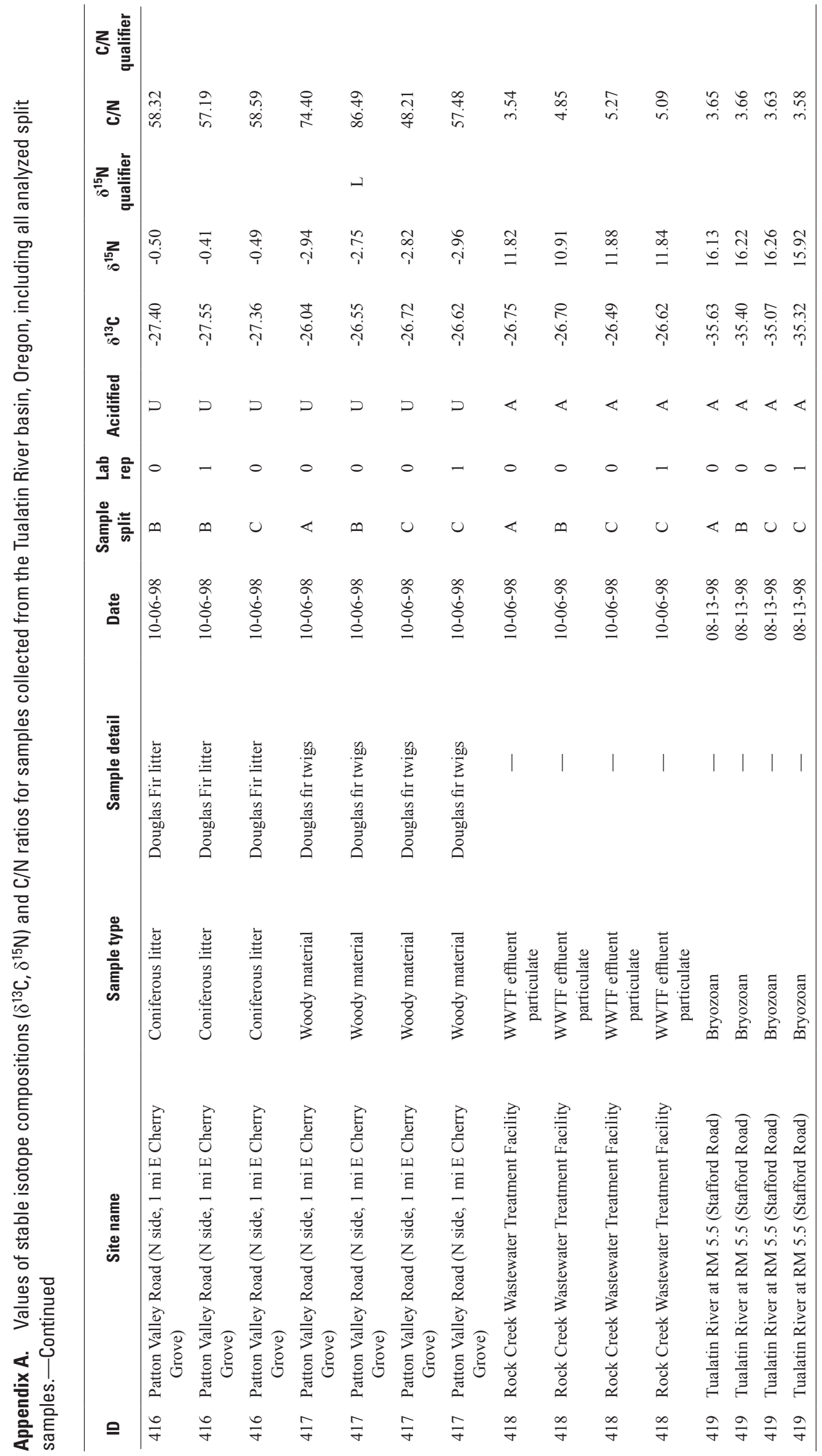


Publishing support provided by the U.S. Geological Survey

Publishing Network, Tacoma Publishing Service Center

For more information concerning the research in this report, contact the Director, Oregon Water Science Center

U.S. Geological Survey

2130 SW 5th Avenue

Portland, Oregon 97201

http://or.water.usgs.gov 


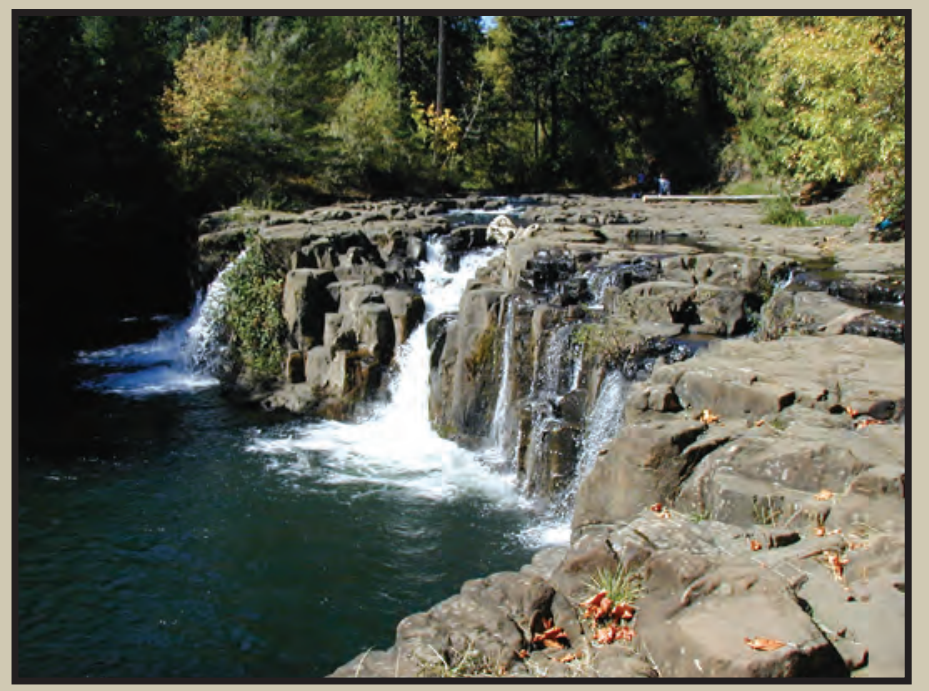

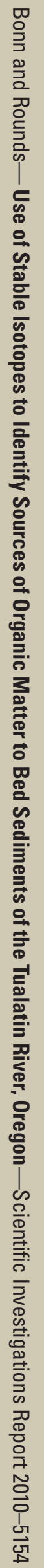

